Supplementary Materials for

\title{
Optimization of Triarylpyridinone Inhibitors of the Main Protease of SARS- CoV-2 to Low-Nanomolar Antiviral Potency
}

Chun-Hui Zhang ${ }^{1,}$, Krasimir A. Spasov ${ }^{2, \S}$, Raquel A. Reilly ${ }^{2}$, Klarissa Hollander ${ }^{2,3}$, Elizabeth A. Stone $^{1}$, Joseph A. Ippolito ${ }^{1}$, Maria-Elena Liosi ${ }^{1}$, Maya G. Deshmukh ${ }^{2,4}$, Julian Tirado-Rives ${ }^{1}$, Shuo Zhang ${ }^{5}$, Zhuobin Liang ${ }^{6}$, Scott J. Miller ${ }^{1}$, Farren Isaacs ${ }^{6}$, Brett D. Lindenbach ${ }^{5}$, Karen S. Anderson $^{2,3} \dagger$, William L. Jorgensen ${ }^{1} \dagger$

${ }^{1}$ Department of Chemistry, Yale University, New Haven, CT 06520-8107, USA. ${ }^{2}$ Department of Pharmacology, Yale University School of Medicine, New Haven, CT 06520-8066. ${ }^{3}$ Department of Molecular Biophysics and Biochemistry, Yale University School of Medicine, New Haven, CT 06520-8066. ${ }^{4}$ M.D.-Ph.D. Program. ${ }^{5}$ Department of Microbial Pathogenesis, Yale University School of Medicine, New Haven, CT 06536-0812. ${ }^{6}$ Department of Molecular, Cellular, and Developmental Biology, Yale University School of Medicine, New Haven, CT 06520-8066.

$\S$ These authors contributed equally to this work.

† Corresponding authors. Email: karen.anderson@yale.edu; william.jorgensen@yale.edu 


\section{Table of Contents}

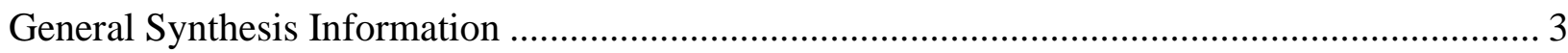

Synthesis of SARS-CoV-2 M $\mathrm{M}^{\mathrm{pro}}$ Inhibitors .................................................................... 4

Assessment of Antiviral Activity Against SARS-CoV-2 and Cellular Cytotoxicity .................. 23

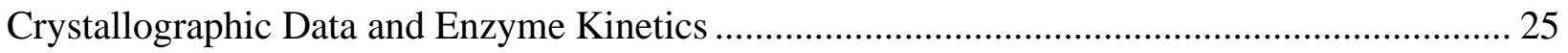

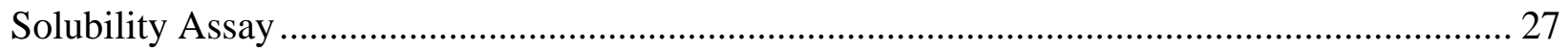

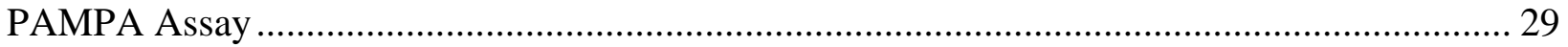

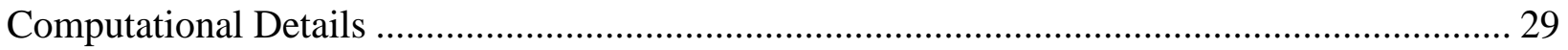

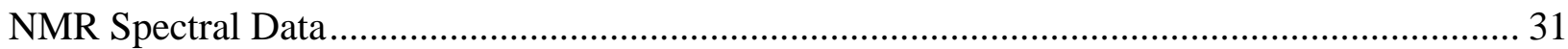

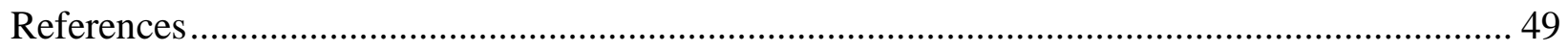




\section{General Synthesis Information}

All reactions were carried out under ambient atmosphere unless otherwise noted. Room temperature ( $\mathrm{rt}$ ) is defined as $21-23{ }^{\circ} \mathrm{C}$. Acetonitrile $(\mathrm{MeCN})$, dichloromethane (DCM), Tetrahydrofuran (THF), N,N-dimethylformamide (DMF), and toluene (PhMe) were dried over alumina and dispensed under argon from a Glass Contour Seca Solvent Purification System. All reagents were obtained from commercial sources and used without further purification. Deionized water was used for reactions, extraction solutions, and reverse-phase chromatography. All other solvents used for chromatography were HPLC grade.

Column chromatography was carried out on silica gel (300 - 400 mesh) unless otherwise specified. If specified, flash chromatography was performed using a Biotage Isolera One purification system equipped with a 10, 25, 50, or $100 \mathrm{~g}$ SNAP Ultra (HP Sphere, $25 \mu \mathrm{m}$ silica) cartridge for normal-phase column chromatography, and 12, 30, 60, or 120 g SNAP-C18 columns for reverse-phase column chromatography. Analytical thin-layer chromatography (TLC) was performed using $60 \AA$ Silica Gel $\mathrm{F}_{254}$ pre-coated plates $(0.25 \mathrm{~mm}$ thickness $)$. TLC plates were visualized by irradiation with a UV lamp. Lyophilization was conducted on a Labconco FreeZone 4.5L -84C Benchtop Freeze Dryer (Kansas City, MO, USA).

All final compounds were purified to $>95 \%$ purity, as determined by high-performance liquid chromatography (HPLC). HPLC analysis was performed using an Agilent 1260 Infinity II HPLC system with the use of a Agilent prep-C18 scalar reversed-column $(4.6 \mathrm{~mm} \times 100 \mathrm{~mm}, 5$ $\mu \mathrm{m})$. The binary solvent system was $0.1 \%$ formic acid in water (A) and acetonitrile (B), and eluted in a gradient manner from 5\% to $100 \%(\mathrm{~A} / \mathrm{B})$ in 15 minutes. The absorbance was detected at 254 $\mathrm{nm}$, and the flow rate was $1.5 \mathrm{~mL} / \mathrm{min}$.

High-resolution mass spectrometry (HRMS) was conducted by the Chemical and Biophysical Instrumentation Center in the Chemistry Department at Yale University using a Waters Xevo Q-TOF high-resolution mass spectrometer using electrospray ionization (ESI). For routine data analysis, ultra high-performance liquid chromatography-mass spectrometry (UPLC/MS) was performed with a Waters Acquity UPLC/MS instrument equipped with a reversed-phase BEH C18 column (1.7 mm particle size, 2.1 x $50 \mathrm{~mm}$ ), a dual atmospheric pressure chemical ionization (API)/electrospray ionization (ESI) mass spectrometry detector, and a photodiode array detector. An Advion Express mass spectrometer (Ithaca, NY, USA) was also used for routine mass spectral (MS or TLC/MS) analysis.

Routine ${ }^{1} \mathrm{H}$ NMR spectra were recorded on Agilent 400, 500 or $600 \mathrm{MHz}$ spectrometers at ambient temperature unless otherwise stated. NMR solvents, chloroform- $d\left(\mathrm{CDCl}_{3}\right)$, dimethyl suloxide- $d_{6}$ (DMSO- $\left.d_{6}\right)$ and methanol- $d_{4}\left(\mathrm{CD}_{3} \mathrm{OD}\right)$ were purchased from Cambridge Isotope Laboratories and used without further purification. $\mathrm{CDCl}_{3}$ was stored at ambient temperature over $4 \AA$ molecular sieves, and fresh DMSO- $d_{6}$ and $\mathrm{CD}_{3} \mathrm{OD}$ ampules were used immediately after opening. Spectra were processed using MestReNova 10.0.1 using the automatic phasing and 
polynomial baseline correction capabilities. Splitting was determined using the automatic multiplet analysis function with intervention as necessary. Spectral data are reported as follows: chemical shift (multiplicity [singlet (s), broad singlet (bs), doublet (d), triplet (t), quartet (q), pentet (p), multiplet (m), doublet of doublets (dd), doublet of doublet of doublets (ddd), doublet of triplet of doublets (dtd), doublet of doublet of doublet of doublets (dddd), doublet of triplets (dt), triplet of doublets (td), complex (comp), etc.], coupling constant (Hz), integration). Chemical shifts are reported in ppm ( $\delta$ ), and coupling constants are reported in $\mathrm{Hz} .{ }^{1} \mathrm{H}$ Resonances are referenced to solvent residual peaks for $\mathrm{CDCl}_{3}$ (7.26 ppm), DMSO- $d_{6}(2.50), \mathrm{CD}_{3} \mathrm{OD}$ (3.31 ppm) or TMS (0 ppm). Routine ${ }^{13} \mathrm{C}$ NMR spectra were recorded on Agilent 400,500 or $600 \mathrm{MHz}$ spectrometers with protons fully decoupled. ${ }^{13} \mathrm{C}$ Resonances are reported in ppm relative to solvent residual peaks for $\mathrm{CDCl}_{3}(77.2 \mathrm{ppm})$ DMSO- $d_{6}(39.5)$, or $\mathrm{CD}_{3} \mathrm{OD}(49.0 \mathrm{ppm}) .{ }^{19} \mathrm{~F}-\mathrm{NMR}$ spectra were recorded on Agilent 400 or $500 \mathrm{MHz}$ spectrometers without proton decoupling.

\section{Synthesis of SARS-CoV-2 M ${ }^{\text {pro }}$ Inhibitors ${ }^{1}$}

\section{2-(Benzyloxy)-5-bromopyridine (S2)}

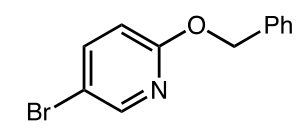

Benzyl alcohol (6.75 g, $62.48 \mathrm{mmol}, 1.1 \mathrm{eq})$ was dissolved in anhydrous THF $(120 \mathrm{~mL})$ and cooled to $0{ }^{\circ} \mathrm{C}$. Then, $60 \%$ sodium hydride $(2.73 \mathrm{~g}, 68.2 \mathrm{mmol}$, $1.2 \mathrm{eq})$ was added and stirred for $30 \mathrm{~min}$ at $0{ }^{\circ} \mathrm{C}$. Next, 5-bromo-2fluoropyridine ( $10 \mathrm{~g}, 56.8 \mathrm{mmol}, 1.0 \mathrm{eq})$ was added and the mixture was heated at $70^{\circ} \mathrm{C}$ overnight. The reaction was quenched by the dropwise addition of water, then brine and more ethyl acetate were added for extraction. The organic layer was dried over $\mathrm{Na}_{2} \mathrm{SO}_{4}$ and the solvent removed under reduced pressure, the residue was recrystallized in hexane to afford a white solid ( $12 \mathrm{~g}, 80 \%$ yield). ${ }^{1} \mathbf{H}$ NMR $\left(400 \mathrm{MHz}, \mathrm{CDCl}_{3}\right) \delta 8.21(\mathrm{~d}, J=2.3 \mathrm{~Hz}, 1 \mathrm{H}), 7.65(\mathrm{dd}, J=8.8,2.5 \mathrm{~Hz}, 1 \mathrm{H}), 7.44(\mathrm{~d}, J$ $=7.2 \mathrm{~Hz}, 2 \mathrm{H}), 7.39-7.30(\mathrm{~m}, 3 \mathrm{H}), 6.72(\mathrm{~d}, J=8.8 \mathrm{~Hz}, 1 \mathrm{H}), 5.34(\mathrm{~s}, 2 \mathrm{H}) . \mathbf{M S}(\mathrm{ESI}) \mathrm{m} / z:[\mathrm{M}+\mathrm{H}]^{+}$ calcd for $\mathrm{C}_{12} \mathrm{H}_{11} \mathrm{BrNO}^{+} 264.00$, found 264.0, 266.0.

\section{5-(6-(Benzyloxy)pyridin-3-yl)-2,4-dimethoxypyrimidine (S3)}

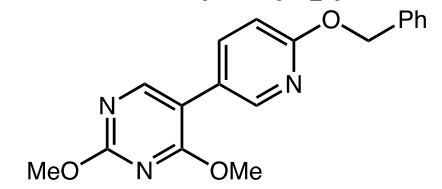

To a $250 \mathrm{~mL}$ round bottom flask, 2-(benzyloxy)-5-bromopyridine ( $\mathbf{S 2}$,

$7 \mathrm{~g}, 26.5 \mathrm{mmol}, 1.0 \mathrm{eq}),(2,4$-dimethoxypyrimidin-5-yl) boronic acid (6.34 g, $34.45 \mathrm{mmol}, 1.3 \mathrm{eq}), \mathrm{Cs}_{2} \mathrm{CO}_{3}(17.3 \mathrm{~g}, 53 \mathrm{mmol}, 2.0 \mathrm{eq})$ and bis(triphenylphosphine)-palladium(II) chloride ( $0.93 \mathrm{~g}, 1.3 \mathrm{mmol}, 0.05$

eq) were added and suspended in DMF $(150 \mathrm{~mL})$. The mixture underwent three cycles of vacuum/filling with $\mathrm{N}_{2}$, then stirred at $80^{\circ} \mathrm{C}$ for $5 \mathrm{~h}$. The mixture was concentrated in vacuo and the residue was resuspended in water $(80 \mathrm{~mL})$ and extracted with dichloromethane $(2 \times 80 \mathrm{~mL})$. The combined organic layer was concentrated in vacuo and the crude product was purified using silica gel chromatography with an ethyl acetate/hexanes gradient $(0-10 \%)$ to afford a white solid (6.2 g, 72\% yield). ${ }^{1} \mathbf{H}$ NMR (400 MHz, $\left.\mathrm{CDCl}_{3}\right) \delta 8.28(\mathrm{~s}, 1 \mathrm{H}), 8.24(\mathrm{~s}, 1 \mathrm{H}), 7.75(\mathrm{~d}, J=8.6 \mathrm{~Hz}$, $1 \mathrm{H}), 7.48(\mathrm{~d}, J=7.7 \mathrm{~Hz}, 2 \mathrm{H}), 7.39$ (t, $J=7.3 \mathrm{~Hz}, 2 \mathrm{H}), 7.34$ (d, $J=6.6 \mathrm{~Hz}, 1 \mathrm{H}), 6.88(\mathrm{~d}, J=8.6$ 
$\mathrm{Hz}, 1 \mathrm{H}), 5.42(\mathrm{~s}, 2 \mathrm{H}), 4.04(\mathrm{~s}, 3 \mathrm{H}), 4.03(\mathrm{~s}, 3 \mathrm{H}) . \mathbf{M S}(\mathrm{ESI}) \mathrm{m} / z$ : $[\mathrm{M}+\mathrm{H}]^{+}$calcd for $\mathrm{C}_{18} \mathrm{H}_{18} \mathrm{~N}_{3} \mathrm{O}_{3}{ }^{+}$ 324.13 , found 324.2 .

\section{5-(2,4-Dimethoxypyrimidin-5-yl)pyridin-2(1H)-one (S4)}

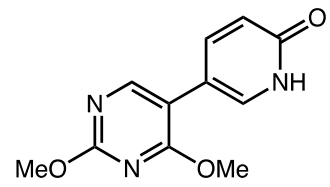

To a $250 \mathrm{~mL}$ round bottom flask, 5-(6-(benzyloxy)pyridin-3-yl)-2,4dimethoxypyrimidine (S3, $6.2 \mathrm{~g})$ and palladium on activated carbon $(10 \%$, $500 \mathrm{mg})$ were suspended in methanol $(150 \mathrm{~mL})$ and water $(10 \mathrm{~mL})$. The mixture underwent 3 cycles of vacuum/filling with $\mathrm{H}_{2}$ and then stirred at

$40{ }^{\circ} \mathrm{C}$ for $4 \mathrm{~h}$. After the reaction was complete, dichloromethane was added to dissolve the solid product, then the mixture was filtered. The filtrate was concentrated in vacuo to give the desired product as a gray solid (4.4 g, 99\% yield). ${ }^{1} \mathbf{H}$ NMR $\left(400 \mathrm{MHz}, \mathrm{CDCl}_{3}\right) \delta 13.21$ (br.s, $\left.1 \mathrm{H}\right), 8.20$ (s, $1 \mathrm{H}), 7.67$ (dd, $J=9.4,2.6 \mathrm{~Hz}, 1 \mathrm{H}), 7.63(\mathrm{~d}, J=2.2 \mathrm{~Hz}, 1 \mathrm{H}), 6.67$ (d, $J=9.4 \mathrm{~Hz}, 1 \mathrm{H}), 4.04$ (s, 3H), $4.03\left(\mathrm{~s}, 3 \mathrm{H}\right.$ ). MS (ESI) $m / z$ : $[\mathrm{M}+\mathrm{H}]^{+}$calcd for $\mathrm{C}_{11} \mathrm{H}_{12} \mathrm{~N}_{3} \mathrm{O}_{3}{ }^{+} 234.09$, found 234.1.

\section{5-(2,4-Dimethoxypyrimidin-5-yl)-2H-[1,3'-bipyridin]-2-one (S5)}

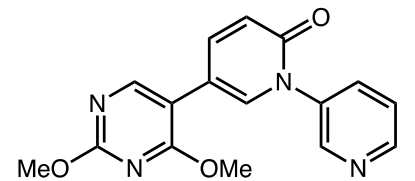

To a $250 \mathrm{~mL}$ round bottom flask, 5-(2,4-Dimethoxypyrimidin-5yl)pyridin-2(1H)-one (S4, $4.4 \mathrm{~g}, 18.9 \mathrm{mmol}, 1.0 \mathrm{eq}), 3$-pyridylboronic acid (4.65 g, $37.8 \mathrm{mmol}, 2.0 \mathrm{eq})$, cupric acetate $(3.43 \mathrm{~g}, 18.9 \mathrm{mmol}, 1.0$ eq) and $N, N, N^{\prime}, N^{\prime}$-Tetramethylethylenediamine (4.4 g, $37.8 \mathrm{mmol}, 2.0$ eq) were suspended in anhydrous DMF $(120 \mathrm{~mL})$. Dry air was bubbled through the mixture and the solution was then stirred at room temperature for 4 days. After the reaction was complete, the mixture was concentrated in vacuo and the residue was diluted with aq. ammonium $(5 \%, 40 \mathrm{~mL})$ and the organic layer was extracted with dichloromethane $(3 \times 40 \mathrm{~mL})$. The combined organic layer was concentrated in vacuo and the crude product was purified using silica gel chromatography with a methanol/ dichloromethane gradient ( $0-5 \%)$ to yield the desired product as a white solid (4.3 g, 74\% yield) ${ }^{1} \mathbf{H}$ NMR $\left(400 \mathrm{MHz}, \mathrm{CDCl}_{3}\right) \delta 8.70(\mathrm{~s}, 2 \mathrm{H}), 8.23(\mathrm{~s}, 1 \mathrm{H}), 7.89(\mathrm{~d}, J=8.2 \mathrm{~Hz}$, $1 \mathrm{H}), 7.62(\mathrm{dd}, J=9.6,2.2 \mathrm{~Hz}, 1 \mathrm{H}), 7.54(\mathrm{~d}, J=2.5 \mathrm{~Hz}, 1 \mathrm{H}), 7.48$ (dd, $J=8.1,4.8 \mathrm{~Hz}, 1 \mathrm{H}), 6.75$ $(\mathrm{d}, J=9.6 \mathrm{~Hz}, 1 \mathrm{H}), 4.05(\mathrm{~s}, 3 \mathrm{H}), 4.03(\mathrm{~s}, 3 \mathrm{H}) . \mathbf{M S}(\mathrm{ESI}) \mathrm{m} / \mathrm{z}$ : $[\mathrm{M}+\mathrm{H}]^{+}$calcd for $\mathrm{C}_{16} \mathrm{H}_{15} \mathrm{~N}_{4} \mathrm{O}_{3}{ }^{+}$ 311.11, found 311.2.

\section{3-Bromo-5-(2,4-dimethoxypyrimidin-5-yl)-2H-[1,3'-bipyridin]-2-one (S6)}

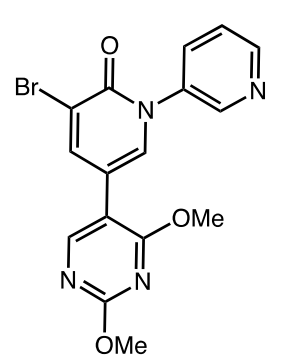

To a $250 \mathrm{~mL}$ round bottom flask, 5-(2,4-Dimethoxypyrimidin-5-yl)-2H-[1,3'bipyridin]-2-one (S5, $4.3 \mathrm{~g} 13.9 \mathrm{mmol}, 1.0 \mathrm{eq}$ ) was dissolved in anhydrous DMF $(80 \mathrm{~mL})$. The mixture underwent 3 cycles of vacuum/filling with $\mathrm{N}_{2}$, then $\mathrm{N}$ bromosuccinimide $(9.9 \mathrm{~g}, 55.6 \mathrm{mmol}, 4 \mathrm{eq})$ was added and the solution was stirred at room temperature for $4 \mathrm{~h}$. Then the reaction was quenched with aqueous sodium thiosulfate solution $(1 \mathrm{M}, 50 \mathrm{~mL})$ at $0{ }^{\circ} \mathrm{C}$ and stirred at this temperature for $2 \mathrm{~h}$. The aqueous layer was extracted with dichloromethane ( $3 \times$ $60 \mathrm{~mL}$ ) and then the combined organic layer was concentrated in vacuo at low temperature $\left(20^{\circ} \mathrm{C}\right)$. The residue was further dried using a vacuum pump, then the crude product was purified using silica gel chromatography with a methanol/ dichloromethane gradient ( 0 - $5 \%)$ to afford an orange 
solid (3.7 g, 69\% yield). ${ }^{1} \mathbf{H}$ NMR (400 MHz, $\left.\mathrm{CDCl}_{3}\right) \delta 8.72(\mathrm{~s}, 2 \mathrm{H}), 8.22(\mathrm{~s}, 1 \mathrm{H}), 8.04(\mathrm{~d}, J=2.3$ $\mathrm{Hz}, 1 \mathrm{H}), 7.95(\mathrm{~d}, J=8.2 \mathrm{~Hz}, 1 \mathrm{H}), 7.53(\mathrm{dd}, J=8.0,3.7 \mathrm{~Hz}, 2 \mathrm{H}), 4.07$ (s, 3H), 4.04 (s, 3H). MS (ESI) $m / z:[\mathrm{M}+\mathrm{H}]^{+}$calcd for $\mathrm{C}_{16} \mathrm{H}_{14} \mathrm{BrN}_{4} \mathrm{O}_{3}{ }^{+} 389.02$, found 389.1, 391.1 .

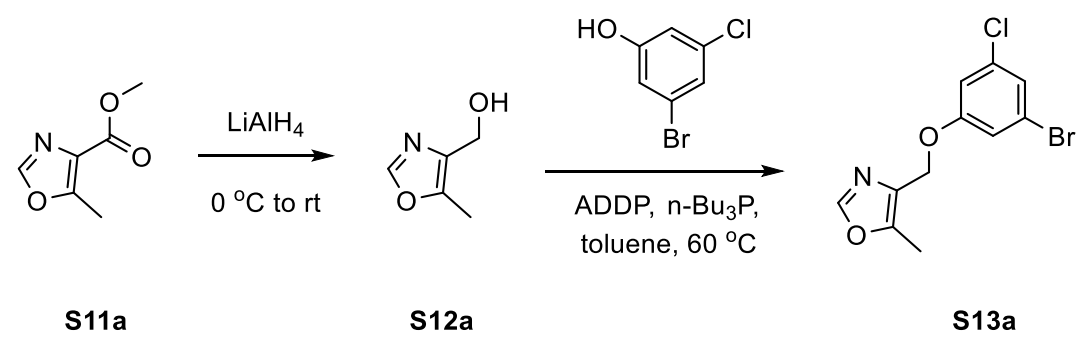

(5-Methyloxazol-4-yl)methanol (S12a). To a solution of methyl 5-methyloxazole-4-carboxylate (S11a, $1 \mathrm{~g}, 7.08 \mathrm{mmol}, 1.0 \mathrm{eq})$ in dry tetrahydrofuran $(10 \mathrm{~mL})$ was dropwise added lithium aluminum hydride $(7.1 \mathrm{~mL}, 7.1 \mathrm{mmol}, 1.0 \mathrm{eq})\left(1 \mathrm{M}\right.$ in THF) at $0{ }^{\circ} \mathrm{C}$ under $\mathrm{N}_{2}$. After the mixture was stirred at $0^{\circ} \mathrm{C}$ for $30 \mathrm{~min}$, it was warmed to room temperature and stirred for $30 \mathrm{~min}$. The reaction mixture was cooled to $0^{\circ} \mathrm{C}$ and quenched by water (until the $\mathrm{H}_{2}$ gas evolution ceased), followed by $1 \mathrm{~N} \mathrm{NaOH}$ solution $(2 \mathrm{~mL})$, brine $(20 \mathrm{~mL})$, filtered through celite, the precipitate was washed with ethyl acetate. The filtrate was extracted with ethyl acetate $(3 \times 40 \mathrm{~mL})$, and the organic layers were combined, dried over $\mathrm{Na}_{2} \mathrm{SO}_{4}$, filtered and concentrated in vacuum to give crude compound as an oil $(0.608 \mathrm{~g}, 76 \%$ yield). The crude material was used for next step without further purification. ${ }^{1} \mathrm{H}$ NMR $\left(400 \mathrm{MHz}, \mathrm{DMSO}-d_{6}\right) \delta 8.07(\mathrm{~s}, 1 \mathrm{H}), 4.93(\mathrm{t}, J=5.5 \mathrm{~Hz}, 1 \mathrm{H}), 4.27(\mathrm{~d}, J=$ $5.2 \mathrm{~Hz}, 2 \mathrm{H}), 2.26(\mathrm{~s}, 3 \mathrm{H})$. MS (ESI) $\mathrm{m} / z$ : [M-H] $]^{-}$calcd for $\mathrm{C}_{5} \mathrm{H}_{6} \mathrm{NO}_{2}{ }^{-} 112.04$, found 112.0.

\section{4-((3-Bromo-5-chlorophenoxy)methyl)-5-methyloxazole (S13a). (5-Methyloxazol-4-yl)} methanol (S12a, $0.608 \mathrm{~g}, 5.37 \mathrm{mmol}, 1.0 \mathrm{eq}$ ), 3-bromo-5-chlorophenol (1.11 g, $5.37 \mathrm{mmol}, 1.0 \mathrm{eq})$ and diphenylpiperidylcarboxylate $(3.39 \mathrm{~g}, 13.4 \mathrm{mmol}, 2.5 \mathrm{eq})$ were dissolved in dry toluene (60 $\mathrm{mL})$. The mixture underwent 3 cycles of vacuum/filling with $\mathrm{N}_{2}$, tributylphosphine $(2.71 \mathrm{~g}, 13.4$ mmol, 2.5 eq) was added and the solution was stirred at $60{ }^{\circ} \mathrm{C}$ overnight. Then the mixture was cooled to room temperature, filtered and washed with ethyl acetate $(30 \mathrm{~mL})$, the crude product was purified using silica gel chromatography with an ethyl acetate/hexanes gradient $(0-10 \%)$ to yield the desired product as a beige solid (766 mg, $47 \%$ yield). ${ }^{1} \mathbf{H}$ NMR $\left(400 \mathrm{MHz}, \mathrm{CDCl}_{3}\right) \delta 7.75(\mathrm{~s}$, $1 \mathrm{H}), 7.11(\mathrm{t}, J=1.5 \mathrm{~Hz}, 1 \mathrm{H}), 7.03(\mathrm{t}, J=1.9 \mathrm{~Hz}, 1 \mathrm{H}), 6.92(\mathrm{t}, J=1.9 \mathrm{~Hz}, 1 \mathrm{H}), 4.90(\mathrm{~s}, 2 \mathrm{H}), 2.36$ (s, 3H). MS (ESI) $m / z$ : [M+H] calcd for $\mathrm{C}_{11} \mathrm{H}_{10} \mathrm{BrClNO}_{2}{ }^{+}$301.96, found 302.0, 304.0.

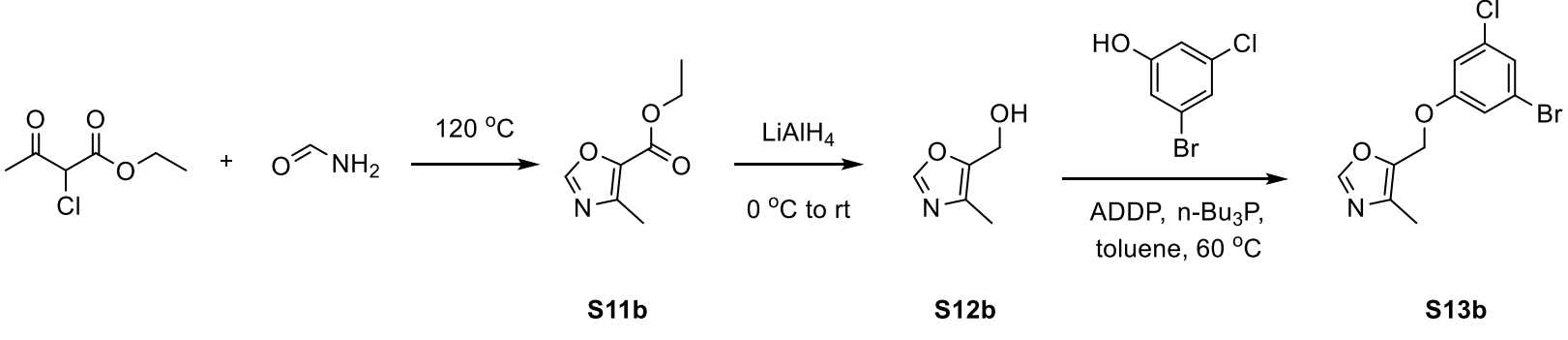

Ethyl 4-methyloxazole-5-carboxylate (S11b). Ethyl 2-chloro-3-oxobutanoate (2 g, $12.16 \mathrm{mmol})$ was added to formamide $(20 \mathrm{~mL})$ and stirred at $120^{\circ} \mathrm{C}$ for $15 \mathrm{~h}$, the mixture was extracted with 
dichloromethane $(2 \times 40 \mathrm{~mL})$ and water $(40 \mathrm{~mL})$. The combined organic layer was washed with brine $(40 \mathrm{~mL})$ and concentrated in vacuo, and the crude product was purified using silica gel chromatography with an ethyl acetate/hexanes gradient (0-5\%) to yield the desired compound as a clear oil (0.864 g, $45.8 \%$ yield). ${ }^{1} \mathbf{H}$ NMR (400 $\left.\mathrm{MHz} \mathrm{CDCl}_{3}\right) \delta 7.89$ (s, 1H), 4.40 (q, $J=7.1$ $\mathrm{Hz}, 2 \mathrm{H}), 2.50(\mathrm{~s}, 3 \mathrm{H}), 1.40(\mathrm{t}, J=7.1 \mathrm{~Hz}, 3 \mathrm{H})$. MS (ESI) $m / z$ : $[\mathrm{M}+\mathrm{H}]^{+}$calcd for $\mathrm{C}_{7} \mathrm{H}_{10} \mathrm{NO}_{3}{ }^{+} 156.07$, found 156.1 .

(4-Methyloxazol-5-yl)methanol (S12b). S12b was prepared according to the procedure described for the synthesis of S12a using ethyl 4-methyloxazole-5-carboxylate (S11b, $0.864 \mathrm{~g}$ ), pale yellow oil, 0.33 g, yield $52 \%$. ${ }^{1}$ H NMR (400 MHz, DMSO- $\left.d_{6}\right) \delta 8.13(\mathrm{~s}, 1 \mathrm{H}), 5.17(\mathrm{t}, J=5.7 \mathrm{~Hz}, 1 \mathrm{H})$, $4.38(\mathrm{~d}, J=5.7 \mathrm{~Hz}, 2 \mathrm{H}), 2.05(\mathrm{~s}, 3 \mathrm{H})$. MS (ESI) $m / z$ : [M-H] ${ }^{-}$calcd for $\mathrm{C}_{5} \mathrm{H}_{6} \mathrm{NO}_{2}{ }^{-} 112.04$, found 112.0.

5-((3-Bromo-5-chlorophenoxy)methyl)-4-methyloxazole (S13b). S13b was prepared according to the procedure described for the synthesis of S13a using (4-methyloxazol-5-yl)methanol (S12b, $0.33 \mathrm{~g}$ ) and 3-bromo-5-chlorophenol, $0.503 \mathrm{~g}$, yield $57 \%$. ${ }^{\mathbf{1}} \mathbf{H} \mathbf{N M R}\left(400 \mathrm{MHz}, \mathrm{CDCl}_{3}\right) \delta 7.84$ (s, $1 \mathrm{H}), 7.16(\mathrm{t}, J=1.5 \mathrm{~Hz}, 1 \mathrm{H}), 7.05-7.00(\mathrm{~m}, 1 \mathrm{H}), 6.91(\mathrm{t}, J=1.9 \mathrm{~Hz}, 1 \mathrm{H}), 4.99(\mathrm{~s}, 2 \mathrm{H}), 2.25(\mathrm{~s}$, $3 \mathrm{H})$. MS (ESI) $m / z:[\mathrm{M}+\mathrm{H}]^{+}$calcd for $\mathrm{C}_{11} \mathrm{H}_{10} \mathrm{BrClNO}_{2}{ }^{+}$301.96, found 302.0, 304.0.

\section{4-((3-Bromo-5-chlorophenoxy)methyl)-5-methylthiazole (S13c).}

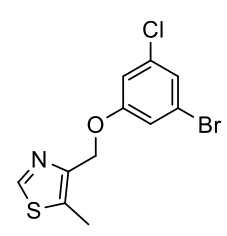

S13c was prepared according to the procedure described for the synthesis of S13a using (5-methylthiazol-4-yl)methanol and 3-bromo-5-chlorophenol, $309 \mathrm{mg}$, yield $63 \% .{ }^{1} \mathbf{H}$ NMR $\left(400 \mathrm{MHz}, \mathrm{CDCl}_{3}\right) \delta 8.62(\mathrm{~s}, 1 \mathrm{H}), 7.12(\mathrm{~d}, J=1.5 \mathrm{~Hz}, 1 \mathrm{H}), 7.10-$ $7.05(\mathrm{~m}, 1 \mathrm{H}), 6.97(\mathrm{t}, J=1.9 \mathrm{~Hz}, 1 \mathrm{H}), 5.13(\mathrm{~s}, 2 \mathrm{H}), 2.52(\mathrm{~s}, 3 \mathrm{H})$. MS (ESI) $m / z$ : $[\mathrm{M}+\mathrm{H}]^{+}$calcd for $\mathrm{C}_{11} \mathrm{H}_{10} \mathrm{BrClNOS}^{+}$317.93, found 318.0, 320.0.
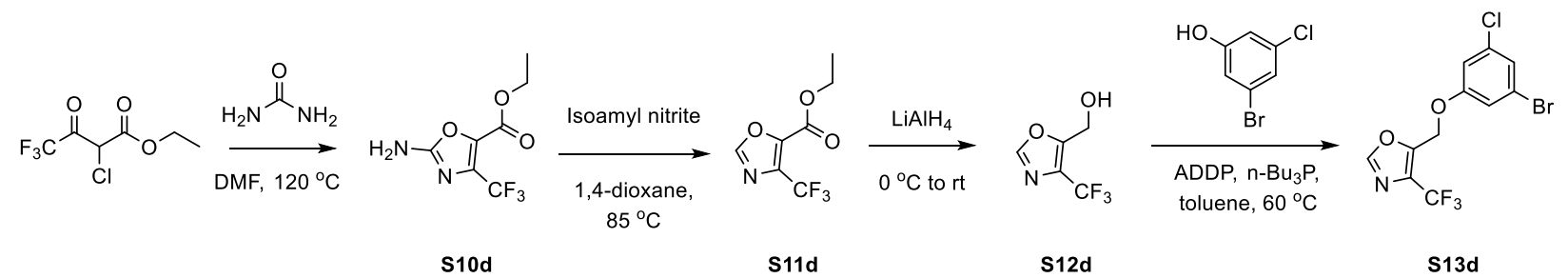

Ethyl 2-amino-4-(trifluoromethyl)oxazole-5-carboxylate (S10d). Ethyl 2-chloro-4,4,4trifluoro-3-oxobutanoate (10.93 g, $50 \mathrm{mmol}, 1.0 \mathrm{eq})$ and urea (7.5 g, $125 \mathrm{mmol}, 2.5 \mathrm{eq})$ were dissolved in DMF $(50 \mathrm{~mL})$, the mixture underwent 3 cycles of vacuum/filling with $\mathrm{N}_{2}$, and the solution was stirred at $120{ }^{\circ} \mathrm{C}$ overnight. After the mixture was cooled to room temperature, water $(100 \mathrm{~mL})$ was added, and the solid was filtered and washed with water $(50 \mathrm{~mL})$ and dried with lyophilizer to yield the target product as a pale yellow solid (6.92 g, $61.7 \%$ yield). ${ }^{1} \mathbf{H}$ NMR (400, DMSO-d $d_{6} \delta 7.98(\mathrm{~s}, 2 \mathrm{H}), 4.23(\mathrm{q}, J=7.1 \mathrm{~Hz}, 2 \mathrm{H}), 1.22(\mathrm{t}, J=7.1 \mathrm{~Hz}, 3 \mathrm{H}) .{ }^{19} \mathbf{F}$ NMR $(376 \mathrm{MHz}$, DMSO) $\delta$-61.41. MS (ESI) $m / z$ : $[\mathrm{M}+\mathrm{H}]^{+}$calcd for $\mathrm{C}_{7} \mathrm{H}_{8} \mathrm{~F}_{3} \mathrm{~N}_{2} \mathrm{O}_{3}{ }^{+} 225.05$, found 225.1.

Ethyl 4-(trifluoromethyl)oxazole-5-carboxylate (S11d). Ethyl 2-amino-4-(trifluoromethyl) oxazole-5-carboxylate (S10d, $6.92 \mathrm{~g}, 30.86 \mathrm{mmol}, 1.0 \mathrm{eq})$ was dissolved in dry 1,4-dioxane (65 
$\mathrm{mL}$ ), the mixture underwent 3 cycles of vacuum/filling with $\mathrm{N}_{2}$. Isoamyl nitrite $(7.23 \mathrm{~g}, 61.73$ mmol, 2.0 eq) was added and the mixture was stirred at $90{ }^{\circ} \mathrm{C}$ for 3 days. After the reaction was complete, the mixture was concentrated in vacuo and the residue was purified using silica gel chromatography with an ethyl acetate/hexanes gradient (0-5\%) to yield the desired product as a yellow oil (4.74 g, $73 \%$ yield) ${ }^{1} \mathbf{H}$ NMR (400 MHz, $\left.\mathrm{CDCl}_{3}\right) \delta 8.01(\mathrm{~s}, 1 \mathrm{H}), 4.43(\mathrm{q}, J=7.1 \mathrm{~Hz}$, $2 \mathrm{H}), 1.38(\mathrm{t}, J=7.1 \mathrm{~Hz}, 3 \mathrm{H}) .{ }^{19} \mathbf{F}$ NMR $\left(376 \mathrm{MHz}, \mathrm{CDCl}_{3}\right) \delta-61.80$. MS (ESI) $m / z:[\mathrm{M}+\mathrm{H}]^{+}$calcd for $\mathrm{C}_{7} \mathrm{H}_{7} \mathrm{~F}_{3} \mathrm{NO}_{3}{ }^{+}$210.04, found 210.0.

(4-(Trifluoromethyl)oxazol-5-yl)methanol (S12d). S12d was prepared according to the procedure described for the synthesis of S12a using ethyl 4-(trifluoromethyl)oxazole-5carboxylate (S11d, 4.74 g), brown oil, 1.59 g, yield $42 \%$. ${ }^{1} \mathbf{H}$ NMR (400 MHz, $\left.\mathrm{CDCl}_{3}\right) \delta 7.89$ (s, 1H), 4.80 (s, 2H), 2.50 (br.s, $1 \mathrm{H}) .{ }^{19}$ F NMR (376 MHz, $\left.\mathrm{CDCl}_{3}\right) \delta-62.39$. MS (ESI) $\mathrm{m} / z$ : $[\mathrm{M}-\mathrm{H}]^{-}$ calcd for $\mathrm{C}_{5} \mathrm{H}_{3} \mathrm{~F}_{3} \mathrm{NO}_{2}^{-}$166.01, found 166.0 .

5-((3-Bromo-5-chlorophenoxy)methyl)-4-(trifluoromethyl)oxazole (S13d). S13d was prepared according to the procedure described for the synthesis of S13a using (4-(trifluoromethyl)oxazol5-yl)methanol (S12d) and 3-bromo-5-chlorophenol. ${ }^{1} \mathbf{H}$ NMR (400 MHz, $\left.\mathrm{CDCl}_{3}\right) \delta 7.96(\mathrm{~s}, 1 \mathrm{H})$, $7.18(\mathrm{~s}, 1 \mathrm{H}), 7.01(\mathrm{~s}, 1 \mathrm{H}), 6.90(\mathrm{~s}, 1 \mathrm{H}), 5.14(\mathrm{~s}, 2 \mathrm{H}) .{ }^{19} \mathbf{F}$ NMR $\left(376 \mathrm{MHz}, \mathrm{CDCl}_{3}\right) \delta-62.57 . \mathbf{M S}$ (ESI) $m / z:[\mathrm{M}+\mathrm{H}]^{+}$calcd for $\mathrm{C}_{11} \mathrm{H}_{7} \mathrm{BrClF}_{3} \mathrm{NO}_{2}{ }^{+}$355.93, found 355.9, 357.9 .

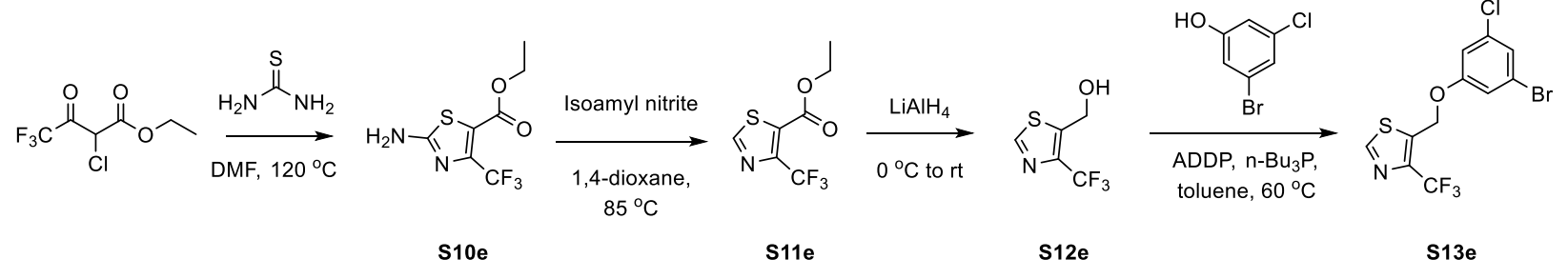

\section{Ethyl 2-amino-4-(trifluoromethyl)thiazole-5-carboxylate (S10e).}

Ethyl 2-chloro-4,4,4-trifluoro-3-oxobutanoate ( $8.74 \mathrm{~g}, 40 \mathrm{mmol}, 1.0 \mathrm{eq})$ and thiourea (7.6 g, 100 mmol, $2.5 \mathrm{eq})$ were dissolved in DMF $(50 \mathrm{~mL})$, the mixture underwent 3 cycles of vacuum/filling with $\mathrm{N}_{2}$, and the solution was stirred at $120^{\circ} \mathrm{C}$ overnight. After the mixture was cooled to room temperature, water $(100 \mathrm{~mL})$ was added, the solid was filtered and washed with water $(50 \mathrm{~mL})$ and dried with lyophilizer to yield the target product as a white solid (5.4 g, $56.2 \%$ yield). ${ }^{\mathbf{1}} \mathbf{H}$ NMR $(400$, DMSO-d $) \delta 8.20(\mathrm{~s}, 2 \mathrm{H}), 4.18(\mathrm{q}, J=7.1 \mathrm{~Hz}, 2 \mathrm{H}), 1.20(\mathrm{t}, J=7.1 \mathrm{~Hz}, 3 \mathrm{H}) .{ }^{19} \mathbf{F}$ NMR $(376$ MHz, DMSO) $\delta$-60.31. MS (ESI) $m / z$ : $[\mathrm{M}+\mathrm{H}]^{+}$calcd for $\mathrm{C}_{7} \mathrm{H}_{8} \mathrm{~F}_{3} \mathrm{~N}_{2} \mathrm{O}_{2} \mathrm{~S}^{+}$241.03, found 241.2.

\section{Ethyl 4-(trifluoromethyl)thiazole-5-carboxylate (S11e).}

Ethyl 2-amino-4-(trifluoromethyl) thiazole-5-carboxylate (S10e, $5.4 \mathrm{~g}, 22.48 \mathrm{mmol}, 1.0 \mathrm{eq}$ ) was dissolved in dry 1,4-dioxane $(60 \mathrm{~mL})$, the mixture underwent 3 cycles of vacuum/filling with $\mathrm{N}_{2}$. Isoamyl nitrite ( $5.3 \mathrm{~g}, 45 \mathrm{mmol}, 2.0 \mathrm{eq}$ ) was added and the mixture was stirred at $90{ }^{\circ} \mathrm{C}$ for 5 hours. After the reaction was complete, the mixture was concentrated in vacuo and the residue was purified using silica gel chromatography with an ethyl acetate/hexanes gradient $(0-5 \%)$ to yield the desired product as a yellow oil (3.89 g, $76.5 \%$ yield) ${ }^{1} \mathbf{H}$ NMR (400 MHz, $\left.\mathrm{CDCl}_{3}\right) \delta 8.87(\mathrm{~s}$, 
$1 \mathrm{H}), 4.40(\mathrm{q}, J=7.1 \mathrm{~Hz}, 2 \mathrm{H}), 1.38(\mathrm{t}, J=7.1 \mathrm{~Hz}, 3 \mathrm{H}) .{ }^{19} \mathbf{F ~ N M R}\left(376 \mathrm{MHz}, \mathrm{CDCl}_{3}\right) \delta-60.81 . \mathbf{M S}$ (ESI) $m / z:[\mathrm{M}+\mathrm{H}]^{+}$calcd for $\mathrm{C}_{7} \mathrm{H}_{7} \mathrm{~F}_{3} \mathrm{NO}_{2} \mathrm{~S}^{+} 226.01$, found 226.0 .

\section{(4-(Trifluoromethyl)thiazol-5-yl)methanol (S12e).}

S12e was prepared according to the procedure described for the synthesis of S12a using ethyl 4(trifluoromethyl)thiazole-5-carboxylate (S11e, $3.89 \mathrm{~g}$ ), brown oil, $1.48 \mathrm{~g}$, yield $47 \%$. ${ }^{\mathbf{1}} \mathbf{H}$ NMR $\left(400 \mathrm{MHz}, \mathrm{CDCl}_{3}\right) \delta 8.71(\mathrm{~s}, 1 \mathrm{H}), 5.02(\mathrm{~d}, J=3.8 \mathrm{~Hz}, 2 \mathrm{H}), 3.43(\mathrm{t}, J=5.2 \mathrm{~Hz}, 1 \mathrm{H}) .{ }^{19} \mathbf{F}$ NMR $\left(376 \mathrm{MHz}, \mathrm{CDCl}_{3}\right) \delta-60.83$. MS (ESI) $m / z$ : [M-H] $]^{-}$calcd for $\mathrm{C}_{5} \mathrm{H}_{3} \mathrm{~F}_{3} \mathrm{NOS}^{-} 181.99$, found 182.0.

\section{5-((3-Bromo-5-chlorophenoxy)methyl)-4-(trifluoromethyl)thiazole (S13e).}

S13e was prepared according to the procedure described for the synthesis of S13a using (4(trifluoromethyl)thiazol-5-yl)methanol (S12e) and 3-bromo-5-chlorophenol. ${ }^{1} \mathbf{H}$ NMR (400 MHz, $\left.\mathrm{CDCl}_{3}\right) \delta 8.82(\mathrm{~s}, 1 \mathrm{H}), 7.19(\mathrm{~s}, 1 \mathrm{H}), 7.02(\mathrm{~s}, 1 \mathrm{H}), 6.91(\mathrm{~s}, 1 \mathrm{H}), 5.36(\mathrm{~s}, 2 \mathrm{H}) .{ }^{19} \mathbf{F ~ N M R}(376 \mathrm{MHz}$, $\left.\mathrm{CDCl}_{3}\right) \delta$-60.78. MS (ESI) $m / z$ : [M+H] ${ }^{+}$calcd for $\mathrm{C}_{11} \mathrm{H}_{7} \mathrm{BrClF}_{3} \mathrm{NOS}^{+}$371.91, found 371.9, 373.9 .

\section{1-Bromo-3-chloro-5-(3,3,3-trifluoropropoxy)benzene (S13f)}

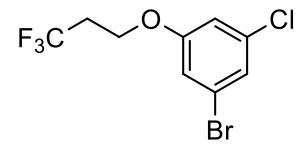

S13f was prepared according to the procedure described for the synthesis of S13a using 3,3,3-trifluoropropan-1-ol and 3-bromo-5-chlorophenol. ${ }^{1} \mathbf{H}$ NMR $\left(400 \mathrm{MHz}, \mathrm{CDCl}_{3}\right) \delta 7.14(\mathrm{t}, J=1.6 \mathrm{~Hz}, 1 \mathrm{H}), 6.97-6.93(\mathrm{~m}, 1 \mathrm{H}), 6.84(\mathrm{t}, J=$ $2.0 \mathrm{~Hz}, 1 \mathrm{H}), 4.16$ (t, $J=6.5 \mathrm{~Hz}, 2 \mathrm{H}), 2.62$ (qt, $J=10.4,6.5 \mathrm{~Hz}, 2 \mathrm{H})$.

\section{1-Bromo-3-chloro-5-(cyclopropylmethoxy)benzene (S13g)}

To a solution of 3-bromo-5-chlorophenol (1.04 g, $5.0 \mathrm{mmol}, 1.0 \mathrm{eq})$ and $\mathrm{K}_{2} \mathrm{CO}_{3}$<smiles>Clc1cc(Br)cc(OCC2CC2)c1</smiles>

(1.38 g, $10 \mathrm{mmol}, 2.0 \mathrm{eq})$ in DMF $(30 \mathrm{~mL}$ ), (chloromethyl)cyclopropane (462 $\mathrm{mg}, 5.1 \mathrm{mmol}, 1.02 \mathrm{eq}$ ) was added and the solution was stirred at $80^{\circ} \mathrm{C}$ for $1 \mathrm{~h}$.

Once complete, the mixture was concentrated in vacuo and the residue was resuspended in water $(40 \mathrm{~mL})$ and extracted with dichloromethane $(2 \times 40 \mathrm{~mL})$. The combined organic layer was concentrated in vacuo and the crude product was purified using silica gel chromatography (100\% hexane) to yield the desired compound. ${ }^{1} \mathbf{H}$ NMR $\left(400 \mathrm{MHz}, \mathrm{CDCl}_{3}\right) \delta$ $7.06(\mathrm{~s}, 1 \mathrm{H}), 6.92(\mathrm{~s}, 1 \mathrm{H}), 6.81(\mathrm{~s}, 1 \mathrm{H}), 3.75(\mathrm{~d}, \mathrm{~J}=6.9 \mathrm{~Hz}, 2 \mathrm{H}), 1.28-1.18(\mathrm{~m}, 1 \mathrm{H}), 0.64(\mathrm{q}, \mathrm{J}=$ $5.2,4.5 \mathrm{~Hz}, 2 \mathrm{H}), 0.32(\mathrm{~d}, \mathrm{~J}=4.8 \mathrm{~Hz}, 2 \mathrm{H})$.

\section{1-Bromo-3-chloro-5-(cyclopentylmethoxy)benzene (S13h)}

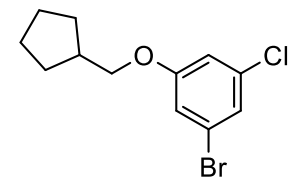

To a solution of 3-bromo-5-chlorophenol (1.04 g, $5.0 \mathrm{mmol}, 1.0 \mathrm{eq})$ and $\mathrm{K}_{2} \mathrm{CO}_{3}$ (1.38 g, $10 \mathrm{mmol}, 2.0 \mathrm{eq})$ in DMF (30 mL), (bromomethyl)cyclopentane $(0.897$ $\mathrm{g}, 5.1 \mathrm{mmol}, 1.02 \mathrm{eq})$ was added and the solution was stirred at $80^{\circ} \mathrm{C}$ for $3 \mathrm{hrs}$. Once complete, the mixture was concentrated in vacuo and the residue was resuspended in water $(40 \mathrm{~mL})$ and extracted with dichloromethane $(2 \times 40 \mathrm{~mL})$. The combined organic layer was dried over $\mathrm{Na}_{2} \mathrm{SO}_{4}$, filtered, and concentrated in vacuo. The crude product was purified using normal phase column chromatography (SNAP Ultra 100g, gradient $=0 \%$ EtOAc/Hex over $3 \mathrm{CV}$, then 0-20\% EtOAc/Hex over $2 \mathrm{CV}$, then $20 \% \mathrm{EtOAc} / \mathrm{Hex}$ over $3 \mathrm{CV}$ ) to afford $0.764 \mathrm{mg}$ (53\% yield) of a pale-yellow oil. ${ }^{1} \mathbf{H}$ NMR $\left(400 \mathrm{MHz}, \mathrm{CDCl}_{3}\right) \delta 7.07(\mathrm{t}, J=1.7$ 
$\mathrm{Hz}, 1 \mathrm{H}), 6.95(\mathrm{t}, J=2.0 \mathrm{~Hz}, 1 \mathrm{H}), 6.83$ (t, $J=2.1 \mathrm{~Hz}, 1 \mathrm{H}), 3.79$ (d, $J=6.9 \mathrm{~Hz}, 2 \mathrm{H}), 2.33$ (hept, $J=$ $7.4 \mathrm{~Hz}, 1 \mathrm{H}), 1.82(\mathrm{dq}, J=12.4,6.2,5.8 \mathrm{~Hz}, 2 \mathrm{H}), 1.70-1.55(\mathrm{~m}, 4 \mathrm{H}), 1.40-1.24$ (m, $2 \mathrm{H})$.

\section{3-((3-bromo-5-chlorophenoxy)methyl)-2-chlorothiophene (S13i).}

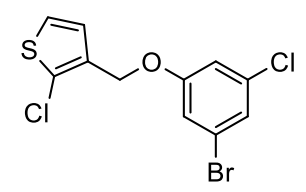

S13i was prepared according to the procedure described for the synthesis of S13g using 2-chloro-3-(chloromethyl)thiophene and 3-bromo-5-chlorophenol as a clear oil. ${ }^{1} \mathbf{H}$ NMR $\left(400 \mathrm{MHz}, \mathrm{CDCl}_{3}\right) \delta 7.12(\mathrm{~d}, J=5.6 \mathrm{~Hz}, 2 \mathrm{H}), 7.03-$ $6.98(\mathrm{~m}, 2 \mathrm{H}), 6.89(\mathrm{t}, J=1.9 \mathrm{~Hz}, 1 \mathrm{H}), 4.96(\mathrm{~s}, 2 \mathrm{H})$.

\section{5-Bromo-1-chloro-3-((2-chlorobenzyl)oxy)-2-fluorobenzene (S13j).}

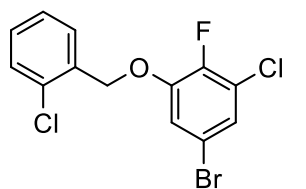

Compound $\mathbf{S 1 3} \mathbf{j}$ was prepared according to to the procedure described for the synthesis of S13g using 5-bromo-3-chloro-2-fluorophenol and 1-chloro-2(chloromethyl)benzene. ${ }^{1} \mathbf{H}$ NMR $\left(400 \mathrm{MHz} \mathrm{CDCl}_{3}\right) \delta 7.55$ (dd, $J=6.8,2.5$ $\mathrm{Hz}, 1 \mathrm{H}), 7.44-7.39$ (m, 1H), $7.33-7.29$ (m, 2H), 7.17 (dd, $J=5.6,2.2 \mathrm{~Hz}$, 1H), 7.07 (dd, $J=6.7,2.2 \mathrm{~Hz}, 1 \mathrm{H}), 5.20(\mathrm{~s}, 2 \mathrm{H})$.

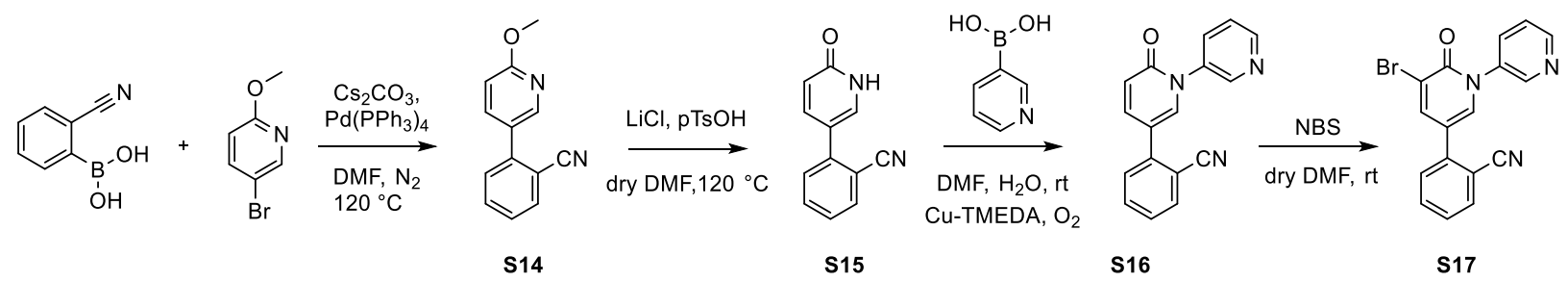

2-(6-Methoxypyridin-3-yl)benzonitrile (S14)

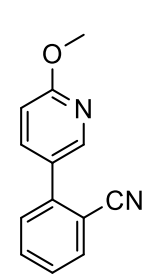

To a 250-mL thick walled round bottom flask 2-cyanophenyl boronic acid (2.204 g, 1.5 mmol, 15.0 equiv), 5-bromo-2-methoxypyridine (1.30 mL, $10.0 \mathrm{mmol}, 1.0$ equiv), palladium tetrakis $(1.156 \mathrm{~g}, 10 \mathrm{~mol} \%), \mathrm{Cs}_{2} \mathrm{CO}_{3}(6.516 \mathrm{~g}, 20.0 \mathrm{mmol}, 2.0$ equiv) and DMF $(100 \mathrm{~mL})$ were added. The solution was sparged with $\mathrm{N}_{2}$ then the flask was sealed with a screw cap. The reaction was allowed to stir at $120^{\circ} \mathrm{C}$ for 15 hours. Once cooled to room temperature, the solvent was removed. The crude material was resuspended in EtOAc and extracted from water with EtOAc (3X) and DCM (3X). The combined organic layers were then dried over $\mathrm{Na}_{2} \mathrm{SO}_{4}$, filtered, and concentrated in vacuo. The crude material was then subjected to normal phase column chromatography (SNAP Ultra 100g, gradient $=0-10 \%$ EtOAc/Hex over 4 $\mathrm{CV}$, then 10-15\% EtOAc/Hex over $4 \mathrm{CV}$, then 15-100\% EtOAc/Hex over $2 \mathrm{CV}$ ) to afford a white solid (1.497 g, $7.1 \mathrm{mmol}, 71 \%$ yield). ${ }^{1} \mathbf{H}$ NMR (600 MHz, $\left.\mathrm{CDCl}_{3}\right) \delta 8.33$ (d, $\left.J=2.4 \mathrm{~Hz}, 1 \mathrm{H}\right)$, $7.82(\mathrm{dd}, J=8.6,2.6 \mathrm{~Hz}, 1 \mathrm{H}), 7.79-7.75(\mathrm{~m}, 1 \mathrm{H}), 7.66(\mathrm{td}, J=7.7,1.4 \mathrm{~Hz}, 1 \mathrm{H}), 7.49-7.48(\mathrm{~m}$, $1 \mathrm{H}), 7.46(\mathrm{td}, J=7.7,1.2 \mathrm{~Hz}, 1 \mathrm{H}), 6.87(\mathrm{dd}, J=8.6,0.8 \mathrm{~Hz}, 1 \mathrm{H}), 4.00(\mathrm{~s}, 3 \mathrm{H}) .{ }^{13} \mathbf{C}$ NMR (151 $\left.\mathrm{MHz}, \mathrm{CDCl}_{3}\right) \delta 164.5,146.8,142.2,138.9,134.0,133.2,129.9,127.9,127.3,118.6,111.5,111.0$, 53.9. HRMS (ESI) $m / z$ : $[\mathrm{M}+\mathrm{H}]^{+}$calcd for $\mathrm{C}_{13} \mathrm{H}_{11} \mathrm{~N}_{2} \mathrm{O}^{+} 211.0866$, found 211.0880 .

\section{2-(6-Oxo-1,6-dihydropyridin-3-yl)benzonitrile (S15)}




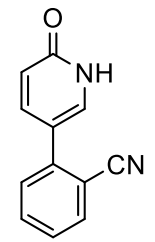

A 40-mL thick walled flask equipped with a stir bar was charged with $\mathbf{S 1 4}(1.000 \mathrm{~g}, 4.76$ mmol, 1.0 equiv), lithium chloride ( $1.008 \mathrm{~g}, 23.80 \mathrm{mmol}, 5.0$ equiv), $p$-toluenesulfonic acid (4.095 g, $23.80 \mathrm{mmol}, 5.0$ equiv), and DMF (16 mL). The flask was sealed with a screw cap and then heated to $120^{\circ} \mathrm{C}$ for 2 hours. Once cooled to room temperature, the solution was quenched with water and subsequently filtered to afford a white solid (0.934 g, quant. yield). ${ }^{1} \mathbf{H}$ NMR (600 MHz, DMSO- $\left.d_{6}\right) \delta 11.98(\mathrm{~s}, 1 \mathrm{H}), 7.96-7.87(\mathrm{~m}, 1 \mathrm{H}), 7.74$ $(\mathrm{td}, J=7.8,1.2 \mathrm{~Hz}, 1 \mathrm{H}), 7.71-7.66(\mathrm{~m}, 2 \mathrm{H}), 7.60(\mathrm{~d}, J=7.9 \mathrm{~Hz}, 1 \mathrm{H}), 7.52(\mathrm{t}, J=7.6 \mathrm{~Hz}, 1 \mathrm{H})$, $6.51-6.42(\mathrm{~m}, 1 \mathrm{H}) .{ }^{13} \mathrm{C}$ NMR $\left(151 \mathrm{MHz}, \mathrm{DMSO}-d_{6}\right) \delta 161.6,141.3,140.4,135.7,133.8,133.6$, 129.4, 127.8, 119.7, 118.5, 115.4, 109.7. HRMS (ESI) $m / z$ : $[\mathrm{M}+\mathrm{H}]^{+}$calcd for $\mathrm{C}_{12} \mathrm{H}_{9} \mathrm{~N}_{2} \mathrm{O}^{+}$ 197.0709, found 197.0714.

\section{2-(2-Oxo-2H-[1,3'-bipyridin]-5-yl)benzonitrile (S16)}

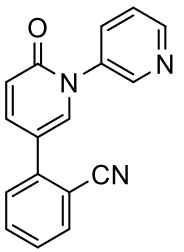

To a 2-dram vial equipped with a stir bar $\mathbf{S 1 5}$ (0.196 g, $1.00 \mathrm{mmol}, 1.0$ equiv), 3pyridinylboronic acid (0.246 g, $2.00 \mathrm{mmol}, 2.0$ equiv), Cu-TMEDA (0.0464 g, 10 mol\%), DMF $(4.0 \mathrm{~mL})$, and water $(0.2 \mathrm{~mL})$ were added. The reaction vessel was closed using a screw-cap with bonded septum, then affixed with an oxygen balloon and stirred under an oxygen atmosphere for 4 days. The mixture was then diluted with DCM and water. The aqueous layer was rinsed with DCM (5X). The combined organic layer was then dried with $\mathrm{Na}_{2} \mathrm{SO}_{4}$, filtered, and concentrated in vacuo. The crude material was purified using normal phase column chromatography (SNAP Ultra $50 \mathrm{~g}$, gradient $=0-6 \% \mathrm{DCM} / \mathrm{MeOH}$ over 5 $\mathrm{CV}$, then $6-7 \% \mathrm{DCM} / \mathrm{MeOH}$ over $3 \mathrm{CV}$, then $7-10 \% \mathrm{DCM} / \mathrm{MeOH}$ over $2 \mathrm{CV}$ ) to afford $0.184 \mathrm{~g}$ (67\% yield) of a white solid. ${ }^{1} \mathbf{H}$ NMR $\left(500 \mathrm{MHz}\right.$, DMSO- $\left.d_{6}\right) \delta 8.74(\mathrm{~d}, J=2.5 \mathrm{~Hz}, 1 \mathrm{H}), 8.66$ (dd, $J=4.8,1.4 \mathrm{~Hz}, 1 \mathrm{H}), 8.13(\mathrm{~d}, J=2.6 \mathrm{~Hz}, 1 \mathrm{H}), 8.01(\mathrm{ddd}, J=8.2,2.6,1.5 \mathrm{~Hz}, 1 \mathrm{H}), 7.94(\mathrm{dd}, J=$ 7.8, $1.2 \mathrm{~Hz}, 1 \mathrm{H}), 7.86(\mathrm{dd}, J=9.5,2.7 \mathrm{~Hz}, 1 \mathrm{H}), 7.77$ (td, $J=7.7,1.4 \mathrm{~Hz}, 1 \mathrm{H}), 7.72$ (dd, $J=8.0$, $1.2 \mathrm{~Hz}, 1 \mathrm{H}), 7.60(\mathrm{dd}, J=8.2,4.8 \mathrm{~Hz}, 1 \mathrm{H}), 7.56(\mathrm{td}, J=7.6,1.3 \mathrm{~Hz}, 1 \mathrm{H}), 6.69(\mathrm{~d}, J=9.5 \mathrm{~Hz}, 1 \mathrm{H})$. ${ }^{13}$ C NMR $\left(126 \mathrm{MHz}\right.$, DMSO- $\left.d_{6}\right) \delta 160.3,149.2,147.4,141.5,139.8,138.7,136.9,134.7,133.8$, 133.6, 129.6, 128.2, 123.8, 120.2, 118.6, 116.3, 110.0. HRMS (ESI) $\mathrm{m} / z:[\mathrm{M}+\mathrm{H}]^{+}$calcd for $\mathrm{C}_{17} \mathrm{H}_{12} \mathrm{~N}_{3} \mathrm{O}^{+} 274.0975$, found 274.0995 .

\section{2-(3-Bromo-2-oxo-2H-[1,3'-bipyridin]-5-yl)benzonitrile (S17)}

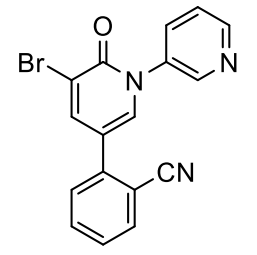

A 2-dram vial equipped with a stir bar was charged with crude $\mathbf{S 1 6}$ (0.273 g, 1.00 mmol, 1.0 equiv) and DMF (2 mL). While stirring at room temperature NBS $(0.214 \mathrm{~g}, 1.20 \mathrm{mmol}, 1.2$ equiv) was added. After 15 hours, the reaction was quenched with ice water, and subsequently filtered to afford $0.313 \mathrm{~g}$ of a white solid ( $89 \%$ yield), which was used without further purification. Analytically pure

material was obtained using normal phase column chromatography (SNAP Ultra 50g, gradient $=$ $0-100 \%$ EtOAc/Hex over $4 \mathrm{CV}$, then $100 \% \mathrm{EtOAc} / \mathrm{Hex}$ over $6 \mathrm{CV}) .{ }^{1} \mathbf{H} \mathbf{~ N M R}\left(500 \mathrm{MHz}, \mathrm{CDCl}_{3}\right)$ $\delta 8.77(\mathrm{~d}, J=2.5 \mathrm{~Hz}, 1 \mathrm{H}), 8.70$ (dd, $J=4.8,1.5 \mathrm{~Hz}, 1 \mathrm{H}), 8.05(\mathrm{~d}, J=2.5 \mathrm{~Hz}, 1 \mathrm{H}), 7.90$ (ddd, $J=$ 8.2, 2.6, $1.5 \mathrm{~Hz}, 1 \mathrm{H}), 7.77(\mathrm{dt}, J=7.4,1.1 \mathrm{~Hz}, 1 \mathrm{H}), 7.72-7.65(\mathrm{~m}, 2 \mathrm{H}), 7.50(\mathrm{~d}, J=7.8 \mathrm{~Hz}, 2 \mathrm{H})$, $7.49-7.46(\mathrm{~m}, 1 \mathrm{H}) .{ }^{13} \mathbf{C}$ NMR $\left(126 \mathrm{MHz}, \mathrm{CDCl}_{3}\right) \delta 157.7,150.3,147.3,142.7,138.9,137.26$, 
136.6, 134.3, 134.1, 133.6, 129.4, 128.8, 124.0, 118.3, 118.2, 117.5, 111.1. HRMS (ESI) $\mathrm{m} / \mathrm{z}$ : $[\mathrm{M}+\mathrm{H}]^{+}$calcd for $\mathrm{C}_{17} \mathrm{H}_{11} \mathrm{BrN}_{3} \mathrm{O}^{+} 352.0080$, found 352.0100.

\section{General Procedure A for Suzuki-Miyaura Cross-Coupling}

Aryl bromide (S17, 1.0 equiv), boronic acid (2.0 equiv), palladium tetrakis (10 mol\%), cesium carbonate (2.5 equiv) and DMF $(0.07 \mathrm{M})$ were added to a 2-dram vial equipped with a stir bar. The solution was sparged with $\mathrm{N}_{2}$, then the vial was sealed with a Teflon cap and heated to $120^{\circ} \mathrm{C}$ for $15-20$ hours. Once cooled to room temperature, the DMF was removed, and the crude material was purified via column chromatography to afford the desired product.

\section{General Procedure B for Suzuki-Miyaura Cross-Coupling}

Aryl bromide (S6,1.0 equiv), boronic acid (1.5 equiv), $\mathrm{PdCl}_{2}\left(\mathrm{PPh}_{3}\right)_{2}(10 \mathrm{~mol} \%)$, potassium carbonate (2.0 equiv) were suspended in DMF $(10 \mathrm{~mL})$. The mixture underwent three cycles of vacuum/filling with $\mathrm{N}_{2}$, then stirred at $120^{\circ} \mathrm{C}$ for $1 \mathrm{~h}$. After the reaction was complete, the mixture was concentrated in vacuo, then the residue was extracted with DCM $(2 \times 40 \mathrm{~mL})$ and water $(40$ $\mathrm{mL}$ ). The combined organic layer was concentrated, and the crude product was purified using silica gel chromatography with a dichloromethane / ethyl acetate / methanol $(92 \%$ / 5\% / 3\%) gradient to afford the desired product as a white solid.

\section{General Procedure C for Suzuki-Miyaura Cross-Coupling}

Aryl bromide (S13, 1.1 equiv), bis(pinacolato)diboron (1.15 equiv), KOAc (2.2 equiv), and $\left(\mathrm{PPh}_{3}\right)_{2} \mathrm{PdCl}_{2}(20 \mathrm{~mol} \%)$ and DMF $(0.04 \mathrm{M})$ were added to a 2-dram vial equipped with a stir bar. The solution was sparged with $\mathrm{N}_{2}$, then the vial was sealed with a Teflon cap and heated to $80^{\circ} \mathrm{C}$ for 1-3 hours. Once cooled to room temperature, methanol $(0.4 \mathrm{~mL})$ was added to scavenge excess of pinacolborane. Pyridone bromide ( $\mathbf{S 6}$ or $\mathbf{S 1 7}, 1.0$ equiv) and $\mathrm{K}_{2} \mathrm{CO}_{3}$ (2.0 equiv) were added to the solution, which was then sparged with $\mathrm{N}_{2}$, sealed with a Teflon cap, and heated to $120^{\circ} \mathrm{C}$ for 1-15 hours. Once cooled to room temperature, the DMF was removed, water was added, and the solution was extracted with DCM (3X). The combined organic layer was dried with $\mathrm{Na}_{2} \mathrm{SO}_{4}$, filtered, and then concentrated in vасио. Uracil compounds were purified using purified using silica gel chromatography with a dichloromethane / ethyl acetate / methanol (92\% / 5\% / 3\%) gradient to afford the target compound as a white solid. The purification of the cyanophenyl compounds is specified for each compound below. 


\section{General Procedure D for Final Uracil Demethylation}

Substituted 2,4-dimethyoxypyrimidine (S7, 1.0 equiv) was dissolved in dry DMF (10 mL) along with $\mathrm{LiCl}$ (10 equiv) and $p$-toluenesulfonic acid (10 equiv). The solution was then stirred at $80{ }^{\circ} \mathrm{C}$ for $30 \mathrm{~min}$. After completion, the mixture was concentrated in vacuo. The residue was suspended in saturated aqueous $\mathrm{NaHCO}_{3}(15 \mathrm{~mL})$, then the mixture was filtered. The solid was washed with saturated aqueous $\mathrm{NaHCO}_{3}$, water, and then hexanes. The material was then dried with a lyophilizer to yield the desired compound as a pale yellow solid.

\section{General Procedure E for 1-Methyl Uracil Compounds}

Substituted 2,4-dimethyoxypyrimidine (S7, 1.0 equiv) was dissolved in acetonitrile (10 $\mathrm{mL}$ ), iodomethane (10 equiv) was added, the solution was then stirred at $60{ }^{\circ} \mathrm{C}$ for $3 \mathrm{~h}$. After completion, the mixture was concentrated in vacuo. The crude product (S8) was used for next step without further purification.

The crude product (S8, 1.0 equiv) from previous step was dissolved in dry DMF along with $\mathrm{LiCl}$ (10 equiv) and $p$-toluenesulfonic acid (10 equiv). The solution was then stirred at $80{ }^{\circ} \mathrm{C}$ for $30 \mathrm{~min}$. After completion, the mixture was concentrated in vacuo. The residue was suspended in saturated aqueous $\mathrm{NaHCO}_{3}(15 \mathrm{~mL})$, then the mixture was filtered. The solid was washed with saturated aqueous $\mathrm{NaHCO}_{3}$ and water. The material was then dried with a lyophilizer to yield the crude product (S9) as a brown solid.

A 100-mL flask equipped with a stir bar was charged with the crude product $\mathbf{S 9}$ (1.0 equiv), tetrabutylammonium bromide ( 3 equiv) and dry diglyme $(20 \mathrm{~mL})$. The mixture underwent three cycles of vacuum/filling with $\mathrm{N}_{2}$, then stirred at $130{ }^{\circ} \mathrm{C}$ for $6 \mathrm{~h}$. After completion, the mixture was concentrated in vacuo and the residue was resuspended in water $(40 \mathrm{~mL})$ and extracted with dichloromethane $(3 \times 40 \mathrm{~mL})$. The combined organic layer was concentrated in vacuo and the crude

product was purified using silica gel chromatography (saturated with triethylamine) with a methanol/ dichloromethane gradient $(0-6 \%)$ to afford the target compounds.

\section{3-(3-Chloro-5-propoxyphenyl)-5-(2,4-dimethoxypyrimidin-5-yl)-2H-[1,3'-bipyridin]-2-one} (S7a)

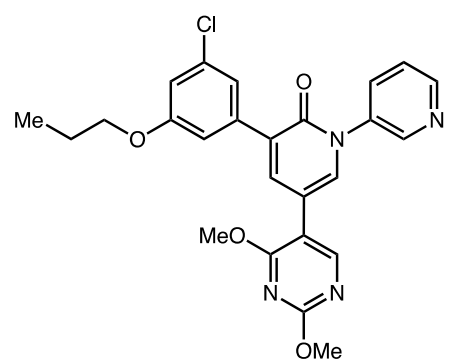

General Procedure B was employed using S6 and (3-chloro-5propoxyphenyl)boronic acid to afford the title compound as a white solid (130.6 mg, 68\% yield). ${ }^{1} \mathbf{H}$ NMR (400 MHz, $\left.\mathrm{CDCl}_{3}\right) \delta 8.75(\mathrm{~d}$, $J=15.5 \mathrm{~Hz}, 2 \mathrm{H}), 8.28(\mathrm{~s}, 1 \mathrm{H}), 7.99$ (d, $J=8.2 \mathrm{~Hz}, 1 \mathrm{H}), 7.76(\mathrm{~d}, J=$ $2.3 \mathrm{~Hz}, 1 \mathrm{H}), 7.62-7.50(\mathrm{~m}, 2 \mathrm{H}), 7.27(\mathrm{~s}, 1 \mathrm{H}), 7.26-7.19(\mathrm{~m}, 1 \mathrm{H})$, $6.92(\mathrm{t}, J=1.9 \mathrm{~Hz}, 1 \mathrm{H}), 4.07(\mathrm{~s}, 3 \mathrm{H}), 4.05(\mathrm{~s}, 3 \mathrm{H}), 3.94(\mathrm{t}, J=6.5 \mathrm{~Hz}$, $2 \mathrm{H}), 1.81-1.75(\mathrm{~m}, 2 \mathrm{H}), 1.02(\mathrm{t}, J=7.4 \mathrm{~Hz}, 3 \mathrm{H}) . \mathbf{M S}(\mathrm{ESI}) \mathrm{m} / \mathrm{z}$ : $[\mathrm{M}+\mathrm{H}]^{+}$calcd for $\mathrm{C}_{25} \mathrm{H}_{24} \mathrm{ClN}_{4} \mathrm{O}_{4}{ }^{+} 479.15$, found 479.2. 
3-(3-Chloro-5-(cyclopropylmethoxy)phenyl)-5-(2,4-dimethoxypyrimidin-5-yl)-2H-[1,3'bipyridin]-2-one (S7b)

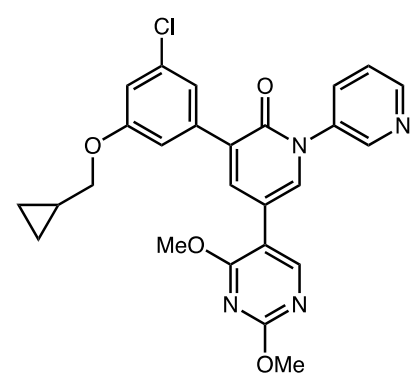

General Procedure C was employed using $\mathbf{S 6}$ and 1-bromo-3-chloro-5-

(cyclopropylmethoxy)benzene (S13g) to afford the title compound as a white solid (73.5 mg, 75\% yield). ${ }^{1} \mathbf{H}$ NMR $\left(400 \mathrm{MHz}, \mathrm{CDCl}_{3}\right) \delta 8.82$ (s, $1 \mathrm{H}), 8.74(\mathrm{~s}, 1 \mathrm{H}), 8.30(\mathrm{~s}, 1 \mathrm{H}), 8.13(\mathrm{~d}, J=7.3 \mathrm{~Hz}, 1 \mathrm{H}), 7.76(\mathrm{~s}, 1 \mathrm{H})$, $7.64(\mathrm{~s}, 1 \mathrm{H}), 7.60(\mathrm{~s}, 1 \mathrm{H}), 7.27(\mathrm{~s}, 1 \mathrm{H}), 7.22(\mathrm{~s}, 1 \mathrm{H}), 6.93(\mathrm{~s}, 1 \mathrm{H}), 4.08$ (s, 3H), $4.06(\mathrm{~s}, 3 \mathrm{H}), 3.82(\mathrm{~d}, J=6.8 \mathrm{~Hz}, 2 \mathrm{H}), 1.28(\mathrm{~s}, 1 \mathrm{H}), 0.64(\mathrm{~d}, J=$ $7.8 \mathrm{~Hz}, 2 \mathrm{H}), 0.34(\mathrm{~d}, J=4.0 \mathrm{~Hz}, 2 \mathrm{H})$. MS (ESI) $m / z:[\mathrm{M}+\mathrm{H}]^{+}$calcd for $\mathrm{C}_{26} \mathrm{H}_{24} \mathrm{ClN}_{4} \mathrm{O}_{4}{ }^{+} 491.15$, found 491.3 .

3-(3-Chloro-5-(3,3,3-trifluoropropoxy)phenyl)-5-(2,4-dimethoxypyrimidin-5-yl)-2H-[1,3'bipyridin]-2-one (S7c)

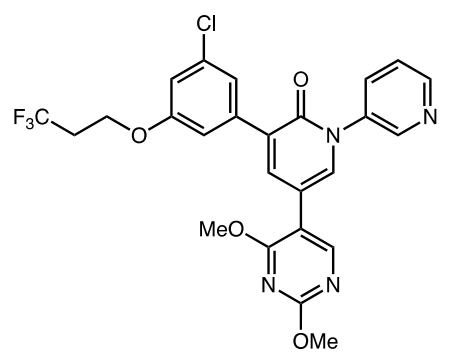

General Procedure C was employed using S6 and 1-bromo-3-chloro5-(3,3,3-trifluoropropoxy) benzene (S13f) to afford the title compound as a white solid (66 mg, 62\% yield). ${ }^{1} \mathbf{H}$ NMR $(400 \mathrm{MHz}$, $\left.\mathrm{CDCl}_{3}\right) \delta 8.80(\mathrm{~s}, 1 \mathrm{H}), 8.74(\mathrm{~d}, J=4.5 \mathrm{~Hz}, 1 \mathrm{H}), 8.30(\mathrm{~s}, 1 \mathrm{H}), 8.07(\mathrm{~d}$, $J=8.2 \mathrm{~Hz}, 1 \mathrm{H}), 7.77(\mathrm{~s}, 1 \mathrm{H}), 7.64-7.57(\mathrm{~m}, 2 \mathrm{H}), 7.31(\mathrm{~s}, 1 \mathrm{H}), 7.27$ (s, 1H), $6.93(\mathrm{~s}, 1 \mathrm{H}), 4.22(\mathrm{t}, J=6.5 \mathrm{~Hz}, 2 \mathrm{H}), 4.08(\mathrm{~s}, 3 \mathrm{H}), 4.06(\mathrm{~s}$, $3 \mathrm{H}), 2.71-2.54(\mathrm{~m}, 2 \mathrm{H})$. MS $(\mathrm{ESI}) \mathrm{m} / \mathrm{z}:[\mathrm{M}+\mathrm{H}]^{+}$calcd for

$\mathrm{C}_{25} \mathrm{H}_{21} \mathrm{ClF}_{3} \mathrm{~N}_{4} \mathrm{O}_{4}{ }^{+}$533.12, found 533.2.

3-(3-Chloro-5-((5-methyloxazol-4-yl)methoxy)phenyl)-5-(2,4-dimethoxypyrimidin-5-yl)-2H[1,3'-bipyridin]-2-one (S7d)

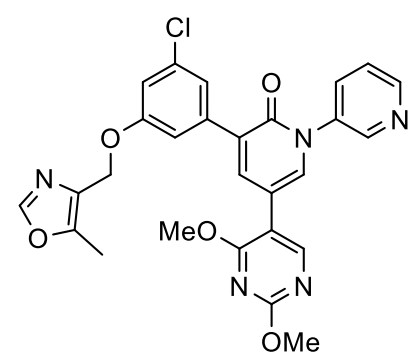

General Procedure C was employed using S6 and 4-((3-bromo-5chlorophenoxy)methyl)-5-methyloxazole (S13a) to afford the title compound as a white solid (56 mg, $53 \%$ yield). ${ }^{1} \mathbf{H}$ NMR $(400 \mathrm{MHz}$, $\left.\mathrm{CDCl}_{3}\right) \delta 8.75(\mathrm{~s}, 1 \mathrm{H}), 8.72(\mathrm{~d}, J=4.2 \mathrm{~Hz}, 1 \mathrm{H}), 8.28(\mathrm{~s}, 1 \mathrm{H}), 7.96(\mathrm{~d}, J$ $=8.1 \mathrm{~Hz}, 1 \mathrm{H}), 7.79-7.74(\mathrm{~m}, 2 \mathrm{H}), 7.58(\mathrm{~d}, J=2.2 \mathrm{~Hz}, 1 \mathrm{H}), 7.52(\mathrm{dd}$, $J=8.1,4.8 \mathrm{~Hz}, 1 \mathrm{H}), 7.38-7.35(\mathrm{~m}, 1 \mathrm{H}), 7.34(\mathrm{~d}, J=2.0 \mathrm{~Hz}, 1 \mathrm{H}), 7.01$ $(\mathrm{t}, J=1.9 \mathrm{~Hz}, 1 \mathrm{H}), 4.97(\mathrm{~s}, 2 \mathrm{H}), 4.07(\mathrm{~s}, 3 \mathrm{H}), 4.05(\mathrm{~s}, 3 \mathrm{H}), 2.37(\mathrm{~s}, 3 \mathrm{H})$.

MS (ESI) $m / z:[\mathrm{M}+\mathrm{H}]^{+}$calcd for $\mathrm{C}_{27} \mathrm{H}_{23} \mathrm{ClN}_{5} \mathrm{O}_{5}{ }^{+} 532.14$, found 532.2.

3-(3-Chloro-5-((4-methyloxazol-5-yl)methoxy)phenyl)-5-(2,4-dimethoxypyrimidin-5-yl)-2H[1,3'-bipyridin]-2-one (S7e)

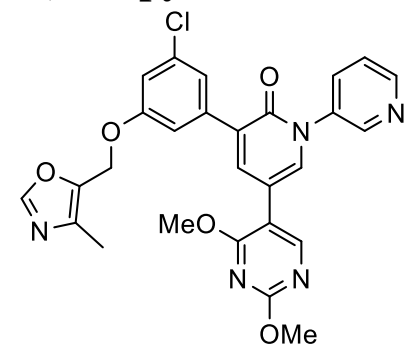

General Procedure C was employed using S6 and 5-((3-bromo-5chlorophenoxy)methyl)-4-methyloxazole (S13b) to afford the title compound as a white solid (52 mg, $49 \%$ yield). ${ }^{1} \mathbf{H}$ NMR $(400 \mathrm{MHz}$, $\left.\mathrm{CDCl}_{3}\right) \delta 8.76(\mathrm{~s}, 1 \mathrm{H}), 8.71(\mathrm{~d}, J=4.5 \mathrm{~Hz}, 1 \mathrm{H}), 8.26(\mathrm{~s}, 1 \mathrm{H}), 7.99(\mathrm{~d}, J$ $=8.0 \mathrm{~Hz}, 1 \mathrm{H}), 7.80(\mathrm{~s}, 1 \mathrm{H}), 7.75(\mathrm{~d}, J=2.1 \mathrm{~Hz}, 1 \mathrm{H}), 7.55(\mathrm{dt}, J=13.0$, $3.3 \mathrm{~Hz}, 2 \mathrm{H}), 7.32(\mathrm{~d}, J=1.6 \mathrm{~Hz}, 2 \mathrm{H}), 6.98(\mathrm{~s}, 1 \mathrm{H}), 5.01(\mathrm{~s}, 2 \mathrm{H}), 4.05(\mathrm{~s}$, 
$3 \mathrm{H}), 4.03(\mathrm{~s}, 3 \mathrm{H}), 2.21(\mathrm{~s}, 3 \mathrm{H})$. MS (ESI) $\mathrm{m} / z$ : $[\mathrm{M}+\mathrm{H}]^{+}$calcd for $\mathrm{C}_{27} \mathrm{H}_{23} \mathrm{ClN}_{5} \mathrm{O}_{5}{ }^{+} 532.14$, found 532.2 .

3-(3-Chloro-5-((2-chlorothiophen-3-yl)methoxy)phenyl)-5-(2,4-dimethoxypyrimidin-5-yl)2H-[1,3'-bipyridin]-2-one (S7f)

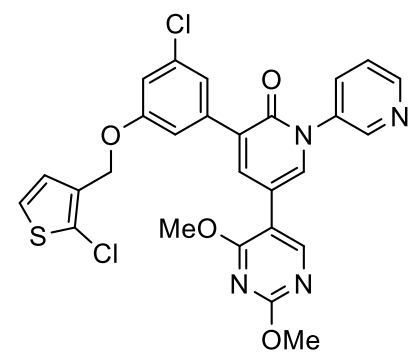

General Procedure C was employed using S6 and 3-((3-bromo-5chlorophenoxy)methyl)-2-chlorothiophene (S13i) to afford the title compound as a white solid (70 mg, $62 \%$ yield). ${ }^{1} \mathbf{H}$ NMR $(400 \mathrm{MHz}$, $\left.\mathrm{CDCl}_{3}\right) \delta 8.78(\mathrm{~s}, 1 \mathrm{H}), 8.73(\mathrm{~d}, J=4.2 \mathrm{~Hz}, 1 \mathrm{H}), 8.29(\mathrm{~s}, 1 \mathrm{H}), 8.03(\mathrm{~d}, J$ $=8.0 \mathrm{~Hz}, 1 \mathrm{H}), 7.75(\mathrm{~s}, 1 \mathrm{H}), 7.58(\mathrm{~d}, J=9.1 \mathrm{~Hz}, 2 \mathrm{H}), 7.34(\mathrm{~s}, 1 \mathrm{H}), 7.30$ $(\mathrm{s}, 1 \mathrm{H}), 7.15-7.10(\mathrm{~m}, 1 \mathrm{H}), 7.07-7.02(\mathrm{~m}, 1 \mathrm{H}), 7.02-6.96(\mathrm{~m}, 1 \mathrm{H})$, $5.03(\mathrm{~s}, 2 \mathrm{H}), 4.07(\mathrm{~s}, 3 \mathrm{H}), 4.05(\mathrm{~s}, 3 \mathrm{H})$. MS (ESI) $m / z:[\mathrm{M}+\mathrm{H}]^{+}$calcd for $\mathrm{C}_{27} \mathrm{H}_{21} \mathrm{Cl}_{2} \mathrm{~N}_{4} \mathrm{O}_{4} \mathrm{~S}^{+}$567.07, found 567.1.

3-(3-Chloro-5-((5-methylthiazol-4-yl)methoxy)phenyl)-5-(2,4-dimethoxypyrimidin-5-yl)2H-[1,3'-bipyridin]-2-one (S7g)

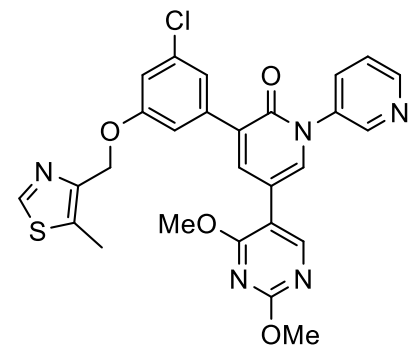

General Procedure C was employed using S6 and 4-((3-bromo-5chlorophenoxy)methyl)-5-methylthiazole (S13c) to afford the title compound as a white solid (63 mg, $58 \%$ yield). ${ }^{1} \mathbf{H}$ NMR $(400 \mathrm{MHz}$, $\left.\mathrm{CDCl}_{3}\right) \delta 8.73(\mathrm{~s}, 1 \mathrm{H}), 8.69(\mathrm{~d}, J=4.2 \mathrm{~Hz}, 1 \mathrm{H}), 8.58(\mathrm{~s}, 1 \mathrm{H}), 8.26(\mathrm{~s}$, $1 \mathrm{H}), 7.92(\mathrm{~d}, J=8.2 \mathrm{~Hz}, 1 \mathrm{H}), 7.74(\mathrm{~d}, J=2.4 \mathrm{~Hz}, 1 \mathrm{H}), 7.56(\mathrm{~d}, J=2.4$ $\mathrm{Hz}, 1 \mathrm{H}), 7.48$ (dd, $J=8.1,4.9 \mathrm{~Hz}, 1 \mathrm{H}), 7.35$ (s, 1H), 7.32 (s, 1H), 7.02 $(\mathrm{t}, J=1.9 \mathrm{~Hz}, 1 \mathrm{H}), 5.16(\mathrm{~s}, 2 \mathrm{H}), 4.04(\mathrm{~s}, 3 \mathrm{H}), 4.02(\mathrm{~s}, 3 \mathrm{H}), 2.50(\mathrm{~s}, 3 \mathrm{H})$.

MS (ESI) $m / z$ : $[\mathrm{M}+\mathrm{H}]^{+}$calcd for $\mathrm{C}_{27} \mathrm{H}_{23} \mathrm{ClN}_{5} \mathrm{O}_{4} \mathrm{~S}^{+}$548.12, found 548.1.

\section{3-(3-Chloro-5-((4-(trifluoromethyl)oxazol-5-yl)methoxy)phenyl)-5-(2,4-dimethoxy- pyrimidin-5-yl)-2H-[1,3'-bipyridin]-2-one (S7h)}

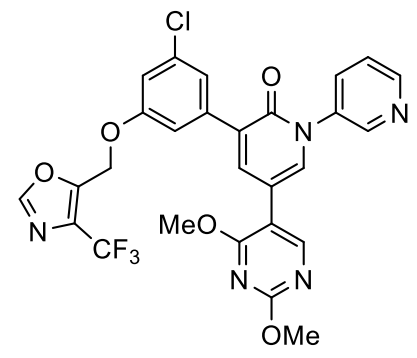

General Procedure C was employed using S6 and 5-((3-bromo-5-

chlorophenoxy)methyl)-4-(trifluoromethyl)oxazole (S13d) to afford the title compound as a white solid (50 mg, $43 \%$ yield). ${ }^{1} \mathbf{H}$ NMR (400 $\left.\mathrm{MHz}, \mathrm{CDCl}_{3}\right) \delta 8.71(\mathrm{dd}, J=6.6,3.6 \mathrm{~Hz}, 2 \mathrm{H}), 8.25(\mathrm{~s}, 1 \mathrm{H}), 7.95(\mathrm{~s}, 1 \mathrm{H})$, $7.90(\mathrm{~d}, J=8.2 \mathrm{~Hz}, 1 \mathrm{H}), 7.75(\mathrm{~d}, J=2.2 \mathrm{~Hz}, 1 \mathrm{H}), 7.56(\mathrm{~d}, J=2.1 \mathrm{~Hz}$, $1 \mathrm{H}), 7.48$ (dd, $J=8.1,4.8 \mathrm{~Hz}, 1 \mathrm{H}), 7.35$ (d, $J=2.6 \mathrm{~Hz}, 2 \mathrm{H}), 6.97$ (s, 1H), $5.18(\mathrm{~s}, 2 \mathrm{H}), 4.05$ (s, 3H), 4.03 (s, 3H). ). ${ }^{19}$ F NMR (376 MHz, DMSO) $\delta$-62.51. MS (ESI) $m / z$ : $[\mathrm{M}+\mathrm{H}]^{+}$calcd for $\mathrm{C}_{27} \mathrm{H}_{20} \mathrm{ClF}_{3} \mathrm{~N}_{5} \mathrm{O}_{5}{ }^{+}$586.11, found 586.1. 


\section{3-(3-Chloro-5-((4-(trifluoromethyl)thiazol-5-yl)methoxy)phenyl)-5-(2,4-dimethoxy-}

pyrimidin-5-yl)-2H-[1,3'-bipyridin]-2-one (S7i)

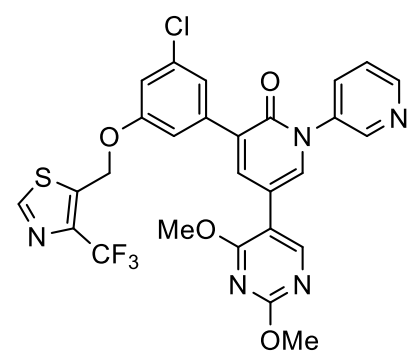

602.2 .

General Procedure C was employed using S6 and 5-((3-bromo-5chlorophenoxy)methyl)-4-(trifluoromethyl)oxazole (S13d) to afford the title compound as a white solid (56 mg, $47 \%$ yield). ${ }^{1} \mathbf{H}$ NMR (400 $\left.\mathrm{MHz}, \mathrm{CDCl}_{3}\right) \delta 8.80(\mathrm{~s}, 1 \mathrm{H}), 8.71(\mathrm{~d}, J=6.6 \mathrm{~Hz}, 2 \mathrm{H}), 8.25(\mathrm{~s}, 1 \mathrm{H}), 7.90$ $(\mathrm{d}, J=8.1 \mathrm{~Hz}, 1 \mathrm{H}), 7.75(\mathrm{~s}, 1 \mathrm{H}), 7.56(\mathrm{~d}, J=1.3 \mathrm{~Hz}, 1 \mathrm{H}), 7.51-7.44$ (m, 1H), $7.35(\mathrm{~s}, 2 \mathrm{H}), 6.98(\mathrm{~s}, 1 \mathrm{H}), 5.41(\mathrm{~s}, 2 \mathrm{H}), 4.05(\mathrm{~s}, 3 \mathrm{H}), 4.03$ (s, $3 \mathrm{H})$. MS (ESI) $m / z$ : $[\mathrm{M}+\mathrm{H}]^{+}$calcd for $\mathrm{C}_{27} \mathrm{H}_{20} \mathrm{ClF}_{3} \mathrm{~N}_{5} \mathrm{O}_{4} \mathrm{~S}^{+} 602.09$, found

3-(3-Chloro-5-((2-chlorobenzyl)oxy)-4-fluorophenyl)-5-(2,4-dimethoxypyrimidin-5-yl)-2H[1,3'-bipyridin]-2-one (S7j)<smiles>COc1ncc(-c2cc(-c3cc(Cl)c(F)c(OCc4ccccc4Cl)c3)c(=O)n(-c3cccnc3)c2)c(OC)n1</smiles>

$\mathrm{C}_{29} \mathrm{H}_{22} \mathrm{Cl}_{2} \mathrm{~N}_{4} \mathrm{O}_{4}{ }^{+}$579.10, found 579.2.

General Procedure C was employed using S6 and 5-bromo-1-chloro-3((2-chlorobenzyl)oxy)-2-fluorobenzene $(\mathbf{S 1 3 j})$ to afford the title compound as a white solid (77.4 $\mathrm{mg}, 67 \%$ yield). ${ }^{1} \mathbf{H}$ NMR $(400 \mathrm{MHz}$, $\left.\mathrm{CDCl}_{3}\right) \delta 8.81(\mathrm{~s}, 1 \mathrm{H}), 8.75(\mathrm{~d}, J=4.2 \mathrm{~Hz}, 1 \mathrm{H}), 8.30(\mathrm{~s}, 1 \mathrm{H}), 8.08(\mathrm{~d}, J$ $=8.2 \mathrm{~Hz}, 1 \mathrm{H}), 7.70(\mathrm{~d}, J=2.1 \mathrm{~Hz}, 1 \mathrm{H}), 7.62-7.58(\mathrm{~m}, 2 \mathrm{H}), 7.54(\mathrm{dd}, J$ $=7.4,1.5 \mathrm{~Hz}, 1 \mathrm{H}), 7.43-7.37(\mathrm{~m}, 3 \mathrm{H}), 7.30(\mathrm{td}, J=6.9,1.8 \mathrm{~Hz}, 2 \mathrm{H})$, $5.26(\mathrm{~s}, 2 \mathrm{H}), 4.08(\mathrm{~s}, 3 \mathrm{H}), 4.06(\mathrm{~s}, 3 \mathrm{H})$. MS (ESI) $\mathrm{m} / \mathrm{z}:[\mathrm{M}+\mathrm{H}]^{+}$calcd for

2-(3-(3-Chloro-5-propoxyphenyl)-2-oxo-2H-[1,3'-bipyridin]-5-yl)benzonitrile (2)<smiles>CCCOc1cc(Cl)cc(-c2cc(-c3ccccc3C)cn(-c3cccnc3)c2=O)c1</smiles>

This compound was previously reported. ${ }^{1}$

2-(3-(3-Chloro-5-(cyclopropylmethoxy)phenyl)-2-oxo-2H-[1,3'-bipyridin]-5-yl)benzonitrile (3)<smiles>N#Cc1ccccc1-c1cc(-c2cc(Cl)cc(OCC3CC3)c2)c(=O)n(-c2cccnc2)c1</smiles>

This compound was previously reported. ${ }^{1}$ 
2-(3-(3-Chloro-5-(3,3,3-trifluoropropoxy)phenyl)-2-oxo-2H-[1,3'-bipyridin]-5-

yl)benzonitrile (4)<smiles>N#Cc1ccccc1-c1cc(-c2cc(Cl)cc(OCCCF)c2)c(=O)n(-c2cccnc2)c1</smiles>

This compound was previously reported. ${ }^{1}$

5-(3-(3-Chloro-5-propoxyphenyl)-2-oxo-2H-[1,3'-bipyridin]-5-yl)pyrimidine-2,4(1H,3H)dione (5)<smiles>CCCOc1cc(Cl)cc(-c2cc(-c3c[nH]c(=O)[nH]c3=O)cn(-c3cccnc3)c2=O)c1</smiles>

This compound was previously reported. ${ }^{1}$

5-(3-(3-Chloro-5-(cyclopropylmethoxy)phenyl)-2-oxo-2H-[1,3'-bipyridin]-5-yl)pyrimidine2,4(1H,3H)-dione (6)<smiles>O=c1[nH]cc(-c2cc(-c3cc(Cl)cc(OCC4CC4)c3)c(=O)n(-c3cccnc3)c2)c(=O)[nH]1</smiles>

This compound was previously reported. ${ }^{1}$

5-(3-(3-Chloro-5-(3,3,3-trifluoropropoxy)phenyl)-2-oxo-2H-[1,3'-bipyridin]-5-yl)pyrimidine $-2,4(1 H, 3 H)$-dione (7)<smiles>O=c1cc(-c2cc(-c3cc(Cl)cc(OCCC(F)(F)F)c3)c(=O)n(-c3cccnc3)c2)cc[nH]1</smiles>

This compound was previously reported. ${ }^{1}$ 


\section{2-(3-(3-Chloro-5-(cyclopentylmethoxy)phenyl)-2-oxo-2H-[1,3'-bipyridin]-5-yl)benzonitrile}

(8)

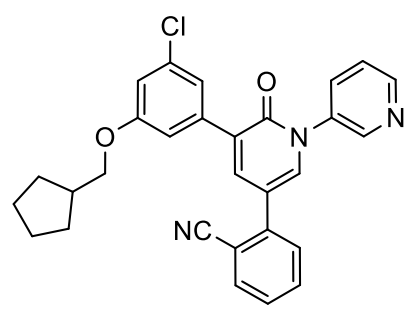

General Procedure C was employed using 2-(3-bromo-2-oxo-2H-[1,3'bipyridin]-5-yl)benzonitrile (S17, $50.0 \mathrm{mg}, 0.14 \mathrm{mmol}, 1.0$ equiv) and S13h (41.5 mg, $0.15 \mathrm{mmol}, 1.1$ equiv). Purification was accomplished using normal phase column chromatography (SNAP Ultra 25g, gradient $=0-100 \% \mathrm{EtOAc} / \mathrm{Hex}$ over $10 \mathrm{CV}$, then $100 \% \mathrm{EtOAc} / \mathrm{Hex}$ over $4 \mathrm{CV}$ ) followed by reverse phase column chromatography (SNAP

Ultra $\mathrm{C} 1860 \mathrm{~g}$, gradient $=0-100 \% \mathrm{MeCN} / \mathrm{H}_{2} \mathrm{O}$ over $\left.12 \mathrm{CV}\right)$ to afford $27.7 \mathrm{mg}(41 \%$ yield) of a white solid. ${ }^{1} \mathbf{H}$ NMR $\left(600 \mathrm{MHz}, \mathrm{DMSO}-d_{6}\right) \delta 8.82(\mathrm{~s}, 1 \mathrm{H}), 8.70(\mathrm{~s}, 1 \mathrm{H}), 8.21(\mathrm{~d}, J=2.6 \mathrm{~Hz}, 1 \mathrm{H})$, $8.17(\mathrm{~d}, J=2.6 \mathrm{~Hz}, 1 \mathrm{H}), 8.08(\mathrm{ddd}, J=8.2,2.6,1.4 \mathrm{~Hz}, 1 \mathrm{H}), 7.96(\mathrm{dd}, J=7.8,1.2 \mathrm{~Hz}, 1 \mathrm{H}), 7.84$ $(\mathrm{dd}, J=7.9,1.1 \mathrm{~Hz}, 1 \mathrm{H}), 7.78(\mathrm{td}, J=7.7,1.4 \mathrm{~Hz}, 1 \mathrm{H}), 7.63(\mathrm{dd}, J=8.3,4.5 \mathrm{~Hz}, 1 \mathrm{H}), 7.57$ (td, $J$ $=7.6,1.3 \mathrm{~Hz}, 1 \mathrm{H}), 7.47(\mathrm{t}, J=1.7 \mathrm{~Hz}, 1 \mathrm{H}), 7.36(\mathrm{t}, J=1.9 \mathrm{~Hz}, 1 \mathrm{H}), 7.02(\mathrm{t}, J=2.1 \mathrm{~Hz}, 1 \mathrm{H}), 3.90$ $(\mathrm{d}, J=7.0 \mathrm{~Hz}, 2 \mathrm{H}), 2.30(\mathrm{p}, J=7.4 \mathrm{~Hz}, 1 \mathrm{H}), 1.81-1.71(\mathrm{~m}, 2 \mathrm{H}), 1.60(\mathrm{qd}, J=9.9,8.1,2.9 \mathrm{~Hz}$, 2H), $1.57-1.48(\mathrm{~m}, 2 \mathrm{H}), 1.32(\mathrm{ddt}, J=13.6,7.8,4.2 \mathrm{~Hz}, 2 \mathrm{H}) .{ }^{13} \mathbf{C ~ N M R}\left(151 \mathrm{MHz}, \mathrm{CDCl}_{3}\right) \delta$ 160.2 , 160.0, 140.1, 139.2, 138.1, 136.6, 134.8, 134.5, 134.1, 133.5, 132.2, 132.1, 131.6, 129.3, $128.8,128.7,128.5,121.0,118.6,117.5,115.3,113.6,111.1,72.7,39.1,29.5,25.6$. HRMS $\left(\mathrm{ES}^{+}\right)$ $m / z:[\mathrm{M}+\mathrm{H}]^{+}$calcd for $\mathrm{C}_{29} \mathrm{H}_{25} \mathrm{ClN}_{3} \mathrm{O}_{2}{ }^{+} 482.1630$, found 482.1625 .

\section{2-(3-(3-Chloro-5-((5-methyloxazol-4-yl)methoxy)phenyl)-2-oxo-2H-[1,3'-bipyridin]-5-yl)} benzonitrile (9)

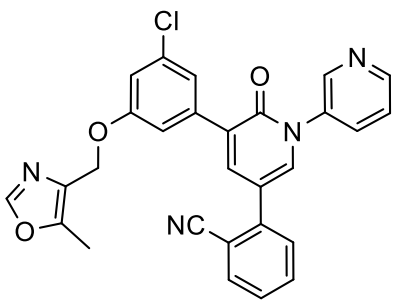

General Procedure C was employed using 2-(3-bromo-2-oxo-2H-[1,3'bipyridin]-5-yl)benzonitrile (S17, $35.2 \mathrm{mg}, 0.10 \mathrm{mmol}, 1.0$ equiv) and 4-((3-bromo-5-chlorophenoxy)-methyl)-5-methyloxazole (S13a, 33.3 $\mathrm{mg}, 0.11 \mathrm{mmol}, 1.1$ equiv). Purification was accomplished using reverse phase column chromatography (SNAP Ultra C18 60g, gradient $=0-60 \%$ $\mathrm{MeCN} / \mathrm{H}_{2} \mathrm{O}$ over $8 \mathrm{CV}$, then $60 \% \mathrm{MeCN} / \mathrm{H}_{2} \mathrm{O}$ over $2 \mathrm{CV}$, then $60-100 \%$ $\mathrm{MeCN} / \mathrm{H}_{2} \mathrm{O}$ over $3 \mathrm{CV}$ ) to afford $22.7 \mathrm{mg}$ (46\% yield) of a pale-pink solid. ${ }^{1} \mathbf{H}$ NMR (400 MHz, $\left.\mathrm{CDCl}_{3}\right) \delta 8.81(\mathrm{~s}, 1 \mathrm{H}), 8.71(\mathrm{~d}, J=4.8 \mathrm{~Hz}, 1 \mathrm{H}), 7.95(\mathrm{ddd}, J=8.2,2.6,1.4 \mathrm{~Hz}, 1 \mathrm{H}), 7.83(\mathrm{~d}, J=$ $2.7 \mathrm{~Hz}, 1 \mathrm{H}), 7.79$ (dd, $J=7.8,1.3 \mathrm{~Hz}, 1 \mathrm{H}), 7.75(\mathrm{~s}, 1 \mathrm{H}), 7.71(\mathrm{~d}, J=2.7 \mathrm{~Hz}, 1 \mathrm{H}), 7.68(\mathrm{dd}, J=$ 7.7, $1.4 \mathrm{~Hz}, 1 \mathrm{H}), 7.55(\mathrm{dd}, J=8.0,1.1 \mathrm{~Hz}, 1 \mathrm{H}), 7.52-7.43(\mathrm{~m}, 3 \mathrm{H}), 7.40(\mathrm{t}, J=1.6 \mathrm{~Hz}, 1 \mathrm{H}), 7.37$ $(\mathrm{dd}, J=2.4,1.5 \mathrm{~Hz}, 1 \mathrm{H}), 4.96(\mathrm{~s}, 2 \mathrm{H}), 2.37$ (s, 3H). ${ }^{13} \mathbf{C ~ N M R}\left(101 \mathrm{MHz}, \mathrm{CDCl}_{3}\right) \delta 160.1,159.1$, 149.9 , 149.5, 147.7, 147.4, 140.0, 139.4, 138.2, 137.5, 136.7, 134.9, 134.7, 134.1, 133.6, 131.4, 130.0, 129.3, 128.5, 124.0, 121.8, 118.6, 117.5, 115.8, 113.7, 111.1, 62.5, 10.4. HRMS (ES $\left.{ }^{+}\right) \mathrm{m} / z$ : $[\mathrm{M}+\mathrm{H}]^{+}$calcd for $\mathrm{C}_{28} \mathrm{H}_{20} \mathrm{ClN}_{4} \mathrm{O}_{3}{ }^{+} 495.1218$, found 495.1215 . 


\section{5-(3-(3-Chloro-5-((5-methyloxazol-4-yl)methoxy)phenyl)-2-oxo-2H-[1,3'-bipyridin]-5-}

yl)pyrimidine-2,4(1H,3H)-dione (10)

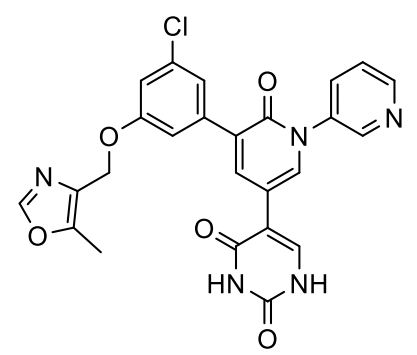

General Procedure D was employed using S7d to afford 18 (45 mg, 85\% yield). ${ }^{1}$ H NMR (400 MHz, DMSO- $\left.d_{6}\right) \delta 11.24$ (s, 2H), 8.72 (d, $J=2.2$ $\mathrm{Hz}, 1 \mathrm{H}), 8.63(\mathrm{~d}, J=4.0 \mathrm{~Hz}, 1 \mathrm{H}), 8.20(\mathrm{~s}, 1 \mathrm{H}), 8.04(\mathrm{~d}, J=2.2 \mathrm{~Hz}, 1 \mathrm{H})$, $8.02-7.95(\mathrm{~m}, 2 \mathrm{H}), 7.88(\mathrm{~s}, 1 \mathrm{H}), 7.57(\mathrm{dd}, J=8.1,4.8 \mathrm{~Hz}, 1 \mathrm{H}), 7.43$ (s, 1H), 7.33 (s, 1H), 7.10 (s, 1H), 4.99 (s, 2H), 2.34 (s, 3H). ${ }^{13}$ C NMR (101 $\left.\mathrm{MHz}, \mathrm{DMSO}-d_{6}\right) \delta 163.71,159.65,159.14,151.70,150.90,149.59$, $148.06,147.75,140.43,140.16,139.49,138.09,136.72,135.25,133.57$, $129.99,128.13,124.31,121.36,114.69,114.33,112.79,107.59,62.03,10.14$. HRMS (ESI) $m / z$ : $[\mathrm{M}+\mathrm{H}]^{+}$calcd for $\mathrm{C}_{25} \mathrm{H}_{19} \mathrm{ClN}_{5} \mathrm{O}_{5}{ }^{+}$504.1069, found 504.1068.

5-(3-(3-Chloro-5-((4-methyloxazol-5-yl)methoxy)phenyl)-2-oxo-2H-[1,3'-bipyridin]-5yl)pyrimidine-2,4(1H,3H)-dione (11)

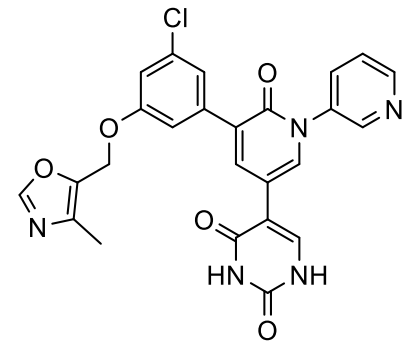

General Procedure D was employed using S7e to afford 11 (17 mg, 35\% yield). ${ }^{1} \mathbf{H}$ NMR (400 MHz, DMSO-d $) \delta 11.30(\mathrm{~d}, J=25.2 \mathrm{~Hz}, 2 \mathrm{H})$, $8.72(\mathrm{~d}, J=2.3 \mathrm{~Hz}, 1 \mathrm{H}), 8.67-8.61(\mathrm{~m}, 1 \mathrm{H}), 8.28(\mathrm{~s}, 1 \mathrm{H}), 8.04(\mathrm{~d}, J=$ $2.5 \mathrm{~Hz}, 1 \mathrm{H}), 8.03-7.96(\mathrm{~m}, 2 \mathrm{H}), 7.88(\mathrm{~s}, 1 \mathrm{H}), 7.57(\mathrm{dd}, J=8.1,4.8 \mathrm{~Hz}$, $1 \mathrm{H}), 7.46(\mathrm{t}, J=1.5 \mathrm{~Hz}, 1 \mathrm{H}), 7.36-7.31(\mathrm{~m}, 1 \mathrm{H}), 7.12(\mathrm{t}, J=2.0 \mathrm{~Hz}$, $1 \mathrm{H}), 5.18(\mathrm{~s}, 2 \mathrm{H}), 2.14(\mathrm{~s}, 3 \mathrm{H}) .{ }^{13} \mathrm{C}$ NMR (101 MHz, DMSO-d 6$) \delta$ $163.66,159.65,158.72,152.27,151.35,149.62,148.05,142.12,140.25$, $139.77,139.53,138.04,136.92,135.31,135.26,133.61,128.02,124.32,121.67,114.77,114.35$, 112.60, 107.83, 59.45, 11.40. HRMS (ESI) $m / z$ : $[\mathrm{M}+\mathrm{H}]^{+}$calcd for $\mathrm{C}_{25} \mathrm{H}_{19} \mathrm{ClN}_{5} \mathrm{O}_{5}{ }^{+} 504.1069$, found 504.1074 .

5-(3-(3-Chloro-5-((2-chlorothiophen-3-yl)methoxy)phenyl)-2-oxo-2H-[1,3'-bipyridin]-5yl)pyrimidine-2,4(1H,3H)-dione (12)

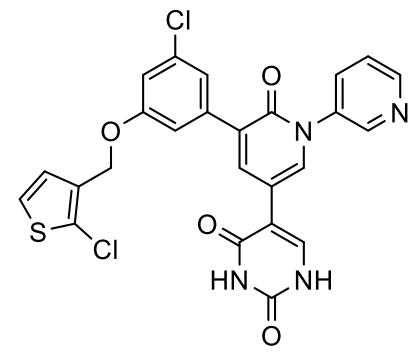

General Procedure D was employed using S7f to afford $12(57 \mathrm{mg}, 85 \%$ yield). ${ }^{1} \mathbf{H}$ NMR $\left(600 \mathrm{MHz}, \mathrm{DMSO}-d_{6}\right) \delta 11.26(\mathrm{~s}, 2 \mathrm{H}), 8.68(\mathrm{~s}, 1 \mathrm{H})$, $8.65-8.55(\mathrm{~m}, 1 \mathrm{H}), 8.01(\mathrm{~s}, 1 \mathrm{H}), 7.98-7.92(\mathrm{~m}, 2 \mathrm{H}), 7.84(\mathrm{~d}, J=1.9$ $\mathrm{Hz}, 1 \mathrm{H}), 7.54$ (dt, $J=7.4,3.4 \mathrm{~Hz}, 1 \mathrm{H}), 7.43(\mathrm{dd}, J=5.5,2.0 \mathrm{~Hz}, 1 \mathrm{H})$, $7.41(\mathrm{~s}, 1 \mathrm{H}), 7.33(\mathrm{~s}, 1 \mathrm{H}), 7.15-7.08(\mathrm{~m}, 1 \mathrm{H}), 7.08-7.02(\mathrm{~m}, 1 \mathrm{H}), 5.01$ $(\mathrm{s}, 2 \mathrm{H}) .{ }^{13} \mathrm{C}$ NMR (151 MHz, DMSO-d $) \delta 163.24,159.23,158.61$, 151.01, 149.18, 147.63, 139.81, 139.51, 139.14, 137.63, 136.44, 134.83, 133.93, 133.24, 128.38, 127.60, 127.14, 124.79, 123.88, 121.12, 114.13, 113.82, 112.22, 107.35, 62.72. HRMS (ESI) $m / z$ : $[\mathrm{M}+\mathrm{H}]^{+}$calcd for $\mathrm{C}_{25} \mathrm{H}_{17} \mathrm{Cl}_{2} \mathrm{~N}_{4} \mathrm{O}_{4} \mathrm{~S}^{+}$539.0342, found 539.0347. 
5-(3-(3-Chloro-5-((5-methylthiazol-4-yl)methoxy)phenyl)-2-oxo-2H-[1,3'-bipyridin]-5yl)pyrimidine-2,4(1H,3H)-dione (13)

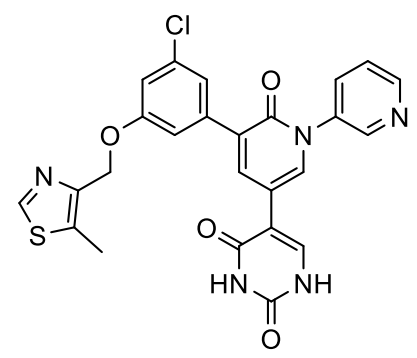

General Procedure D was employed using S7g to afford 13 (48 mg, $80 \%$ yield). ${ }^{1} \mathbf{H}$ NMR (600 MHz, DMSO- $\left.d_{6}\right) \delta 11.28(\mathrm{~s}, 2 \mathrm{H}), 8.87$ (s, $1 \mathrm{H}), 8.73(\mathrm{~s}, 1 \mathrm{H}), 8.64(\mathrm{~s}, 1 \mathrm{H}), 8.06(\mathrm{~s}, 1 \mathrm{H}), 8.00(\mathrm{~d}, J=8.0 \mathrm{~Hz}, 2 \mathrm{H})$, $7.89(\mathrm{~s}, 1 \mathrm{H}), 7.61-7.55(\mathrm{~m}, 1 \mathrm{H}), 7.44(\mathrm{~s}, 1 \mathrm{H}), 7.37(\mathrm{~s}, 1 \mathrm{H}), 7.14(\mathrm{~s}$, 1H), $5.18(\mathrm{~s}, 2 \mathrm{H}), 2.48(\mathrm{~s}, 3 \mathrm{H}) .{ }^{13} \mathrm{C}$ NMR (151 MHz, DMSO-d 6 ) $\delta$ $163.69,159.66,159.31,151.57,151.35,149.60,148.06,147.86,140.17$, $139.49,138.09,136.77,135.26,133.58,133.36,128.15,124.31,121.35$, $114.70,114.27,112.72,107.69,64.03$, 11.14. HRMS (ESI) $m / z:[\mathrm{M}+\mathrm{H}]^{+}$calcd for $\mathrm{C}_{25} \mathrm{H}_{19} \mathrm{ClN}_{5} \mathrm{O}_{4} \mathrm{~S}^{+} 520.0841$, found 520.0839 .

5-(3-(3-Chloro-5-((4-(trifluoromethyl)oxazol-5-yl)methoxy)phenyl)-2-oxo-2H-[1,3'bipyridin]-5-yl)pyrimidine-2,4(1H,3H)-dione (14)

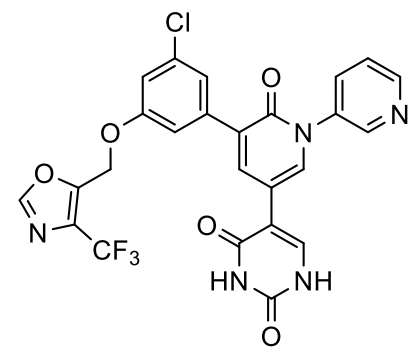

General Procedure D was employed using S7h to afford 14 (37 mg, $78 \%$ yield). ${ }^{1} \mathbf{H}$ NMR (600 MHz, DMSO- $\left.d_{6}\right) \delta 11.31(\mathrm{~s}, 2 \mathrm{H}), 8.73(\mathrm{~d}, J$ $=5.6 \mathrm{~Hz}, 2 \mathrm{H}), 8.64(\mathrm{~d}, J=4.5 \mathrm{~Hz}, 1 \mathrm{H}), 8.09-8.03(\mathrm{~m}, 1 \mathrm{H}), 8.02-7.97$ (m, 2H), $7.88(\mathrm{~s}, 1 \mathrm{H}), 7.57$ (dd, $J=7.8,5.0 \mathrm{~Hz}, 1 \mathrm{H}), 7.51$ (s, 1H), 7.39 $(\mathrm{s}, 1 \mathrm{H}), 7.16(\mathrm{~s}, 1 \mathrm{H}), 5.37(\mathrm{~s}, 2 \mathrm{H}) .{ }^{13} \mathrm{C}$ NMR (151 MHz, DMSO- $\left.d_{6}\right) \delta$ 163.67, 159.63, 158.33, 154.21, 151.41, 149.63, 148.07, 148.05, 140.32, 139.90, 139.69, 138.04, 136.98, 135.26, 133.75, 128.08, 127.83, 124.32, 122.26, 122.08, 120.31, 114.76, 114.38, 112.64, 107.78, 59.54. ${ }^{19}$ F NMR (376 MHz, DMSO) $\delta$ 61.41. HRMS (ESI) $m / z:[\mathrm{M}+\mathrm{H}]^{+}$calcd for $\mathrm{C}_{25} \mathrm{H}_{16} \mathrm{ClF}_{3} \mathrm{~N}_{5} \mathrm{O}_{5}{ }^{+}$558.0787, found 558.0785.

\section{5-(3-(3-Chloro-5-((4-(trifluoromethyl)thiazol-5-yl)methoxy)phenyl)-2-oxo-2H-[1,3'-} bipyridin]-5-yl)pyrimidine-2,4(1H,3H)-dione (15)

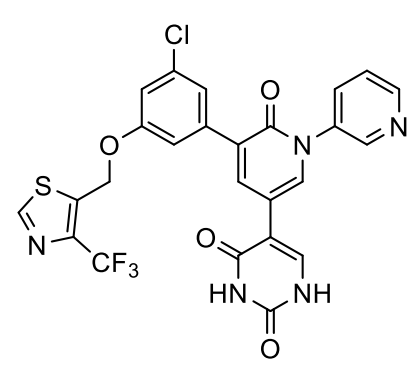

General Procedure D was employed using S7i to afford 15 (47 mg, 88\% yield). ${ }^{1} \mathbf{H}$ NMR (600 MHz, DMSO-d $d_{6} \delta 11.25$ (s, 2H), $9.23(\mathrm{~s}, 1 \mathrm{H})$, $8.72(\mathrm{~s}, 1 \mathrm{H}), 8.64(\mathrm{~d}, J=4.0 \mathrm{~Hz}, 1 \mathrm{H}), 8.05(\mathrm{~s}, 1 \mathrm{H}), 8.00(\mathrm{~d}, J=9.5 \mathrm{~Hz}$, 2H), $7.88(\mathrm{~s}, 1 \mathrm{H}), 7.63-7.55(\mathrm{~m}, 1 \mathrm{H}), 7.49(\mathrm{~s}, 1 \mathrm{H}), 7.40(\mathrm{~s}, 1 \mathrm{H}), 7.16$ $(\mathrm{s}, 1 \mathrm{H}), 5.55(\mathrm{~s}, 2 \mathrm{H}) .{ }^{13} \mathrm{C}$ NMR $\left(151 \mathrm{MHz}, \mathrm{DMSO}-d_{6}\right) \delta 163.72,159.63$, $158.28,156.72,151.69,149.62,148.06,140.44,140.32,139.85,139.71$, $139.62,138.52$, 138.06, 136.87, 135.27, 133.78, 127.82, 124.32, 122.43,

122.21, 120.64, 114.92, 114.41, 112.79, 107.61, 61.86. ${ }^{19}$ F NMR (376 MHz, DMSO) $\delta-59.65$. HRMS (ESI) $m / z$ : $[\mathrm{M}+\mathrm{H}]^{+}$calcd for $\mathrm{C}_{25} \mathrm{H}_{16} \mathrm{ClF}_{3} \mathrm{~N}_{5} \mathrm{O}_{4} \mathrm{~S}^{+} 574.0558$, found 574.0558 
5-(3-(3-Chloro-5-(cyclopropylmethoxy)phenyl)-2-oxo-2H-[1,3'-bipyridin]-5-yl)-1methylpyrimidine-2,4(1H,3H)-dione (16)

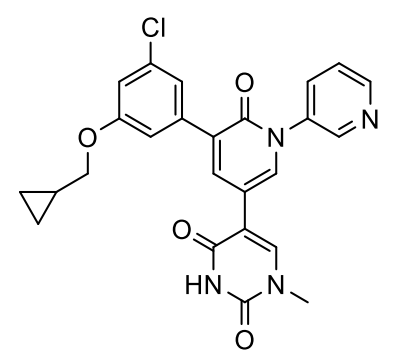

General Procedure E was employed using S7b to afford 16 (32 mg, 36\% yield). ${ }^{1} \mathbf{H}$ NMR (600 MHz, DMSO- $\left.d_{6}\right) \delta 11.57(\mathrm{~s}, 1 \mathrm{H}), 8.75(\mathrm{~s}, 1 \mathrm{H}), 8.68$ $(\mathrm{d}, J=4.6 \mathrm{~Hz}, 1 \mathrm{H}), 8.16(\mathrm{~s}, 1 \mathrm{H}), 8.12(\mathrm{~d}, J=1.8 \mathrm{~Hz}, 1 \mathrm{H}), 8.03$ (dd, $J=$ 4.8, $2.0 \mathrm{~Hz}, 2 \mathrm{H}), 7.61(\mathrm{dd}, J=8.1,4.8 \mathrm{~Hz}, 1 \mathrm{H}), 7.40(\mathrm{~s}, 1 \mathrm{H}), 7.29(\mathrm{~s}, 1 \mathrm{H})$, $7.00(\mathrm{~s}, 1 \mathrm{H}), 3.87(\mathrm{~d}, J=7.0 \mathrm{~Hz}, 2 \mathrm{H}), 3.32(\mathrm{~s}, 3 \mathrm{H}), 1.23(\mathrm{dt}, J=7.5,5.0$ $\mathrm{Hz}, 1 \mathrm{H}), 0.57$ (q, $J=5.0 \mathrm{~Hz}, 2 \mathrm{H}), 0.33$ (q, $J=4.8 \mathrm{~Hz}, 2 \mathrm{H}) .{ }^{13} \mathbf{C}$ NMR $\left(151 \mathrm{MHz}, \mathrm{DMSO}-d_{6}\right) \delta 163.17,159.64,159.61,150.97,149.70,148.03$, 143.90, 139.62, 139.41, 138.11, 136.69, 135.28, 133.67, 128.50, 124.38, 120.87, 114.40, 113.98, $112.42,107.81,73.01,35.85,10.45,3.56$. HRMS (ESI) $m / z$ : $[\mathrm{M}+\mathrm{H}]^{+}$calcd for $\mathrm{C}_{25} \mathrm{H}_{22} \mathrm{ClN}_{4} \mathrm{O}_{4}{ }^{+}$ 477.1324, found 477.1322

5-(3-(3-Chloro-5-(3,3,3-trifluoropropoxy)phenyl)-2-oxo-2H-[1,3'-bipyridin]-5-yl)-1methylpyrimidine-2,4(1H,3H)-dione (17)

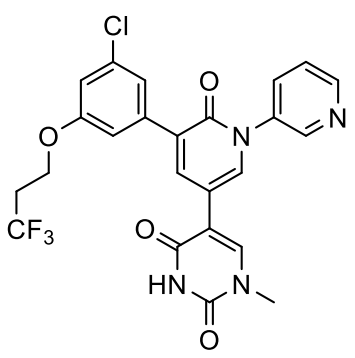

General Procedure E was employed using S7c to afford 17 (17 mg, 32\% yield). ${ }^{1} \mathbf{H}$ NMR (600 MHz, DMSO- $\left.d_{6}\right) \delta 11.53(\mathrm{~s}, 1 \mathrm{H}), 8.72(\mathrm{~s}, 1 \mathrm{H}), 8.69$ $-8.62(\mathrm{~m}, 1 \mathrm{H}), 8.14-8.11(\mathrm{~m}, 1 \mathrm{H}), 8.09(\mathrm{t}, J=2.5 \mathrm{~Hz}, 1 \mathrm{H}), 8.03-7.97$ (m, 2H), $7.58(\mathrm{td}, J=5.0,2.3 \mathrm{~Hz}, 1 \mathrm{H}), 7.43-7.40(\mathrm{~m}, 1 \mathrm{H}), 7.32-7.29$ (m, 1H), $7.07-7.04(\mathrm{~m}, 1 \mathrm{H}), 4.25(\mathrm{dt}, J=5.8,3.1 \mathrm{~Hz}, 2 \mathrm{H}), 3.29(\mathrm{~d}, J=$ $2.4 \mathrm{~Hz}, 3 \mathrm{H}), 2.86-2.70(\mathrm{~m}, 2 \mathrm{H}) .{ }^{13} \mathbf{C}$ NMR $\left(151 \mathrm{MHz}, \mathrm{DMSO}-d_{6}\right) \delta$ $163.18,163.07,159.64,158.83,150.97,150.88,149.71,148.02,143.91$, $139.75,139.54,138.08,136.77,135.27,133.82,128.29,124.36,121.54,114.49,114.06,112.45$, $112.42,107.83,61.91(\mathrm{~d}, J=3.4 \mathrm{~Hz}), 35.84,33.16(\mathrm{q}, J=27.9 \mathrm{~Hz}) .{ }^{19} \mathbf{F}$ NMR $(376 \mathrm{MHz}, \mathrm{DMSO})$ $\delta$-64.73 (t, $J=10.5 \mathrm{~Hz}$ ). HRMS (ESI) $m / z$ : $[\mathrm{M}+\mathrm{H}]^{+}$calcd for $\mathrm{C}_{24} \mathrm{H}_{19} \mathrm{ClF}_{3} \mathrm{~N}_{4} \mathrm{O}_{4}{ }^{+} 519.1041$, found 519.1041

\section{5-(3-(3-Chloro-5-((2-chlorobenzyl)oxy)-4-fluorophenyl)-2-oxo-2H-[1,3'-bipyridin]-5-} yl)pyrimidine-2,4(1H,3H)-dione (18)

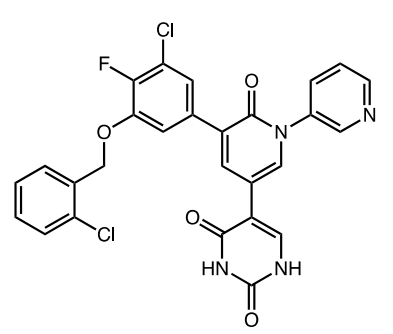

General Procedure D was employed using S7j to afford $\mathbf{1 8}(64.8 \mathrm{mg}$, $88 \%$ yield). ${ }^{1} \mathbf{H}$ NMR $\left(600 \mathrm{MHz}\right.$, DMSO- $\left.d_{6}\right) \delta 11.30(\mathrm{~s}, 1 \mathrm{H}), 11.23(\mathrm{~s}$, $1 \mathrm{H}), 8.69(\mathrm{~s}, 1 \mathrm{H}), 8.60(\mathrm{~s}, 1 \mathrm{H}), 8.02(\mathrm{~s}, 1 \mathrm{H}), 7.97(\mathrm{~d}, J=10.9 \mathrm{~Hz}, 2 \mathrm{H})$, $7.84(\mathrm{~d}, J=2.2 \mathrm{~Hz}, 1 \mathrm{H}), 7.64(\mathrm{~d}, J=6.9 \mathrm{~Hz}, 1 \mathrm{H}), 7.58(\mathrm{~d}, J=6.4 \mathrm{~Hz}$, $1 \mathrm{H}), 7.56-7.52(\mathrm{~m}, 2 \mathrm{H}), 7.50-7.46(\mathrm{~m}, 1 \mathrm{H}), 7.39-7.32(\mathrm{~m}, 2 \mathrm{H}), 5.23$ $(\mathrm{s}, 2 \mathrm{H}) .{ }^{13} \mathbf{C}$ NMR $\left(151 \mathrm{MHz}, \mathrm{DMSO}-d_{6}\right) \delta 163.0,159.0,150.7,148.9$, $147.3,146.9$ (d, $J=247.6 \mathrm{~Hz}), 139.6,139.1,137.3,136.2,134.6,133.1,132.8,131.2$ (d, $J=9.8$ $\mathrm{Hz}), 130.6,130.1,129.3,128.5$ (d, $J=11.7 \mathrm{~Hz}), 127.2,126.8,123.6,121.9,119.5$ (d, $J=14.8 \mathrm{~Hz})$, 114.5, 111.9, 107.2, 68.4. ${ }^{19} \mathbf{F}$ NMR (376 MHz, DMSO) $\delta-137.43(\mathrm{t}, J=6.7 \mathrm{~Hz})$. HRMS (ESI) $m / z:[\mathrm{M}+\mathrm{H}]^{+}$calcd for $\mathrm{C}_{27} \mathrm{H}_{18} \mathrm{Cl}_{2} \mathrm{FN}_{4} \mathrm{O}_{4}{ }^{+} 551.0684$, found 551.0688. 
5-(3-(3-Chloro-5-((2-chlorobenzyl)oxy)-4-fluorophenyl)-2-oxo-2H-[1,3'-bipyridin]-5-yl)-1methylpyrimidine-2,4(1H,3H)-dione (19)

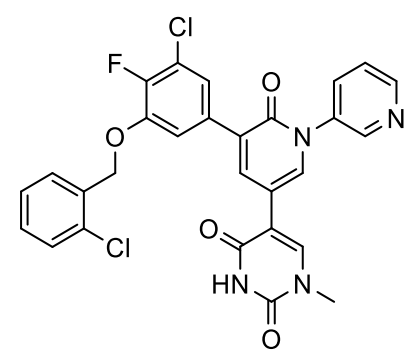

General Procedure E was employed using S7j to afford $19(23 \mathrm{mg}, 26 \%$ yield). ${ }^{1} \mathbf{H}$ NMR (600 MHz, DMSO- $\left.d_{6}\right) \delta 11.56(\mathrm{~s}, 1 \mathrm{H}), 8.73(\mathrm{~d}, J=2.5$ $\mathrm{Hz}, 1 \mathrm{H}), 8.65(\mathrm{dd}, J=4.8,1.4 \mathrm{~Hz}, 1 \mathrm{H}), 8.11(\mathrm{~s}, 1 \mathrm{H}), 8.08(\mathrm{~d}, J=2.5 \mathrm{~Hz}$, $1 \mathrm{H}), 8.04(\mathrm{~d}, J=2.5 \mathrm{~Hz}, 1 \mathrm{H}), 8.03-7.99(\mathrm{~m}, 1 \mathrm{H}), 7.67(\mathrm{dd}, J=7.4,1.8$ $\mathrm{Hz}, 1 \mathrm{H}), 7.60$ (ddd, $J=12.9,7.3,3.5 \mathrm{~Hz}, 2 \mathrm{H}), 7.55(\mathrm{dd}, J=6.1,1.9 \mathrm{~Hz}$, $1 \mathrm{H}), 7.50$ (dd, $J=7.4,1.8 \mathrm{~Hz}, 1 \mathrm{H}), 7.39$ (ddd, $J=6.3,3.8,1.9 \mathrm{~Hz}, 2 \mathrm{H})$, 5.26 (s, 2H), 3.29 (s, 3H). ${ }^{13}$ C NMR (151 MHz, DMSO- $\left.d_{6}\right) \delta 163.17$, 159.67, 150.99, 149.73, 148.49, 148.02, 147.01 (d, $J=10.4 \mathrm{~Hz}), 146.85,143.95,139.88,138.03$, $136.76,135.26,133.84,133.78(\mathrm{~d}, J=4.7 \mathrm{~Hz}), 133.53,131.22,130.85,129.98,127.94,127.76$, $124.37,122.56,120.28(\mathrm{~d}, J=15.0 \mathrm{~Hz}), 115.25,112.52,107.92,69.12,35.89 .{ }^{19} \mathbf{F}$ NMR $(376$ MHz, DMSO) $\delta-137.27\left(\mathrm{t}, J=6.9 \mathrm{~Hz}\right.$ ). HRMS (ESI) $m / z$ : $[\mathrm{M}+\mathrm{H}]^{+}$calcd for $\mathrm{C}_{28} \mathrm{H}_{20} \mathrm{Cl}_{2} \mathrm{FN}_{4} \mathrm{O}_{4}{ }^{+}$ 565.0840, found 565.0838

5-(3-(3-Chloro-5-((4-(trifluoromethyl)oxazol-5-yl)methoxy)phenyl)-2-oxo-2H-[1,3'bipyridin]-5-yl)-1-methylpyrimidine-2,4(1H,3H)-dione (20)

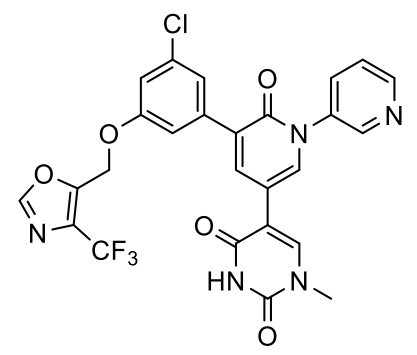

General Procedure E was employed using S7h to afford $20(8 \mathrm{mg}, 15 \%$ yield). ${ }^{1} \mathbf{H}$ NMR (400 MHz, DMSO-d $d_{6} \delta 11.54(\mathrm{~s}, 1 \mathrm{H}), 8.73(\mathrm{~s}, 2 \mathrm{H})$, $8.65(\mathrm{~d}, J=4.4 \mathrm{~Hz}, 1 \mathrm{H}), 8.13(\mathrm{~s}, 1 \mathrm{H}), 8.10(\mathrm{~d}, J=2.4 \mathrm{~Hz}, 1 \mathrm{H}), 8.04-$ $7.99(\mathrm{~m}, 2 \mathrm{H}), 7.60(\mathrm{dd}, J=8.1,4.8 \mathrm{~Hz}, 1 \mathrm{H}), 7.49$ (s, 1H), 7.37 (s, 1H), 7.18 (s, 1H), 5.36 (s, 2H), 3.28 (s, 3H). ${ }^{13} \mathrm{C}$ NMR (101 MHz, DMSO$\left.d_{6}\right) \delta 163.16,159.59,158.34,154.22,150.96,149.54,147.87,143.92$, $139.81,139.63,138.11,136.85,135.47,133.80,128.13,124.45,122.22$, 114.88, 114.34, 112.44, 107.78, 59.55, 35.86. ${ }^{19}$ F NMR (376 MHz, DMSO) $\delta-61.41$. HRMS (ESI) $m / z:[\mathrm{M}+\mathrm{H}]^{+}$calcd for $\mathrm{C}_{26} \mathrm{H}_{18} \mathrm{ClF}_{3} \mathrm{~N}_{5} \mathrm{O}_{5}{ }^{+}$572.0943, found 572.0942

\section{5-(3-(3-Chloro-5-((4-(trifluoromethyl)thiazol-5-yl)methoxy)phenyl)-2-oxo-2H-[1,3'-} bipyridin]-5-yl)-1-methylpyrimidine-2,4(1H,3H)-dione (21)

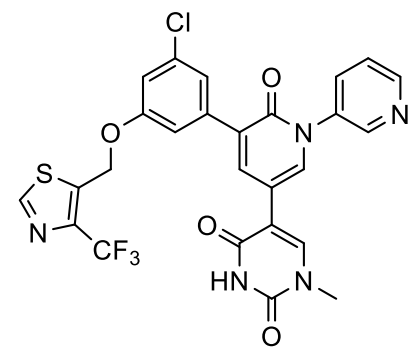

General Procedure E was employed using S7i to afford 21 (12 mg, 19\% yield). ${ }^{1} \mathbf{H}$ NMR (600 MHz, DMSO- $\left.d_{6}\right) \delta 11.55$ (s, 1H), $9.23(\mathrm{~s}, 1 \mathrm{H})$, $8.73(\mathrm{~s}, 1 \mathrm{H}), 8.65(\mathrm{~s}, 1 \mathrm{H}), 8.12(\mathrm{~s}, 1 \mathrm{H}), 8.09(\mathrm{~d}, J=2.0 \mathrm{~Hz}, 1 \mathrm{H}), 8.02$ $(\mathrm{d}, J=2.2 \mathrm{~Hz}, 1 \mathrm{H}), 8.00(\mathrm{~d}, J=8.2 \mathrm{~Hz}, 1 \mathrm{H}), 7.59(\mathrm{dd}, J=8.0,4.8 \mathrm{~Hz}$, 1H), 7.47 (s, 1H), 7.39 (s, 1H), 7.18 (s, 1H), 5.55 (s, 2H), 3.29 (s, 3H). ${ }^{13}$ C NMR (151 MHz, DMSO-d $\left.d_{6}\right) \delta 163.17,159.61,158.28,156.74$, $150.97,149.71,148.01,143.92,139.83,139.64,138.50,138.48,138.09$, $136.86,135.27,133.85,128.13,124.39,122.43,122.16,120.63,115.01,114.40,112.45,107.81$, 61.88, 35.86. ${ }^{19}$ F NMR (376 MHz, DMSO) $\delta$-59.64. HRMS (ESI) $m / z:[\mathrm{M}+\mathrm{H}]^{+}$calcd for $\mathrm{C}_{26} \mathrm{H}_{18} \mathrm{ClF}_{3} \mathrm{~N}_{5} \mathrm{O}_{4} \mathrm{~S}^{+}$588.0715, found 588.0713 


\section{Assessment of Antiviral Activity Against SARS-CoV-2 and Cellular Cytotoxicity}

\section{i. Cells}

Vero E6 were cultured in Dulbecco's Modified Eagle Medium (DMEM) with 10\% heatinactivated fetal bovine serum (FBS), and 1\% Penicillin/Streptomycin unless otherwise indicated. For Vero E6, $5 \mu \mathrm{g} / \mathrm{mL}$ of puromycin (GIBCO) and $5 \mu \mathrm{g} / \mathrm{mL}$ blasticidin (GIBCO) were added as appropriate. Normal human bronchial epithelial cells (16HBE140-) were a kind gift of Dr. Marie Egan, Yale University School of Medicine. Cells were grown in T75 flasks coated with fibronectin, $\mathrm{BSA}$, and Collagen $\mathrm{ECM}$ at $37^{\circ} \mathrm{C}$ in a humidified incubator with $5 \% \mathrm{CO}_{2}$. Cells were grown in minimum essential media containing 10\% FBS and 1\% penicillin /streptomycin (Gibco). All cell lines used were tested for mycoplasma contamination before use.

\section{ii. Viral stocks}

To generate viral stocks, Vero E6 cells were inoculated with the SARS-CoV-2 isolate USAWA1/2020 (BEI Resources \#NR-52281) at an MOI of 0.01 for three days to generate a P1 stock. The P1 stock was used to inoculate Vero E6 cells at an multiplicity of infection (MOI) of 0.01 for three days at approximately 50\% cytopathic effects. Virus titer was determined by plaque assay using Vero E6 cells.

\section{iii. Viral growth and plaque assay}

For virus growth experiments, Vero E6 cells were seeded at $4 \times 10^{5}$ cells/well in 12-well plates and infected for 1 hour with the SARS-CoV-2 isolate USA-WA1/2020 at an MOI of 0.01. The cells were washed twice to remove residual unattached virus. Serial dilutions of each compound (0.1\% DMSO in 2\% FBS in DMEM media) were added to the cells and incubated at $37^{\circ} \mathrm{C}$ ( 2 dpi). After $2 \mathrm{dpi}$, the supernatant containing virus was cleared from cell debris at 1000 rpm for $10 \mathrm{~min}$ and frozen until analysis via plaque assay.

For the plaque assay, Vero E6 cells were seeded at $7.5 \times 10^{5}$ cells/well in 6-well plates. The following day, the media was removed and replaced with $100 \mu \mathrm{L}$ of 10 -fold serial dilutions of previously frozen viral supernatant. Plates were incubated at $37^{\circ} \mathrm{C}$ for 1 hour with gentle rocking. Subsequently, overlay media (DMEM, 2\% FBS, 0.6\% Avicel RC-581) was added to each well. At 2 dpi for SARS-CoV-2 plates were fixed with $10 \%$ formaldehyde for 30 min, stained with crystal violet solution ( $0.5 \%$ crystal violet in $20 \%$ ethanol) for $30 \mathrm{~min}$, and then rinsed with deionized water to visualize plaques. 


\section{iv. Antiviral Assay and Cellular Cytotoxicity using MTT and AlamarBlue}

The antiviral activity of compounds was examined by evaluating the cytopathic effect in Vero E6 cells grown at $37^{\circ} \mathrm{C}$ in a $5 \% \mathrm{CO}_{2}$ atmosphere for $72 \mathrm{~h}$ using 96 multi-well plates $(50,000$ cells/ well) using 3-(4,5-dimethyl-2- thiazolyl)-2,5-diphenyl-2H-tetrazolium bromide (MTT; Sigma- Aldrich) method according to the manufacturer's instructions. Cells were challenged with SARS-CoV-2 at a multiplicity of infection (MOI) of 0.01 . The virus was added together with the compound(s) under investigation and incubated in DMEM supplemented with $2 \%$ FBS and using $0.1 \%$ DMSO with no inhibitor as a control. To assess in vitro antiviral activity, serial dilutions of compounds in $(0.1 \%$ DMSO in $2 \%$ FBS in DMEM media) were made in a concentration range of $0.1 \mu \mathrm{M}$ to $25 \mu \mathrm{M}$. Optical densities were measured at 560/620 nm with a Spectramax Plate Reader. Three independent experiments with triplicate measurements were performed. Data were analyzed by a four-parameter curve-fitting from a dose-response curve using GraphPad Prism (version 8.00) to calculate the $\mathrm{EC}_{50}$ (concentration of the compound that inhibited $50 \%$ of the infection) based on the MTT method. Concurrently in this experiment, general cellular cytotoxicity $\left(\mathrm{CC}_{50}\right)$ in the absence of virus was determined. The MTT assay was also used to assess compound cytotoxicity in human normal bronchial epithelial cells (NHBE). We found that there appeared to be some type of dye interference with the MTT assay when the uracil compounds were used therefore we employed alamarBlue which used a resazurin based dye instead. The almarBlue protocol to determine $\mathrm{EC}_{50}$ and $\mathrm{CC}_{50}$, is similar to that for MTT. Briefly, $1 \times 10^{5} / \mathrm{ml}$ Vero E6 cells in a final volume of $110 \mu \mathrm{L}$ were plated in a 96-well plate containing $10 \mu \mathrm{l}$ of two-fold drug dilutions. Where appropriate SARS-CoV-2 virus was added at MOI of 0.05 . After $72 \mathrm{~h}$ incubation in a $37^{0} \mathrm{C} 5 \% \mathrm{CO}_{2}$ incubator, $11 \mu \mathrm{l}$ of AlamarBlueHS (Catalog Numbers DAL1025 and DAL1100) was added to each well according to the manufacturer's instructions (ThermoFisher). To calculate the cell viability, cells were incubated for additional $3 \mathrm{~h}$ at $37^{\circ} \mathrm{C} 5 \% \mathrm{CO} 2$ incubator followed by an endpoint fluorescence intensity reading at $560 \mathrm{nM}$ excitation/590 nM emission. Data were processed as described above.

\section{v. Quantification and statistical analysis}

Statistical significance was determined as $\mathrm{p}<0.05$ using GraphPad Prism 8 unless otherwise indicated. Experiments were analyzed by unpaired two-tailed t tests, Mann-Whitney test, or ANOVA, as indicated.

\section{vi. Replicon Assay to assess inhibition of viral replication}

A SARS-CoV-2 replicon was generated by replacing the Spike gene with a Nano luciferase (Nluc) gene within a full-length infectious cDNA clone of the viral genome stably maintained within the yeast artificial chromosome (YAC) pCC1BAC-HIS3/SARS-CoV-2 (PMID: 32365353). Briefly, the Nluc gene was amplified to add flanking SARS-CoV-2 sequences and remove an 
internal EagI site in two steps. First, the 5' end of the Nluc gene was amplified by using Q5 DNA polymerase (New England Biolabs) with primers YO-3778 (5'-GAG TTG TTA TTT CTA GTG ATG TTC TTG TTA ACA ACT AAA CGA ACA ATG GTC TTC ACA CTC GAA GAT TT-3') and YO-4096 (5'-GCC TTC ATA GGG GCG TCC GAA ATA GTC GAT-3'); the 3' end of the Nluc gene was amplified by using Q5 DNA polymerase with primers YO-4101 (5'-CGA CTA TTT CGG ACG CCC CTA TGA AGG CAT CGC CGT GTT-3') and YO-3779 (5'-CAG TTC CAA TTG TGA AGA TTC TCA TAA ACA AAT CCA TAA GTT CGT TTA CGC CAG AAT GCG TTC GCA CA-3'). The full-length Nluc gene was then amplified by using Q5 DNA polymerase with primers YO-3778 and YO-3779 and inserted into BamHI-linearized pCC1BAC-HIS3/SARS-CoV2 by cotransfection into yeast VL6-48N (PMID: 9207100) and selection of homologous recombinants on histidine-deficient media. YACs were recovered from liquid cultures by treatment with zymolase (Zymo Research) and ZymoPURE plasmid midiprep kits (Zymo Research), then transformed into Epi300 bacterial cells (Lucigen). Chloramphenicol-resistant colonies were picked and grown in liquid media with CopyControl induction solution, then used to prepare amplified YAC by using the ZymoPURE plasmid midiprep kit. The replicon-bearing YAC was sequence verified by whole plasmid sequencing (Massachusetts General Hospital Genome DNA Core) and linearized by overnight digestion with EagI. Linearized transcription templates were purified by treatment at $55^{\circ} \mathrm{C}$ with $0.5 \%$ (W/V) SDS and 3 units proteinase $\mathrm{K}$ followed by two rounds of phenol/chloroform extraction and ethanol precipitation. Replicon RNAs were transcribed from purified transcription templates with the T7 Ribomax kit (Promega) and antireverse cap analog (New England Biolabs). RNAs were purified by treatment with RQ1 DNase (Promega) and RNA Clean \& Concentrator-25 kit (Zymo), eluted into $2 \mathrm{mM}$ sodium citrate (pH 6.4), aliquoted in $1 \mu \mathrm{g}$ portions, and stored frozen at $-80^{\circ} \mathrm{C}$. RNAs were transfected into BHK cells engineered to express a human codon-optimized SARS-CoV-2 nucleoprotein gene by electroporation (PMID: 9371625). Cells were then seeded in multiple replicates on 96-well plates containing serial dilutions of the test compounds; remdesivir was used as a positive control. The following day, Nluc activity was measured by using NanoGlo reagents (Promega) with a CentroXS3 LB 960 microplate luminometer (Berthold).

\section{Crystallographic Data and Enzyme Kinetics}

\section{i. Recombinant SARS-CoV-2 $\mathrm{M}^{\text {Pro }}$ Expression}

Recombinant SARS-CoV-2 $\mathrm{M}^{\mathrm{Pro}}$ with native $\mathrm{N}$ - and C-termini was expressed and purified as previously described ${ }^{2,3}$. Protein was buffer exchanged ( $20 \mathrm{mM}$ Tris, $150 \mathrm{mM} \mathrm{NaCl}, 1 \mathrm{mM}$ EDTA, $1 \mathrm{mM}$ DTT, $\mathrm{pH} 7.8$ ) and stored at $-80^{\circ} \mathrm{C}$ at $20 \mathrm{mg} / \mathrm{mL}$. Protein samples were thawed on ice and incubated at $37^{\circ} \mathrm{C}$ with $2 \mathrm{mM}$ compound in DMSO for 30 minutes. Samples were then centrifuged at $10,000 \mathrm{xg}$. The supernatant was used to set up crystallization screens with the commercially available PEGRx1 and PEGRx2 screens (Hampton Research). Crystal screens were 
set up manually with $2 \mu \mathrm{L}$ drops with a 1:1 protein/reservoir solution ratio. Wells were set up with $80 \mu \mathrm{L}$ of reservoir solution via the sitting-drop vapor-diffusion method at $18^{\circ} \mathrm{C}$. Plate-like or small, three-dimensional crystals appeared overnight. Crystals were harvested, cryo-protected with 15\% glycerol and flash frozen in liquid nitrogen.

\section{ii. Structural determination of MPro bound to compound 13}

X-ray data was collected at the National Synchrotron Light Source II (NSLS-II) and Advanced Photon Source (APS) on beamlines AMX and 24-ID-E/24-ID-C, respectively. Datasets were indexed using XDS ${ }^{4}$. Molecular replacement was done by using PHASER ${ }^{5}$. 6Y2F was used as the search model. COOT was used for modeling building, and Phenix Refine was used for successive rounds of refinement ${ }^{6,7}$. Data processing statistics are in Table S1. All software was compiled by SBGrid ${ }^{8}$.

\section{iii. Enzyme Kinetics}

Purified protein is diluted in reaction buffer to $100 \mathrm{nM}$ in an opaque 96-well plate. The protein is incubated with or without compound in DMSO at different concentrations for 15 minutes while shaking. The reaction is initiated by the addition of a $50 \mu \mathrm{M}$ FRET substrate (DabcylKTSAVLQ $\downarrow$ SGFRKM-E(Edans-NH2); GL Biochem) in reaction buffer. Cleavage of the substrate generates a free Edans group. Fluorescence is monitored at an excitation wavelength of 360nm and an emission wavelength of 460nm. Baseline subtraction was performed to control for intrinsic fluorescence of each compound. All experiments were performed in triplicate.

\section{iv. Quantification and Statistical Analysis}

Kinetic analyses were performed in GraphPad Prism 8. Data was plotted and initial rate was calculated using the slope of the kinetic curve via linear regression analysis. The initial velocity was calculated from the reaction of MPro and substrate without inhibitor. $\mathrm{V}_{\mathrm{i}} / \mathrm{V}_{0}$ was plotted against the $\log$ (inhibitor concentration) and $\mathrm{IC}_{50}$ curves were generated for each replicate using nonlinear regression. Triplicate $\mathrm{IC}_{50}$ values were averaged.

Table S1. Diffraction data and refinement statistics.

\begin{tabular}{|c|c|}
\hline Complex & Mpro:Compound 13 \\
\hline PDB Code & 7N44 \\
\hline Data Collection & \\
\hline X-Ray Source & APS 24ID-E \\
\hline Wavelength, $\AA$ & 0.97918 \\
\hline Space Group & $\mathrm{C} 121$ \\
\hline Cell Dimensions & \\
\hline
\end{tabular}




\begin{tabular}{|c|c|}
\hline $\mathrm{a}, \mathrm{b}, \mathrm{c}(\AA)$ & $116.895,53.309,44.911$ \\
\hline$\alpha, \beta, \gamma\left({ }^{\circ}\right)$ & $90,101.886,90$ \\
\hline Resolution $(\AA)$ & $57.194-1.941(2.06-1.941)$ \\
\hline$R_{\text {merge }}$ & $96.73(90.06)$ \\
\hline$I / \sigma I$ & $12.79(2.69)$ \\
\hline Completeness (\%) & $96.73(90.06)$ \\
\hline Redundancy & 3.55536482953 \\
\hline \multicolumn{2}{|l|}{ Refinement } \\
\hline Resolution $(\AA)$ & $57.19-1.94(2.06-1.941)$ \\
\hline No. reflections & 134,631 \\
\hline$R_{\text {work }} / R_{\text {free }}$ & $0.1864 / 0.2185$ \\
\hline \multicolumn{2}{|l|}{ No. atoms } \\
\hline Protein & 2228 \\
\hline Inhibitor & 53 \\
\hline Water & 149 \\
\hline \multicolumn{2}{|l|}{$B$-factors } \\
\hline Protein & 39.52 \\
\hline Inhibitor & 38.59 \\
\hline Water & 45.77 \\
\hline \multicolumn{2}{|l|}{ R.m.s deviations } \\
\hline Bond lengths $(\AA)$ & 0.007 \\
\hline Bond angles $\left({ }^{\circ}\right)$ & 0.85 \\
\hline \multicolumn{2}{|l|}{ Ramachandran } \\
\hline Favored (\%) & 97.95 \\
\hline Allowed (\%) & 2.05 \\
\hline Outliers (\%) & 0.00 \\
\hline
\end{tabular}

\section{Solubility Assay}

The thermodynamic solubilities of compounds 3-4, 9-11, 16-21 and piroxicam as control were measured following the procedure described before ${ }^{9,10}$. The original method was adapted to a 96-well plate setting to facilitate fast absorbance readouts through a microplate reader.

\section{Materials and methods}

1. Samples and Chemicals:

All the tested compounds were synthesized in-house; piroxicam ( $\geq 98 \%$ (TLC)) was purchased from Sigma Aldrich.

2. Buffer solutions used for the solubility experiments: 
Britton-Robinson (BR) buffer $\mathrm{pH} 6.5$ was used for all the tested compounds and BR buffer $\mathrm{pH} 3.7$ for the control compound. BR buffers comprise acetic, phosphoric, and boric acid, each at $0.04 \mathrm{M}$. The buffers were prepared using a $0.2 \mathrm{M} \mathrm{NaOH}$ solution to adjust the mixture to the desired $\mathrm{pH}$.

\section{Apparatus:}

The $\mathrm{pH}$ of the buffer solutions was measured using Orion Star A111 $\mathrm{pH}$ meter and Orion 8102BNUWP Ross Ultra, Glass body, combination pH electrode. A Corning PC 620 magnetic stirrer was used to mix the two phases. Samples were filtered using an Agilent Syringe filter $(0.45$ $\mu \mathrm{m}$ pore size, $25 \mathrm{~mm}$ ). All the samples were measured in Greiner Bio-One UV-Star ${ }^{\mathrm{TM}}$ 96-Well UV Spectroscopy Microplates. The absorbance of the samples was measured using TECAN Spark microplate reader.

4. Experimental Details and Setup:

All the solubility experiments were conducted at $21-22^{\circ} \mathrm{C}$. The equilibrium solubility of the un-ionized form of the samples was determined by the shake-flask method.

The experiment was comprised of two parts: a) calibration and b) measurement. The calibration and measurement (after $48 \mathrm{~h}$ of stirring) were performed on the same day. A control sample was measured for every batch of tested compounds.

\section{A. Calibration.}

For the quantitative determination of the aqueous solubility, a calibration curve had to be constructed for each compound: a stock solution of $1 \mathrm{mg} / \mathrm{mL}$ in DMSO was prepared and was then mixed with BR buffer (1:1 DMSO: BR buffer) in order to obtain 10 serial dilutions from 500 $\mu \mathrm{g} / \mathrm{mL}$ to $0.98 \mu \mathrm{g} / \mathrm{mL} .2$ independent series of serial dilutions were prepared, and each concentration was measured in duplicate $(2 \times$ quadruplicate measurements) for each series in a 96well plate $(200 \mu \mathrm{L}$ per well). A mixture of BR buffer and DMSO (1:1 ratio) was used as blank, BR buffer $\mathrm{pH} 6.5$ was used for the tested compounds and BR buffer $\mathrm{pH} 3.7$ for the control.

Once the plate was prepared, an absorbance scan was performed, covering the full range of wavelengths from 200-800 $\mathrm{nm}$. The results were processed via excel and Prism 8.0.0, to allow averaging, blank subtraction and manual baseline correction were performed $(\lambda=800 \mathrm{~nm}$ was considered as the baseline). The wavelength of maximum absorption for each compound, $\lambda \max$, was then determined from its absorption spectrum. Subsequently, the data of the absorbance at different concentrations, at $\lambda \max$, were fit in a model using linear regression. Outliers were eliminated to allow for the best fit, resulting in the equation to describe the relation between absorbance (A) and concentration (C), according to Lambert-Beer law, A = ebC.

\section{B. Measurement.}

1-2 $\mathrm{mg}$ of each tested compound were suspended in BR buffer $\mathrm{pH} 6.5(1 \mathrm{mg} / \mathrm{mL})$ in a 1dram glass vial, equipped with a stir bar. The mixture containing solid excess of the tested compound was stirred for $48 \mathrm{~h}$ before separating saturated solution and precipitate by filtration. 
After filtration, the saturated solution was divided in different vials, and each one was mixed with DMSO (1:1 ratio). The samples were used to fill the wells of a 96-well plate, with $200 \mu \mathrm{L}$ per well, such that two or three measurements (in triplicate or quadruplicate) could be carried out in parallel. Again, a mixture of BR buffer and DMSO (1:1 ratio) was used as blank (2x quadruplicate measurements). The concentration of the measured samples was determined using their absorption at $\lambda \max$, and the equation that was determined for each compound previously (as described in part A.). The measured values were corrected for a dilution factor of 2.

\section{PAMPA Assay}

PAMPA experiments ${ }^{11,12}$ were performed in a 96-well $0.45 \mathrm{~mm}$ filter plate containing hydrophobic PVDF membranes (Millipore). The artificial membrane was formed by adding $5 \mathrm{~mL}$ of a solution containing 4\% lecithin (Sigma P5638) in dodecane to each filter. $200 \mathrm{~mL}$ of donor solutions containing saturated or up to $500 \mathrm{mM}$ concentrations of compound in PBS pH 7.4 and $5 \%$ DMSO were added to the top donor wells. $300 \mathrm{ml}$ of PBS pH7.4 buffer were added to the receiving wells of the acceptor plate. After the stacked donor and acceptor plates were incubated at room temperature for 18 hours, the concentrations of compound in the acceptor solutions were measured by a multi-wavelength UV plate reader. Experiments were performed in duplicate for each compound. An equilibrium standard was made for each compound containing $40 \%$ concentration of the donor solution to represent the concentration of the acceptor solution if full permeability was achieved. The apparent permeability of each compound was calculated by the following equation:

$$
\mathrm{P}_{\mathrm{PAMPA}}=\left(\left(\mathrm{V}_{\mathrm{D}} \times \mathrm{V}_{\mathrm{A}}\right) /\left(\left(\mathrm{V}_{\mathrm{D}}+\mathrm{V}_{\mathrm{A}}\right) \times \mathrm{S} \times \mathrm{t}\right)\right) \times\left(-\ln \left(1-\left(\mathrm{OD}_{\mathrm{A}} / \mathrm{OD}_{\mathrm{E}}\right)\right)\right) \mathrm{cm} / \mathrm{s}
$$

Where $V_{D}$ and $V_{A}$ are the volumes of the donor and acceptor solutions, $S$ is the membrane surface area, $t$ is the time of incubation, and $\mathrm{OD}_{\mathrm{A}}$ and $\mathrm{OD}_{\mathrm{E}}$ are the absorbances of the acceptor solution and equilibrium standards, respectively.

\section{Computational Details}

The principal computations were conjugate-gradient energy minimizations and Monte Carlo/FEP (MC/FEP) calculations, which yield relative free energies of binding. The necessary structures for complexes were built with the BOMB program ${ }^{13}$ starting with the $5 \mathrm{R} 82$ crystal structure for the protein. The FEP calculations were carried out using standard protocols with the MCPRO program ${ }^{14}$ and the OPLS-AA/M and OPLS/CM1A force fields for the protein and ligands, respectively. ${ }^{15-17}$ The configurational sampling for the systems was performed at $25{ }^{\circ} \mathrm{C}$ including the 242 protein residues nearest to the active site. The unbound ligands and complexes were solvated in TIP4P water ${ }^{18}$ spheres ("caps") with a 25 - $\AA$ radius; after removal of water molecules in too close contact with solute atoms, ca. 2000 and 1250 water molecules remained for 
the unbound and bound MC simulations. Short conjugate-gradient minimizations were carried out on the initial structures for all complexes to relieve any unfavorable contacts. Coordinates for the free ligands were obtained by extraction from the complexes. The FEP calculations utilized 11 windows of simple overlap sampling ${ }^{19}$ and 10 - $\AA$ residue-based cutoffs. Each window covered 1015 million (M) configurations of equilibration and 20-50 M configurations of averaging at $25^{\circ} \mathrm{C}$. The ligand and side chains with any atom within ca. $10 \AA$ of the ligand were fully flexible, while the protein backbone was kept fixed during the MC runs. 


\section{NMR Spectral Data}

8, ${ }^{1} \mathrm{H}$ NMR $\left(600 \mathrm{MHz}\right.$, DMSO- $\left.d_{6}\right)$

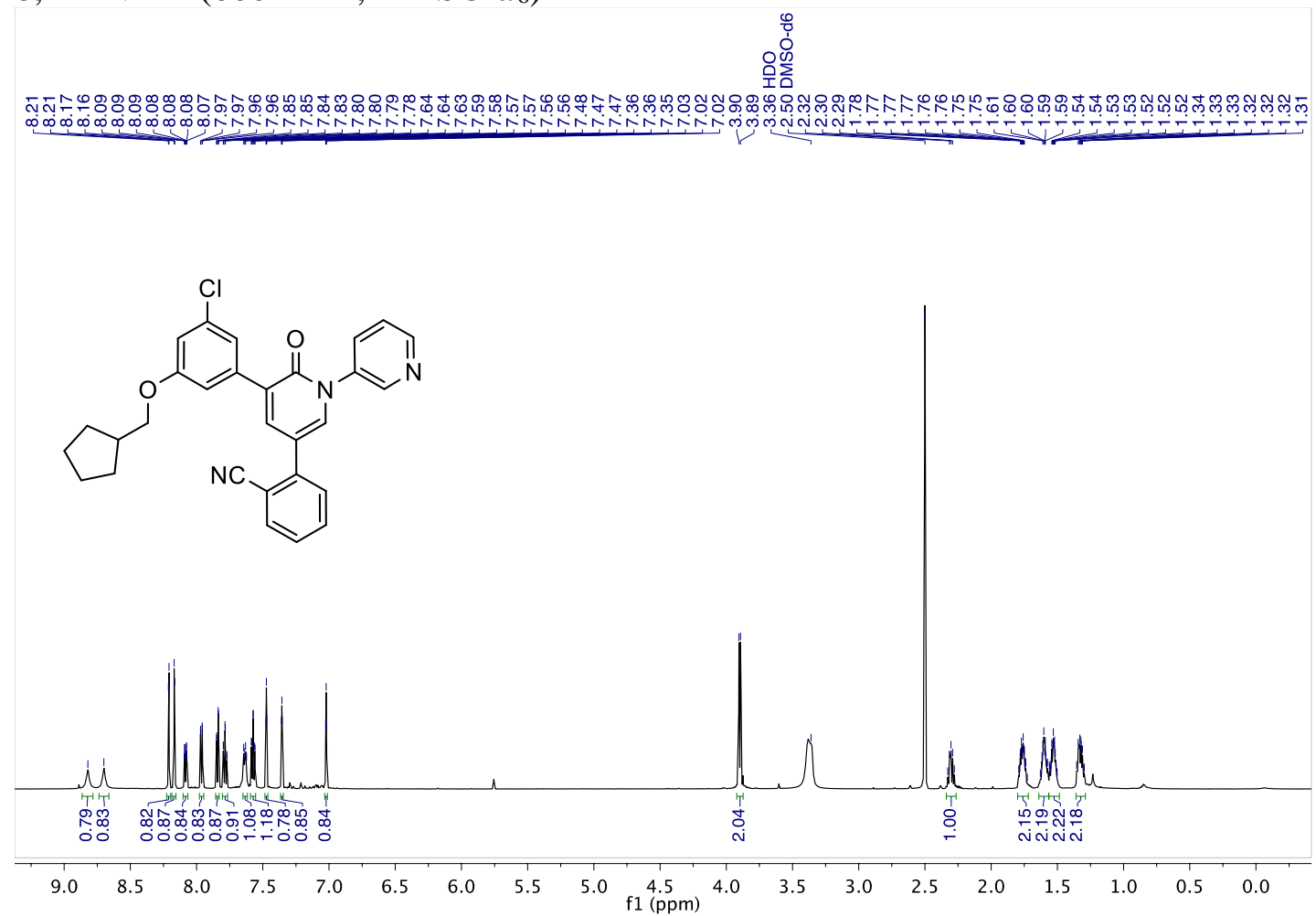

8, ${ }^{13} \mathrm{C}$ NMR $\left(151 \mathrm{MHz}, \mathrm{CDCl}_{3}\right)$

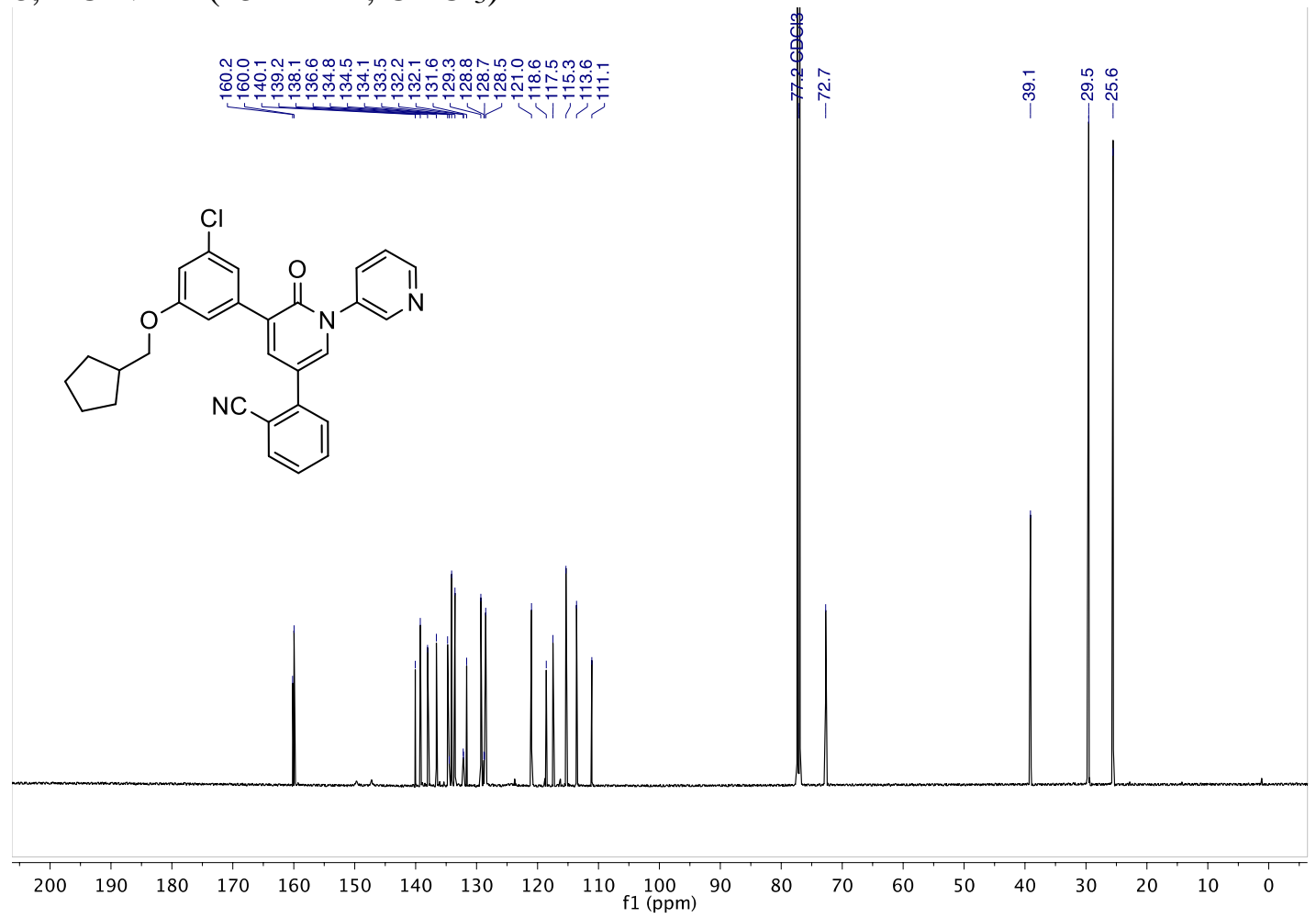


9, ${ }^{1} \mathrm{H}$ NMR $\left(400 \mathrm{MHz}, \mathrm{CDCl}_{3}\right)$

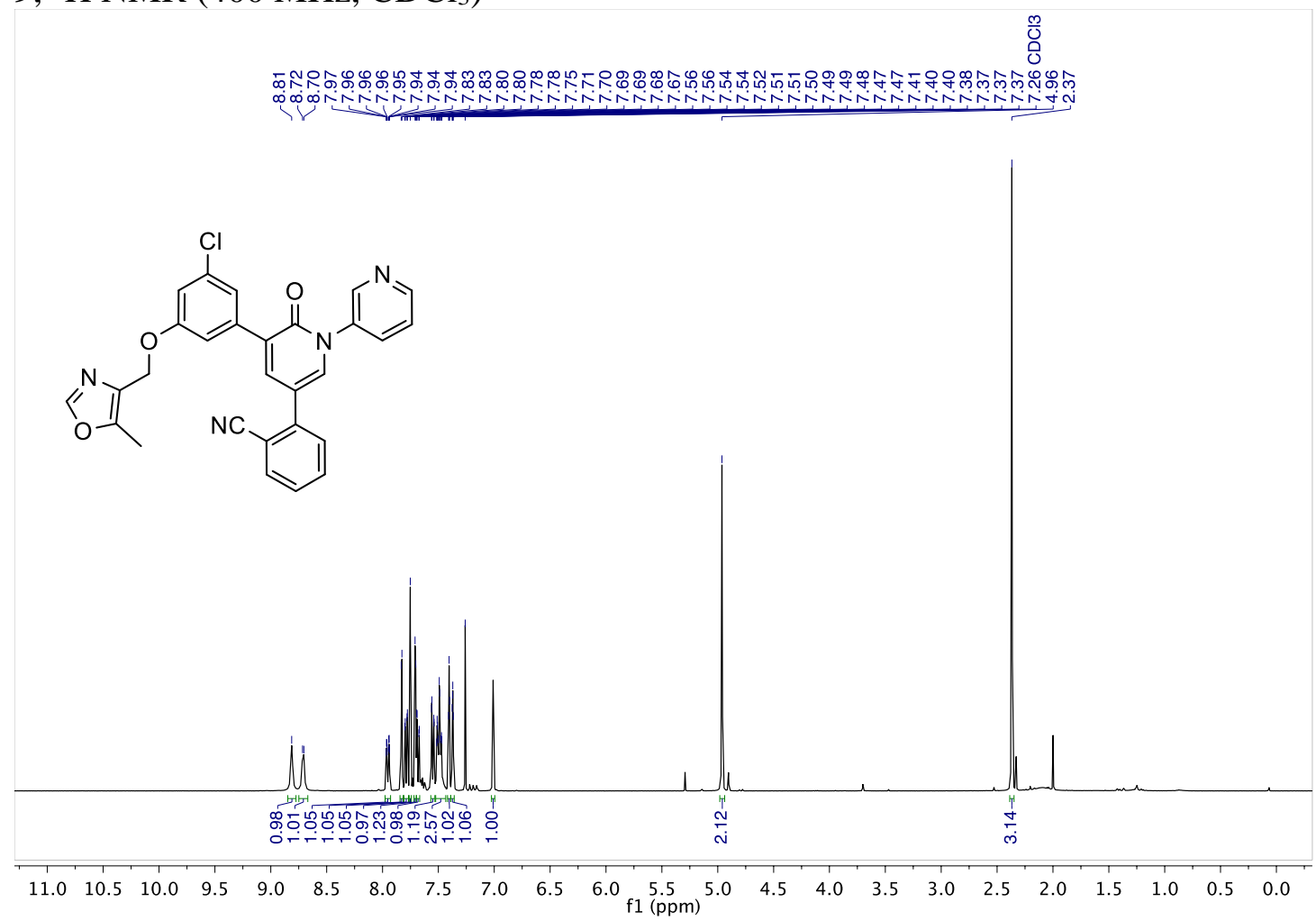

9, ${ }^{13} \mathrm{C}$ NMR $\left(151 \mathrm{MHz}, \mathrm{CDCl}_{3}\right)$

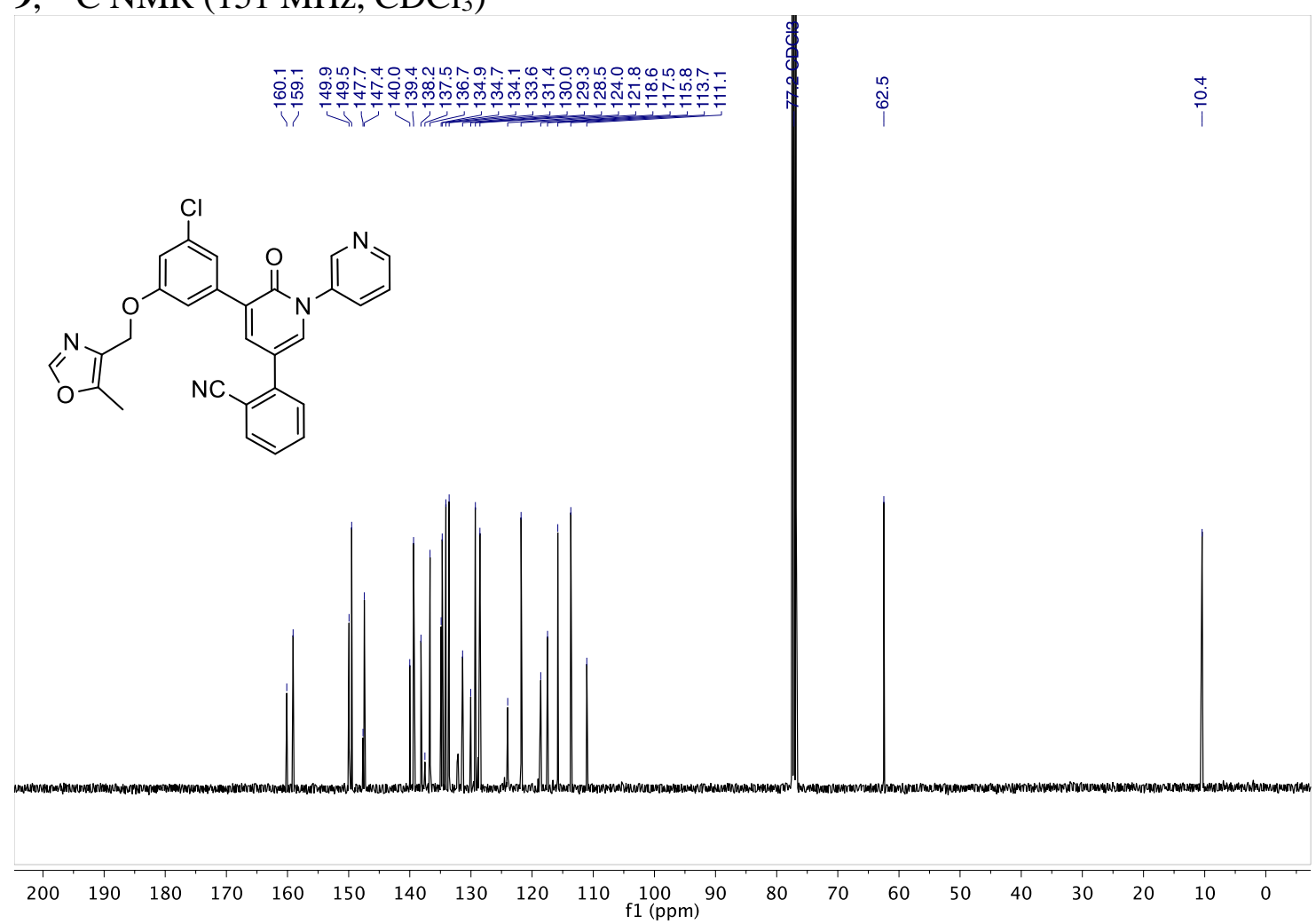


10, ${ }^{1} \mathrm{H}$ NMR (400 MHz, DMSO- $\left.d_{6}\right)$

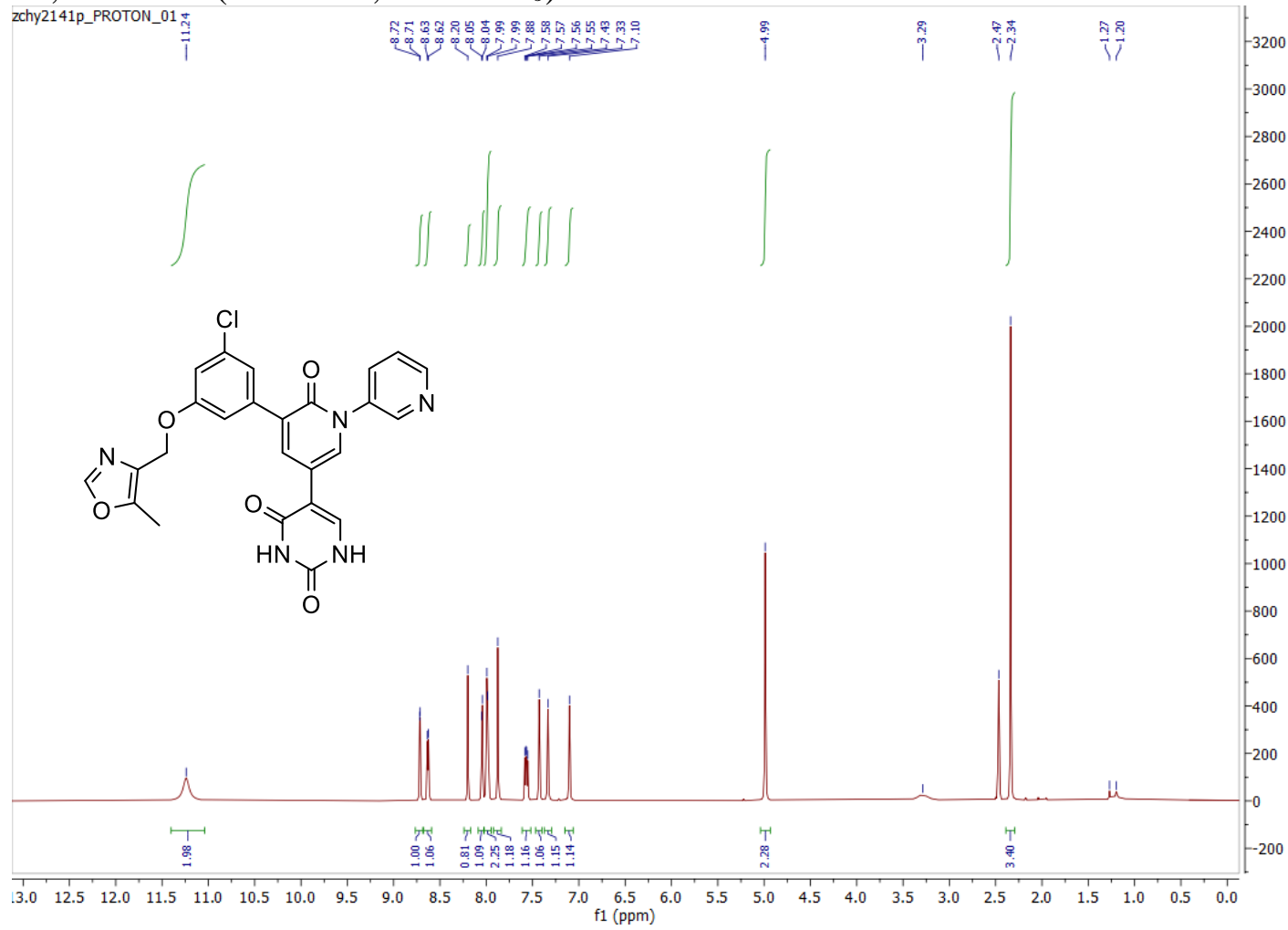

10, ${ }^{13} \mathrm{C}$ NMR (101 MHz, DMSO- $\left.d_{6}\right)$

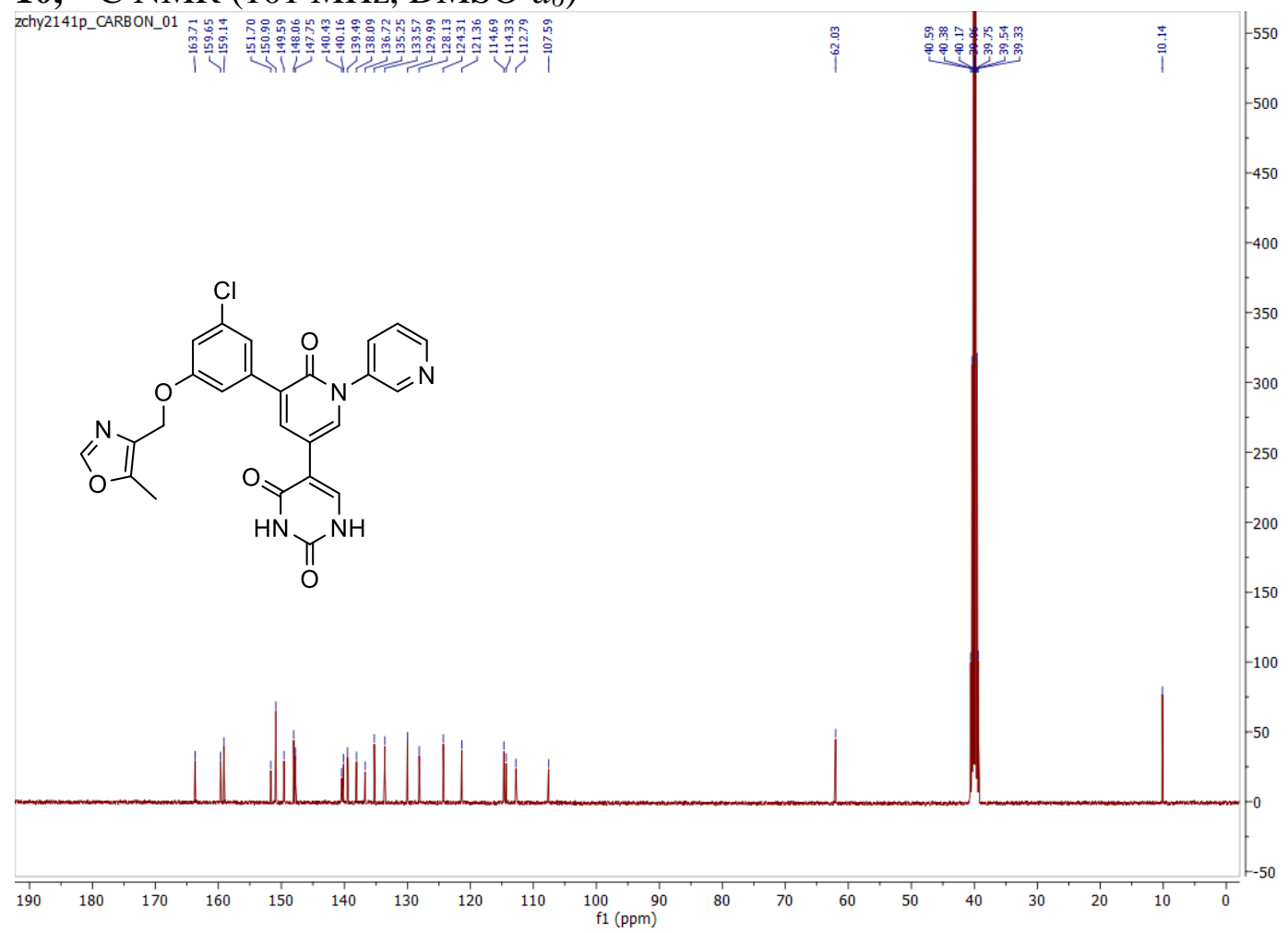


11, ${ }^{1} \mathrm{H}$ NMR (400 MHz, DMSO- $d_{6}$ )

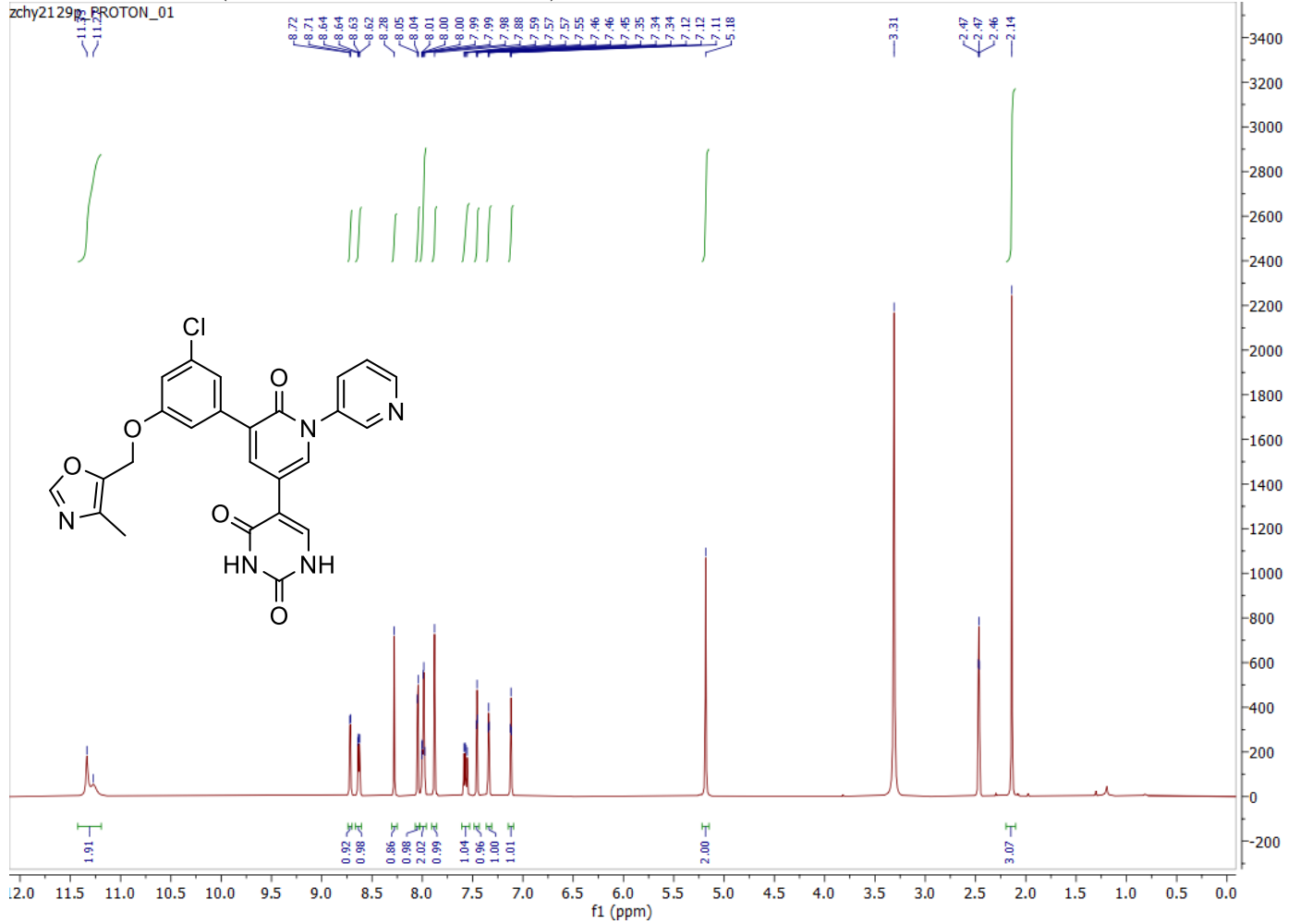

11, ${ }^{13} \mathrm{C}$ NMR (101 MHz, DMSO- $\left.d_{6}\right)$

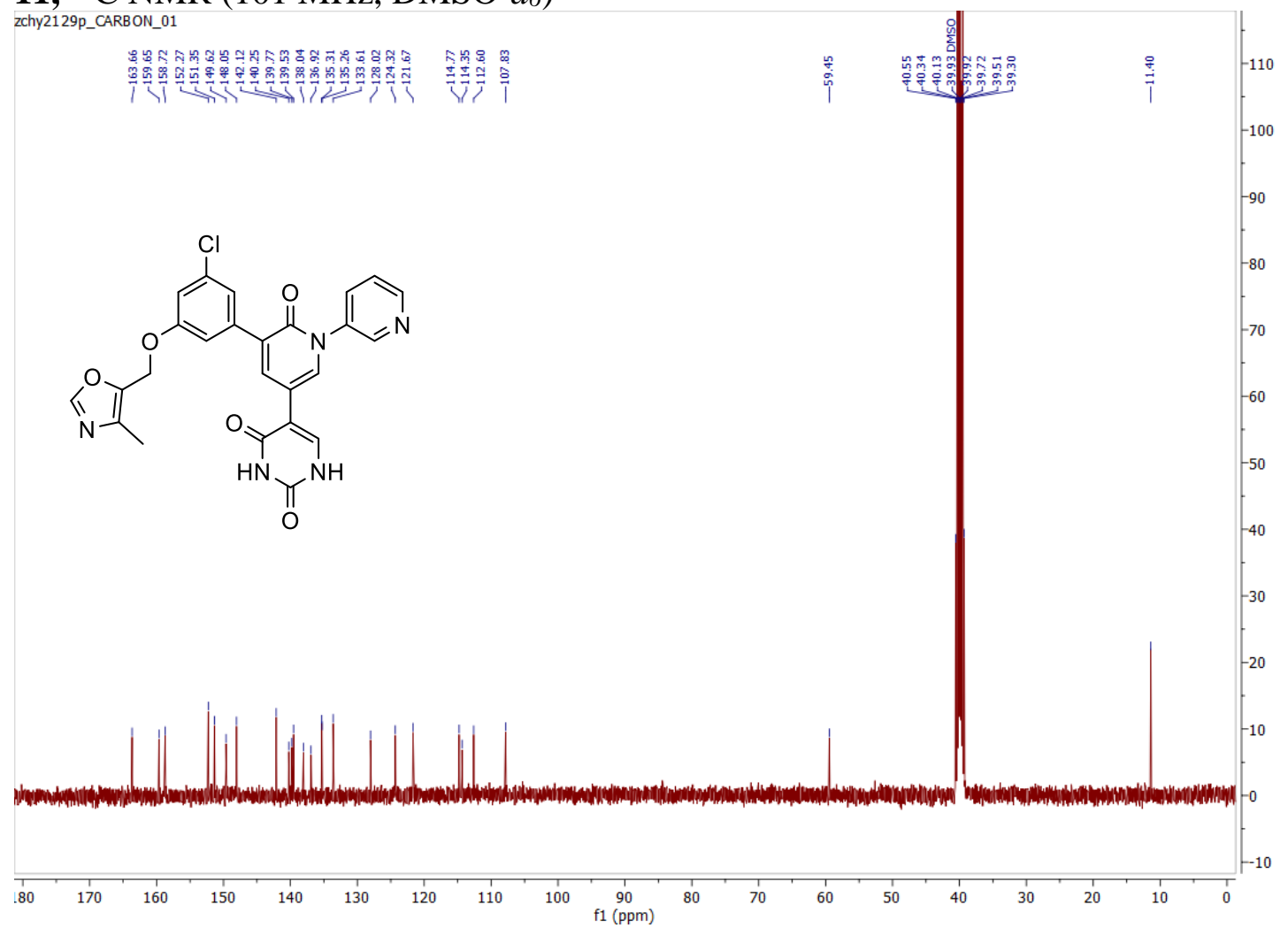


12, ${ }^{1} \mathrm{H}$ NMR (600 MHz, DMSO- $\left.d_{6}\right)$

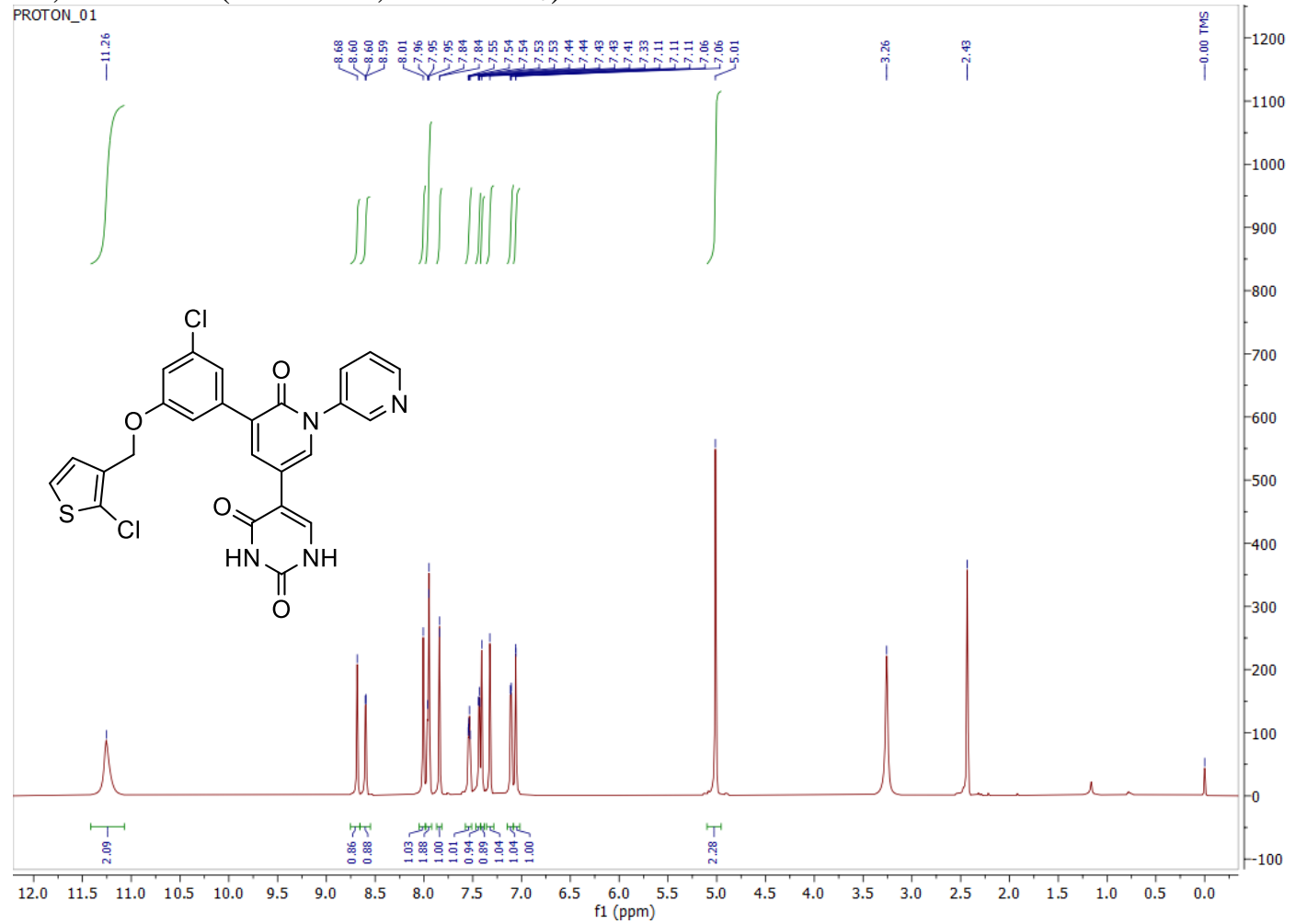

12, ${ }^{13} \mathrm{C}$ NMR (151 MHz, DMSO- $d_{6}$ )

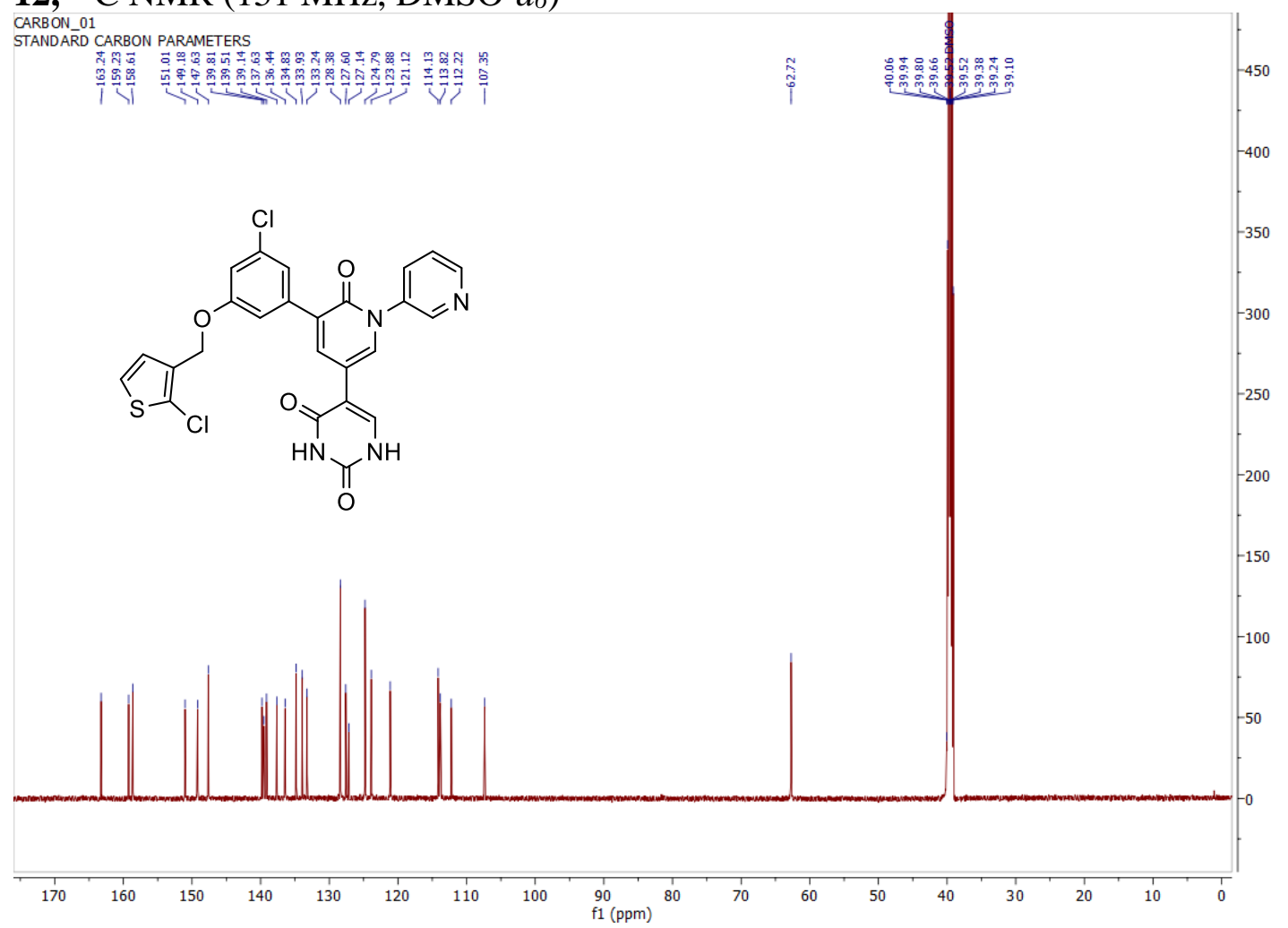


13, ${ }^{1} \mathrm{H}$ NMR $(600 \mathrm{MHz}$, DMSO-d 6 )

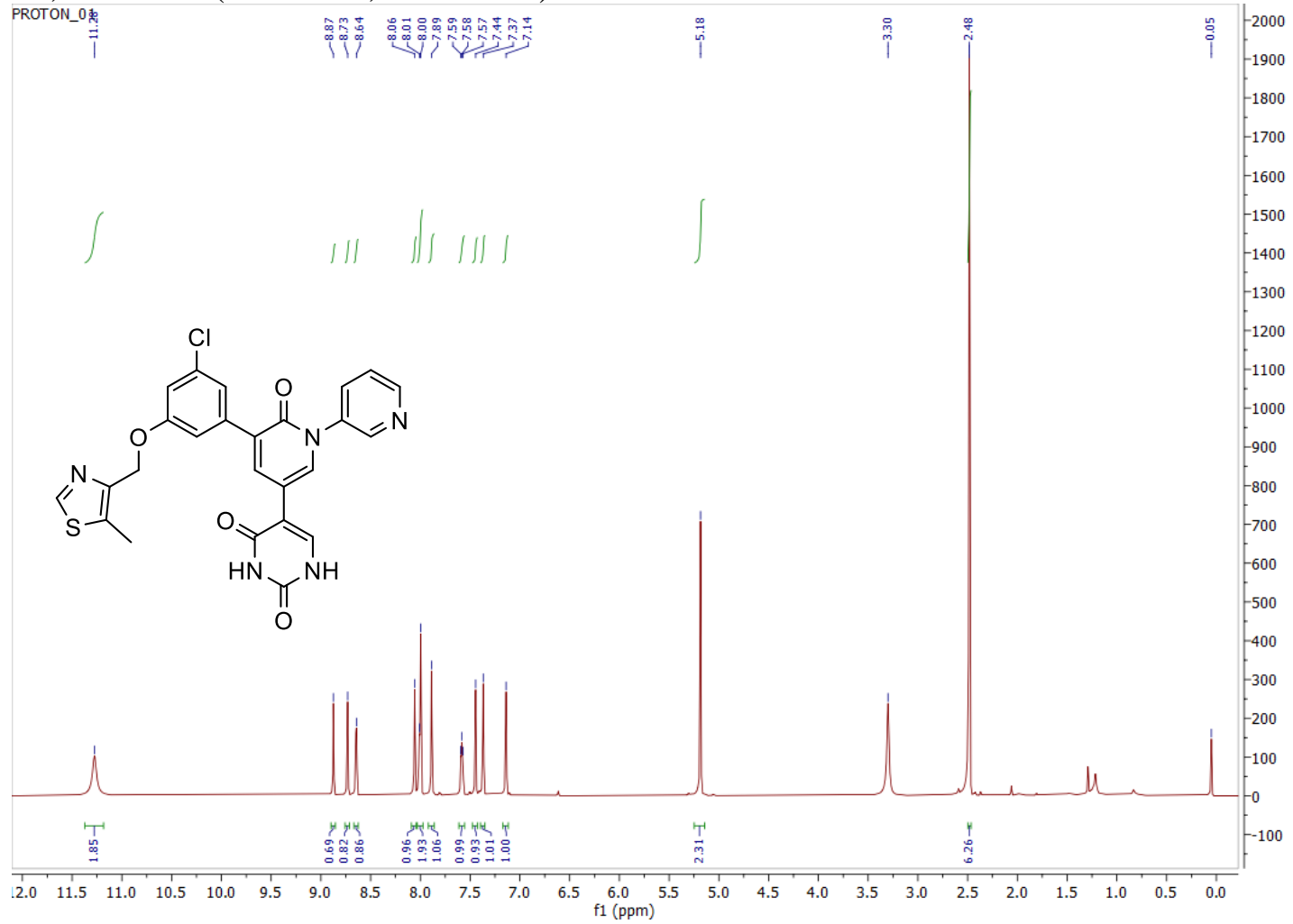

13, ${ }^{13} \mathrm{C}$ NMR (151 MHz, DMSO- $\left.d_{6}\right)$

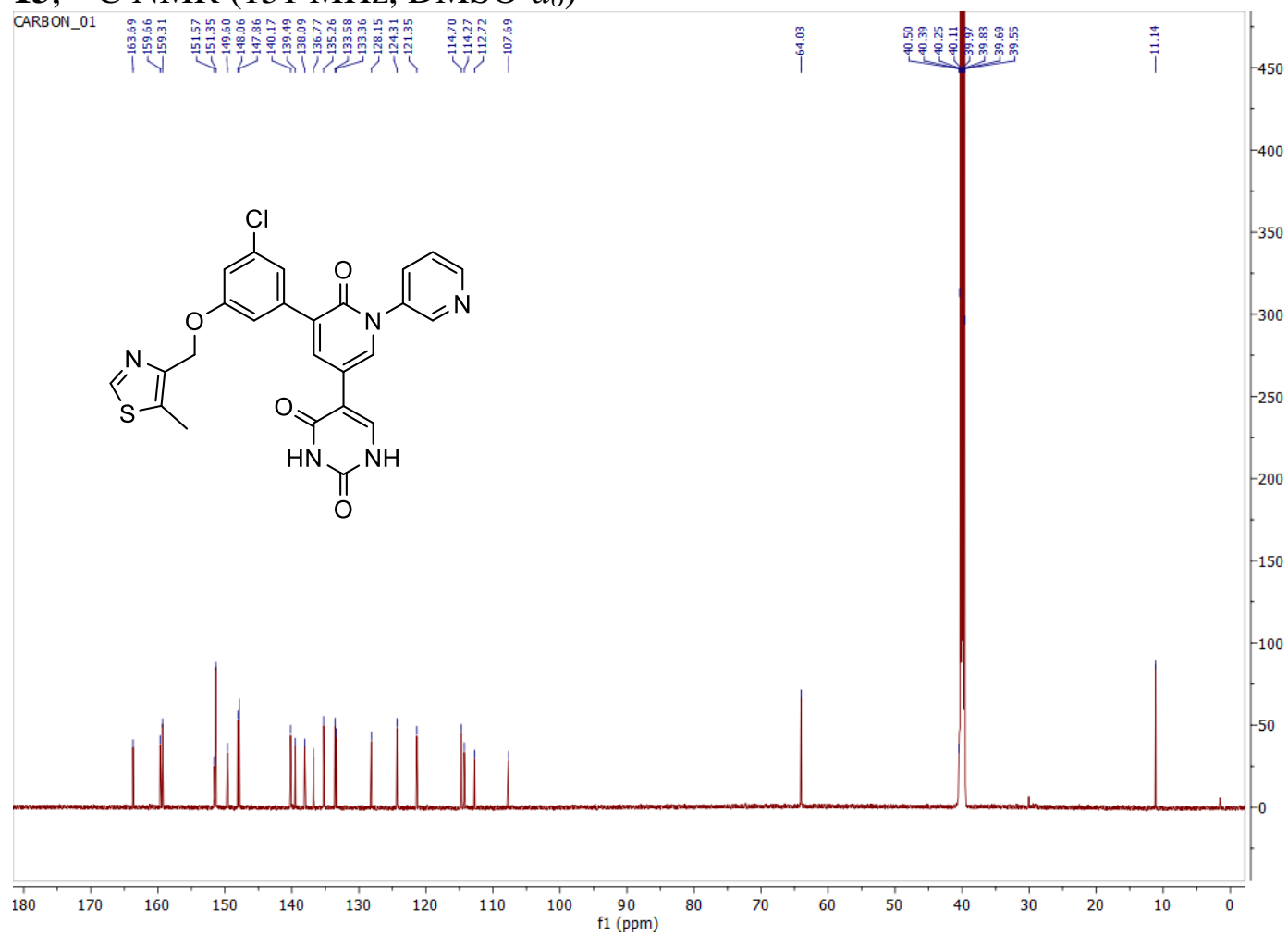


14, ${ }^{1} \mathrm{H}$ NMR (600 MHz, DMSO- $\left.d_{6}\right)$

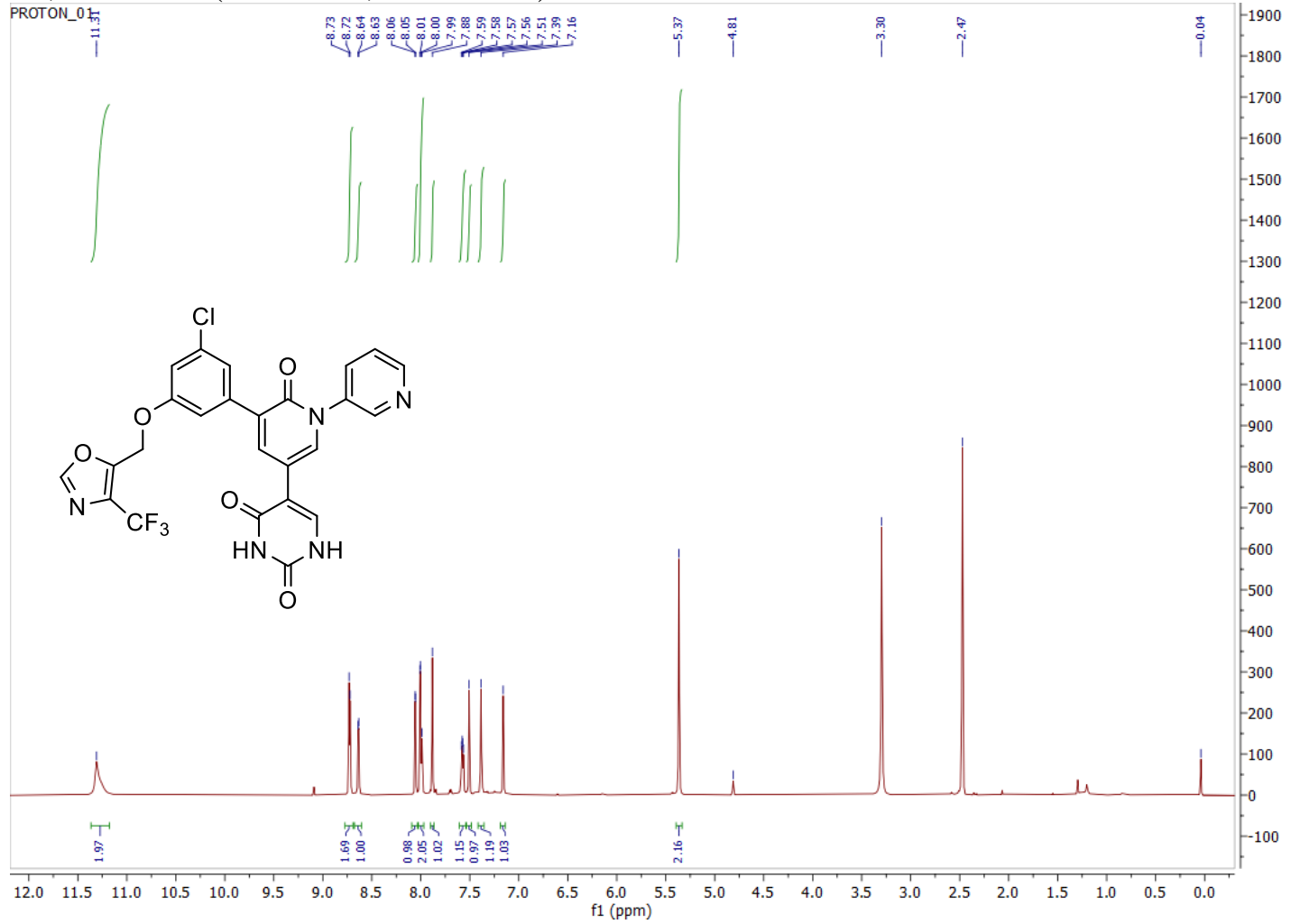

14, ${ }^{13} \mathrm{C}$ NMR $(151 \mathrm{MHz}$, DMSO-d 6 )

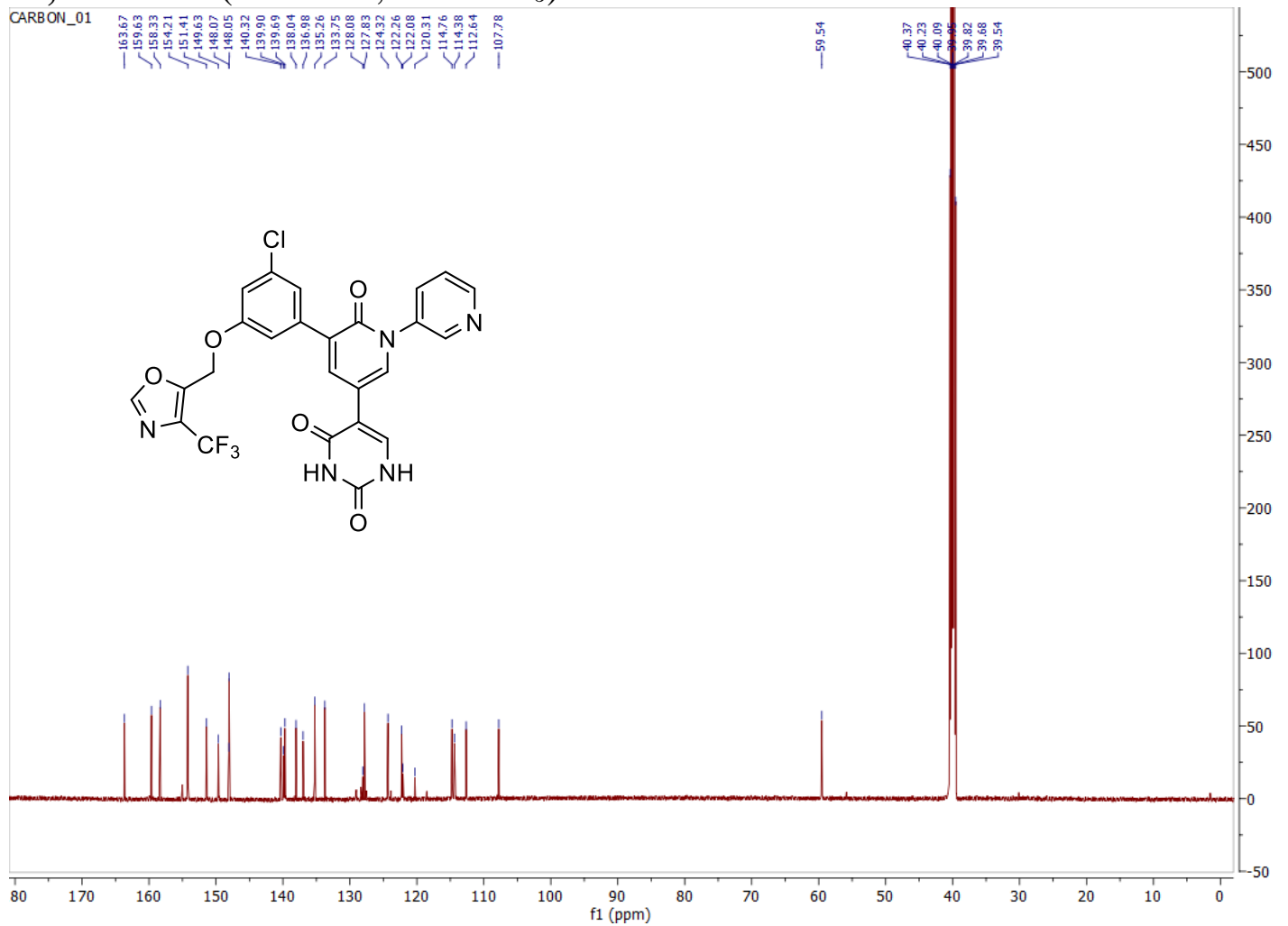


14, ${ }^{19} \mathrm{~F}$ NMR (376 MHz, DMSO)

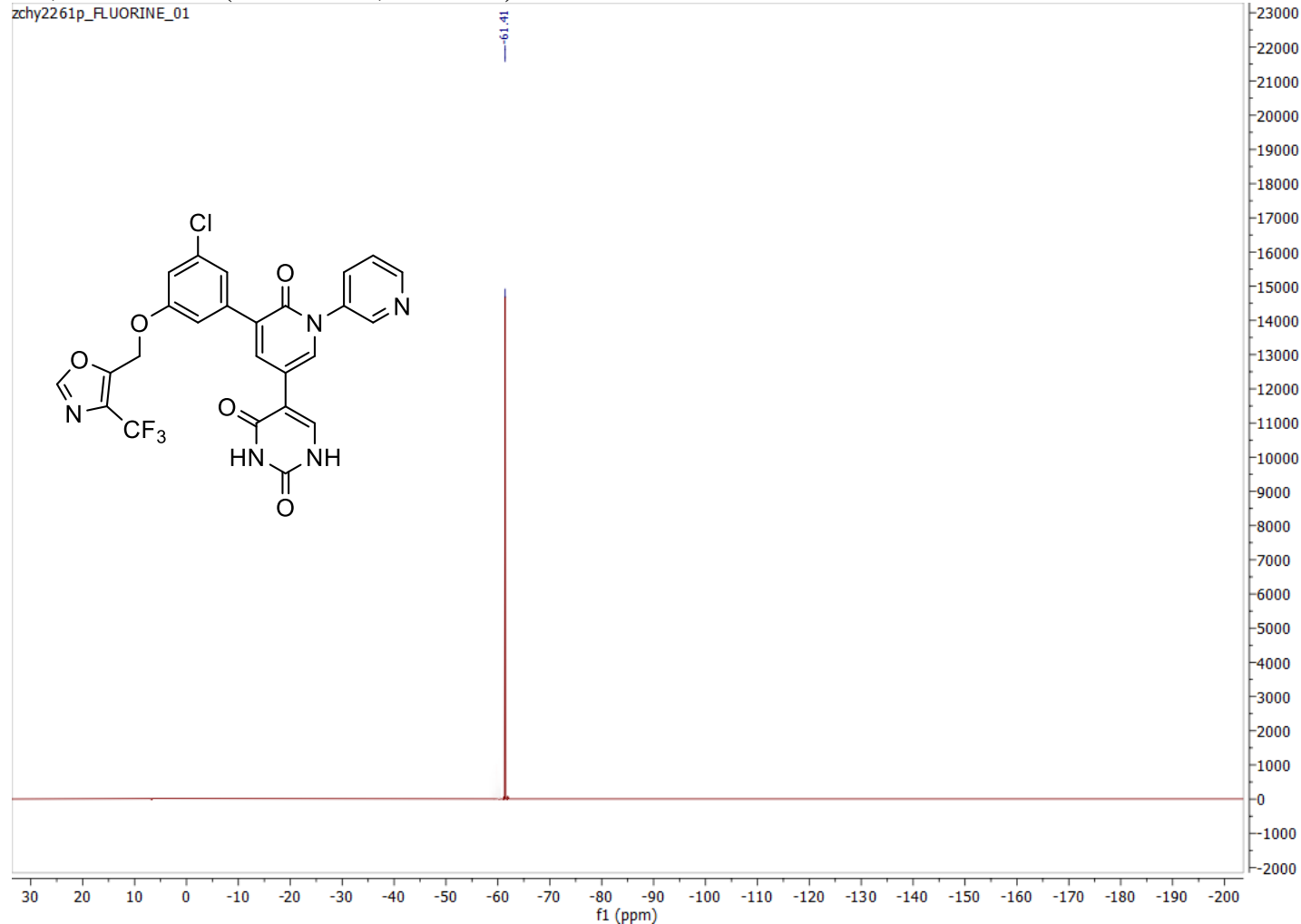

15, ${ }^{1} \mathrm{H}$ NMR (600 MHz, DMSO-d $)$

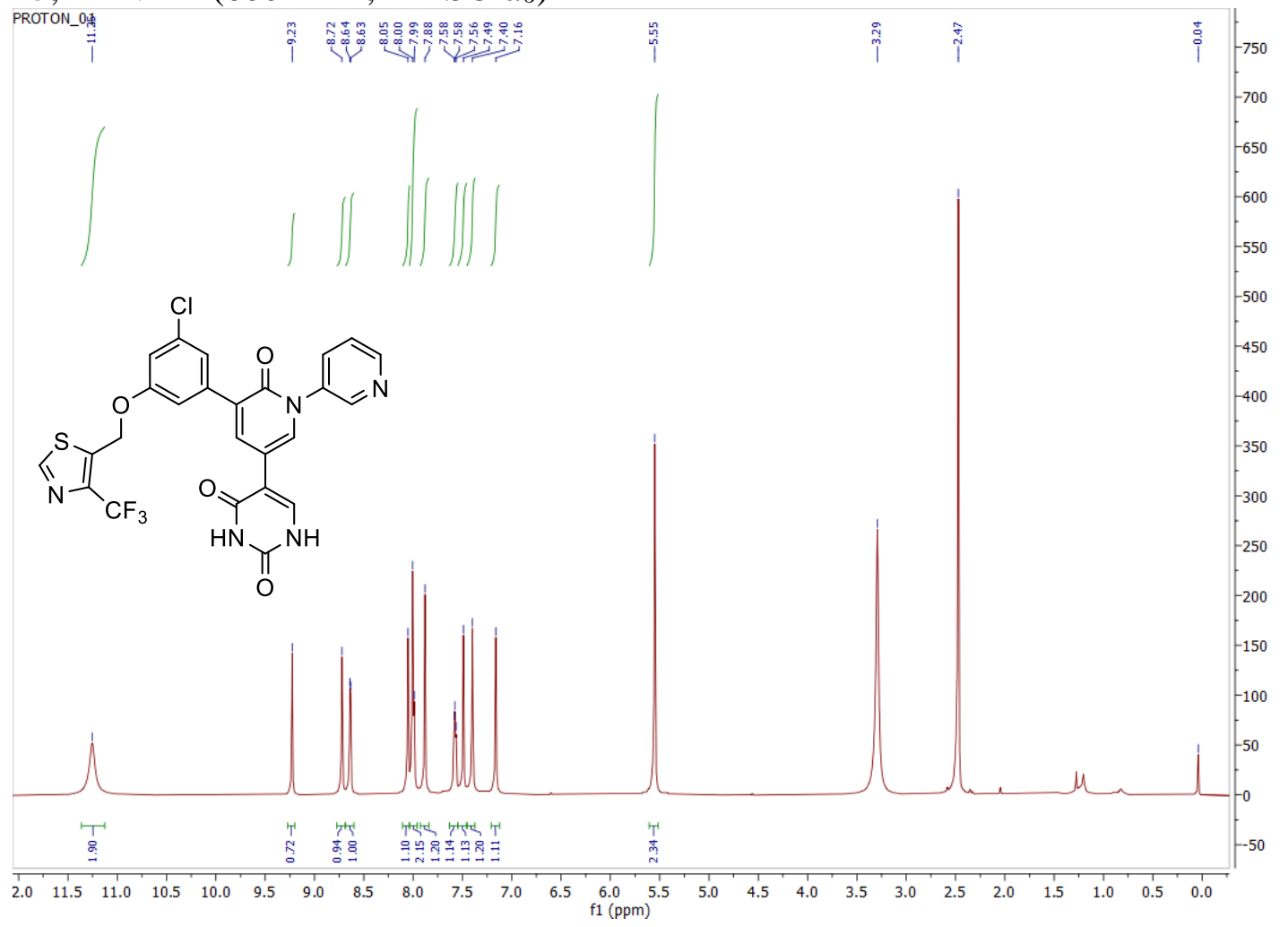


15, ${ }^{13} \mathrm{C}$ NMR $\left(151 \mathrm{MHz}, \mathrm{DMSO}-d_{6}\right)$

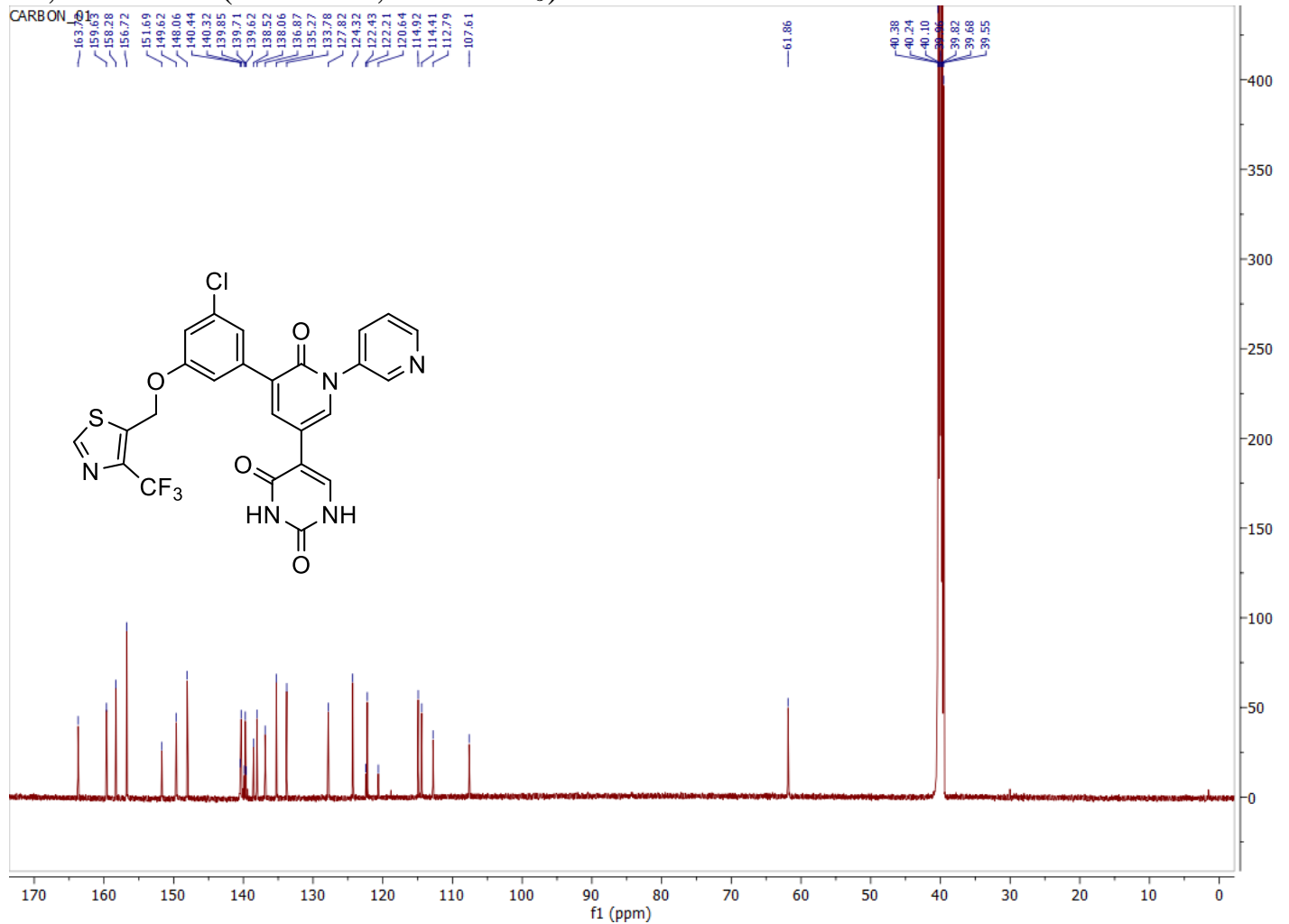

$\underset{\text { zchy2259___UUORINE_01 }}{\text { 15, }}{ }^{19}$ F NMR $(376 \mathrm{MHz}, \mathrm{DMSO})$ zchy2259p_RUORINE_01<smiles>O=c1[nH]cc(-c2cc(-c3cc(Cl)cc(OCc4scnc4C(F)(F)F)c3)c(=O)n(-c3cccnc3)c2)c(=O)[nH]1</smiles>

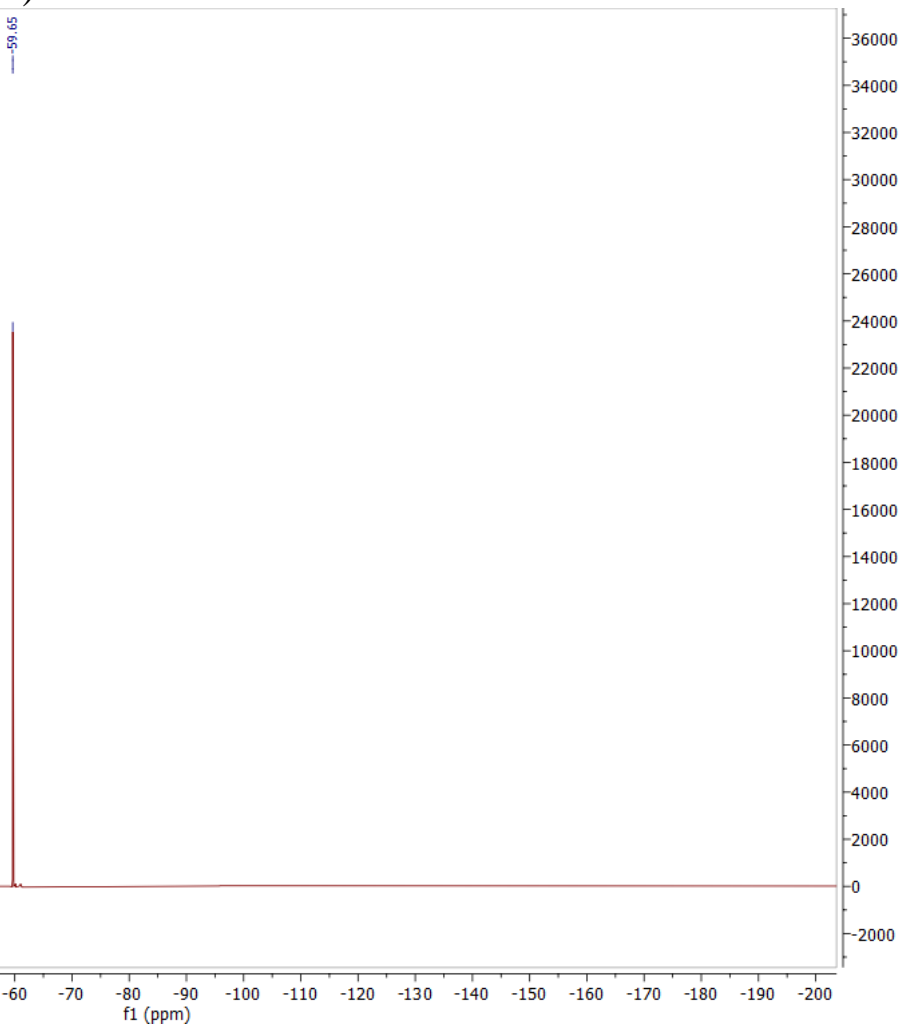


16, ${ }^{1} \mathrm{H}$ NMR $\left(600 \mathrm{MHz}\right.$, DMSO- $\left.d_{6}\right)$

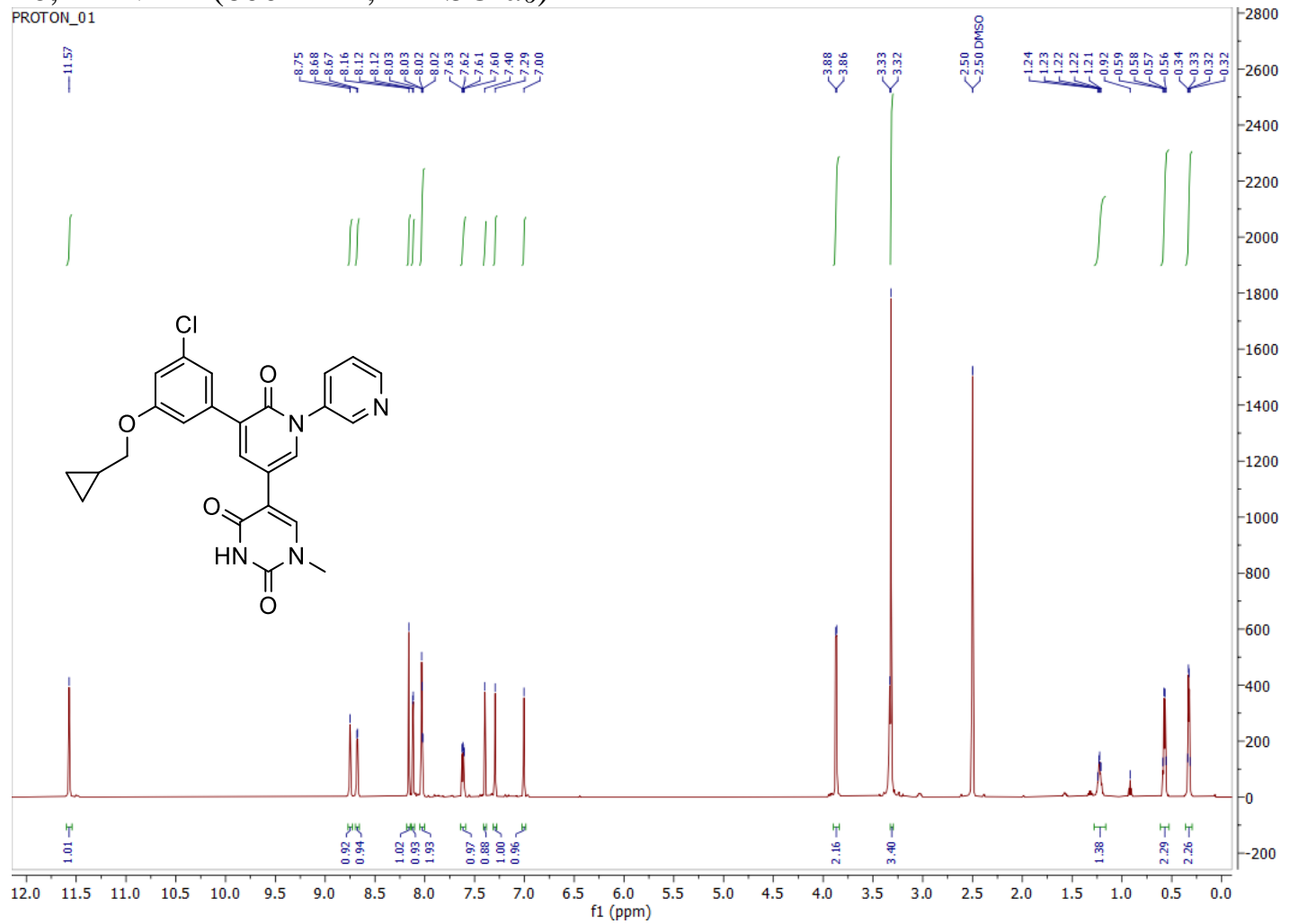

16, ${ }^{13} \mathrm{C}$ NMR $\left(151 \mathrm{MHz}\right.$, DMSO- $\left.d_{6}\right)$

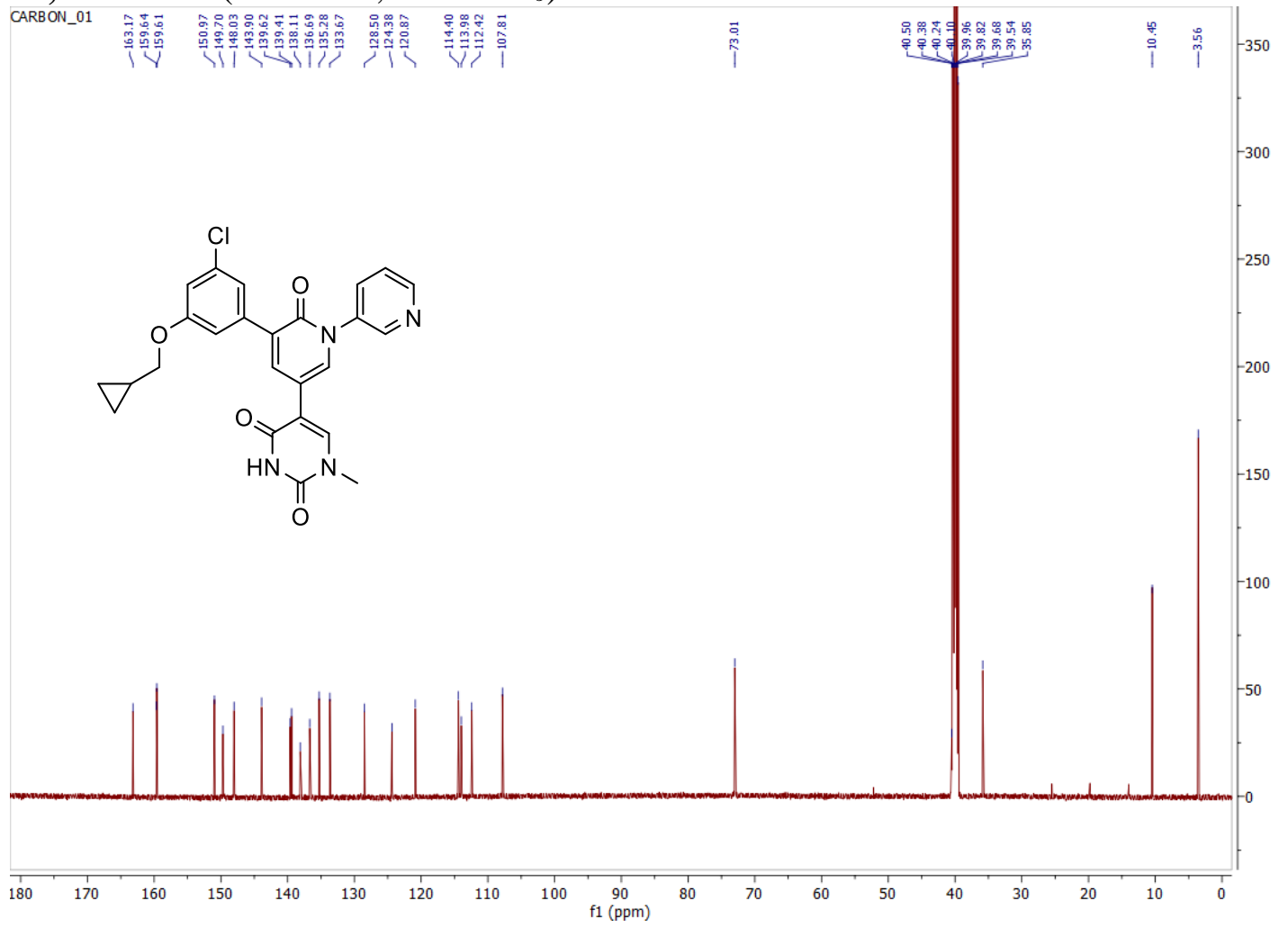


17, ${ }^{1} \mathrm{H}$ NMR $\left(600 \mathrm{MHz}\right.$, DMSO- $\left.d_{6}\right)$

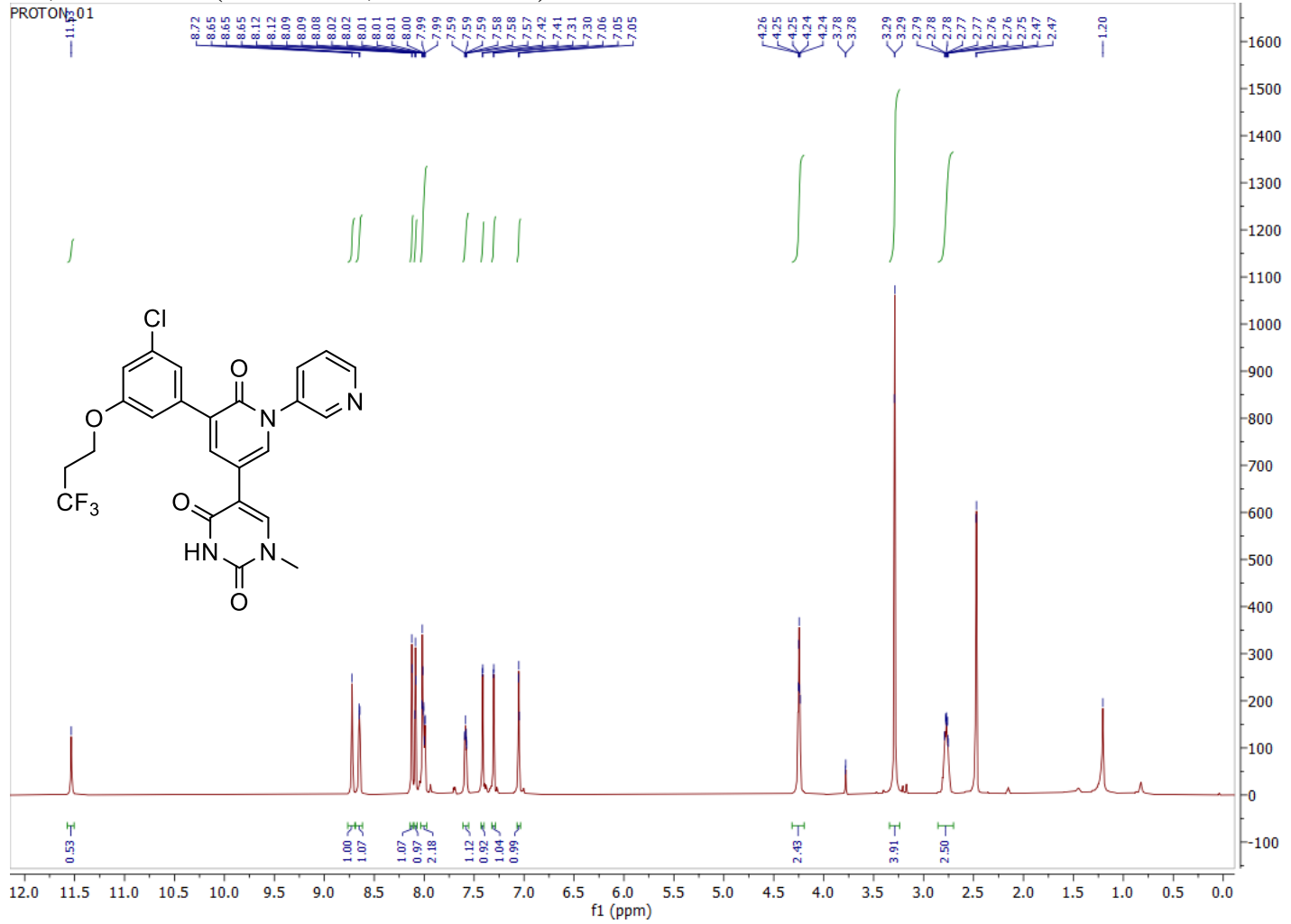

\section{7, ${ }^{13} \mathrm{C}$ NMR (151 MHz, DMSO- $\left.d_{6}\right)$}

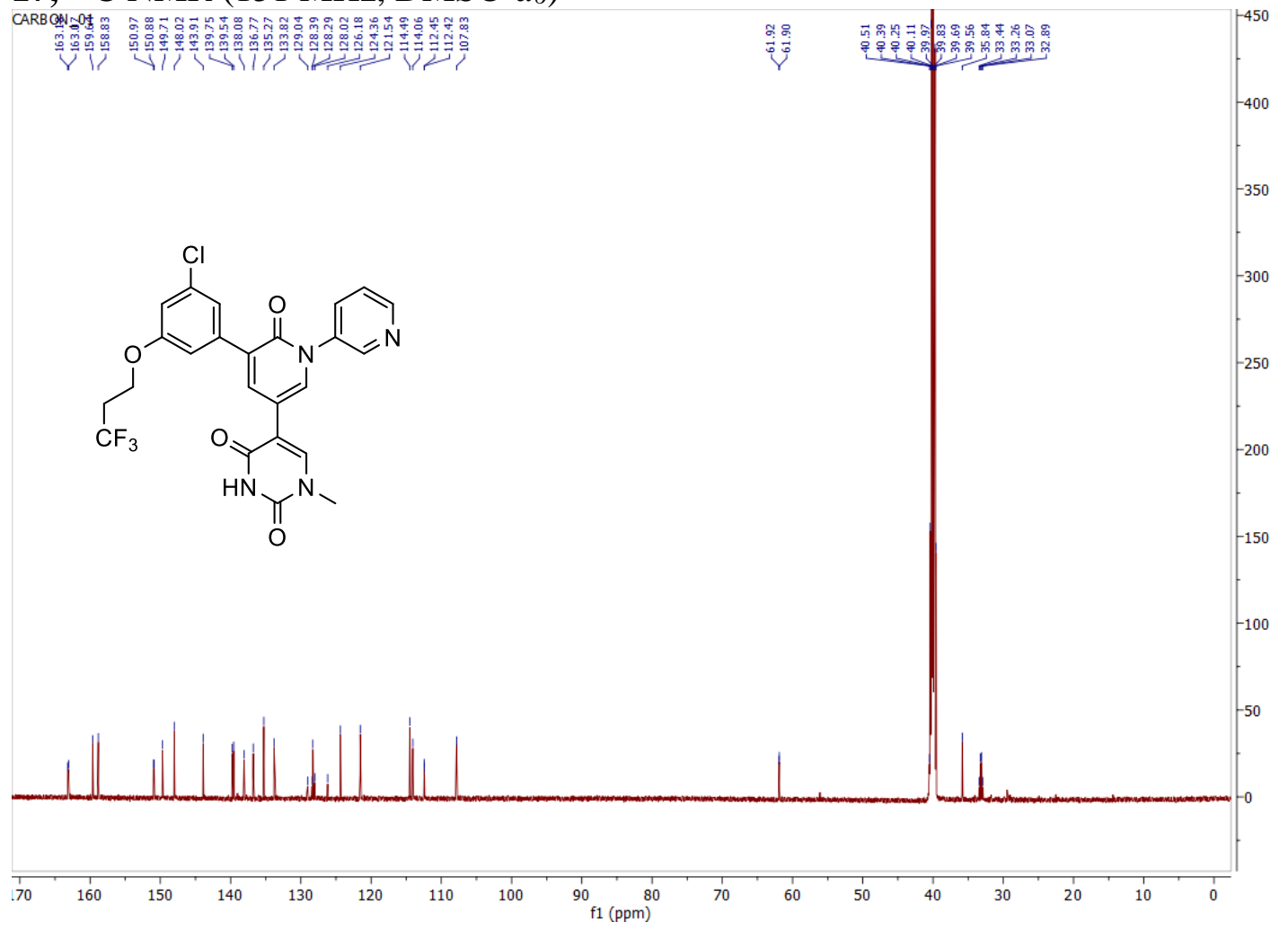


17, ${ }^{19}$ F NMR (376 MHz, DMSO)

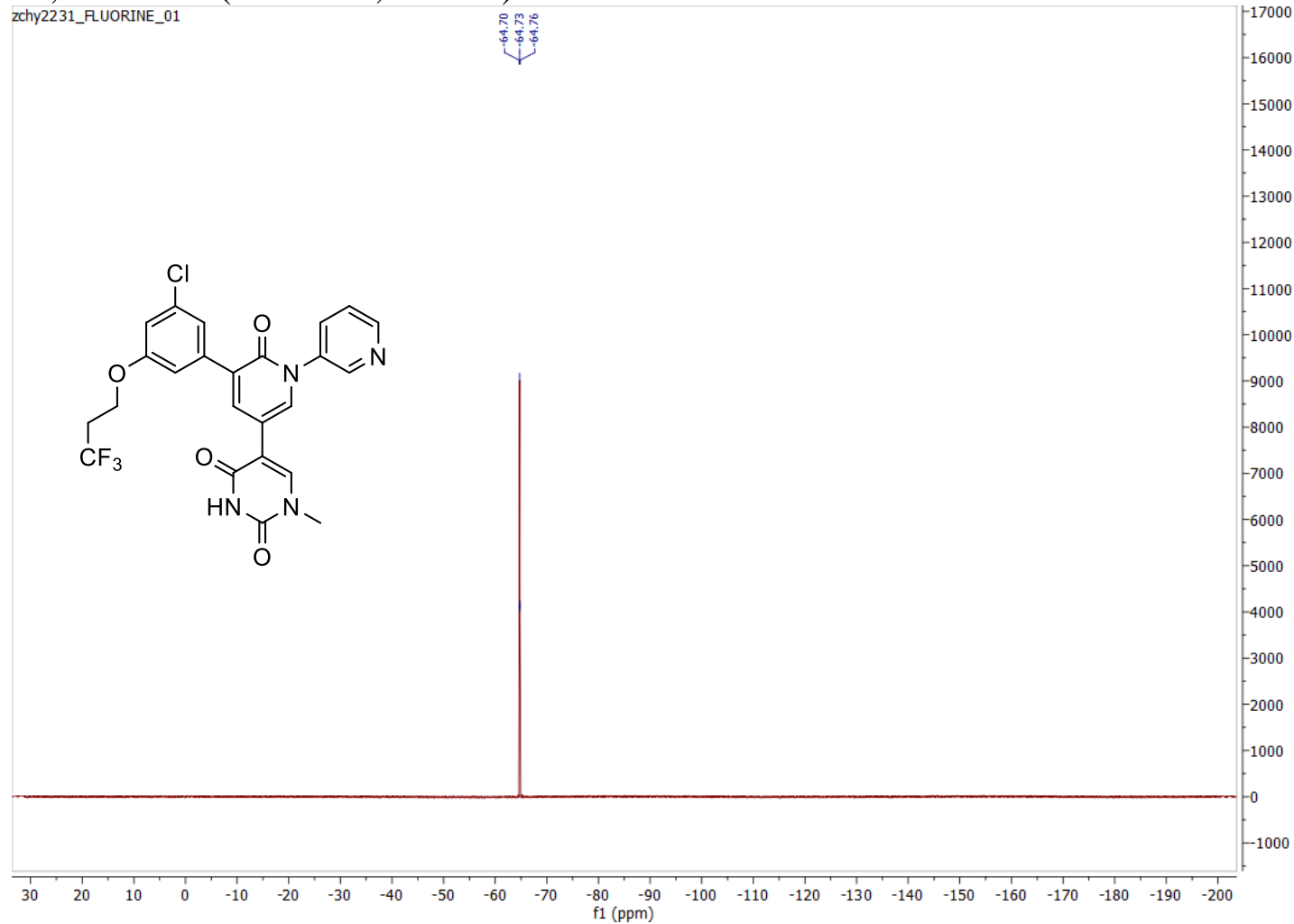

\section{8, ${ }^{1} \mathrm{H}$ NMR (600 MHz, DMSO-d $)$}

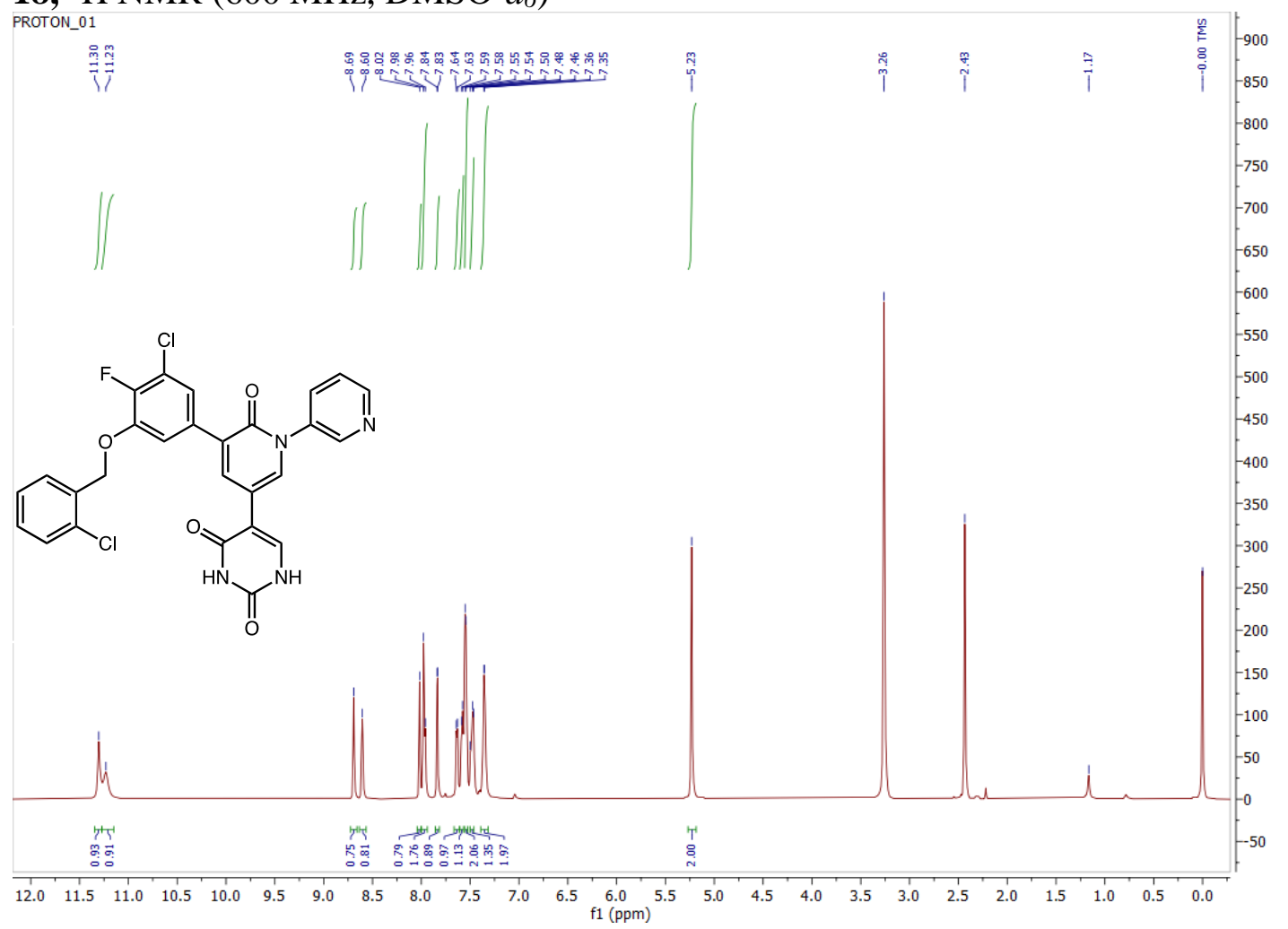


18, ${ }^{13} \mathrm{C}$ NMR (151 MHz, DMSO- $\left.d_{6}\right)$

CARBON_01

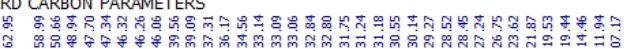

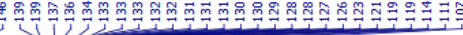<smiles>O=c1[nH]cc(-c2cc(-c3cc(Cl)c(F)c(OCc4ccccc4Cl)c3)c(=O)n(-c3cccnc3)c2)c(=O)[nH]1</smiles>
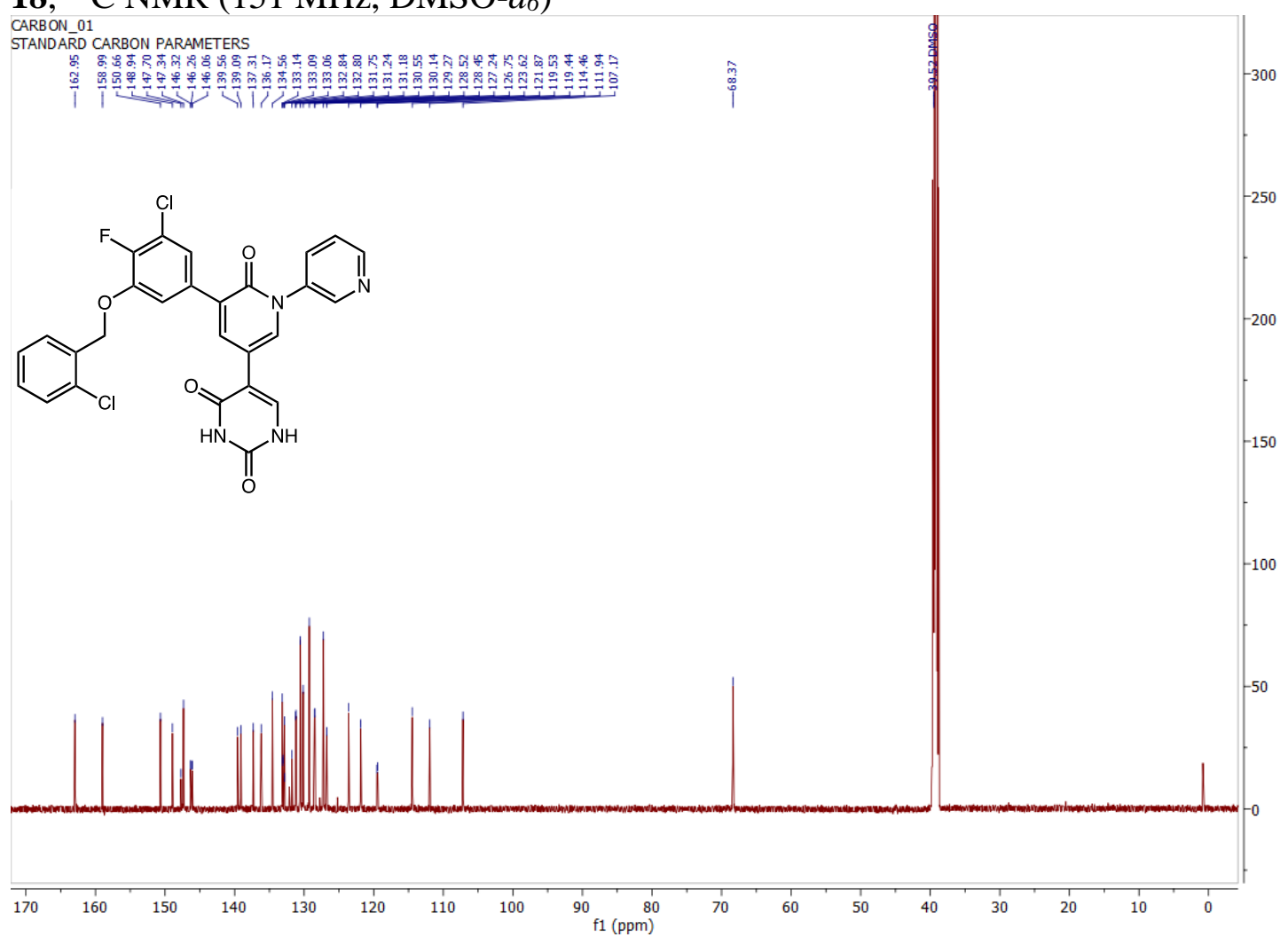

18, ${ }^{19}$ F NMR (376 MHz, DMSO)

zchy2111p-f_RUORINE_01<smiles>O=c1[nH]cc(-c2cc(-c3cc(Cl)c(F)c(OCc4ccccc4Cl)c3)c(=O)n(-c3cccnc3)c2)c(=O)[nH]1</smiles> 
19, ${ }^{1} \mathrm{H}$ NMR (600 MHz, DMSO-d 6 )

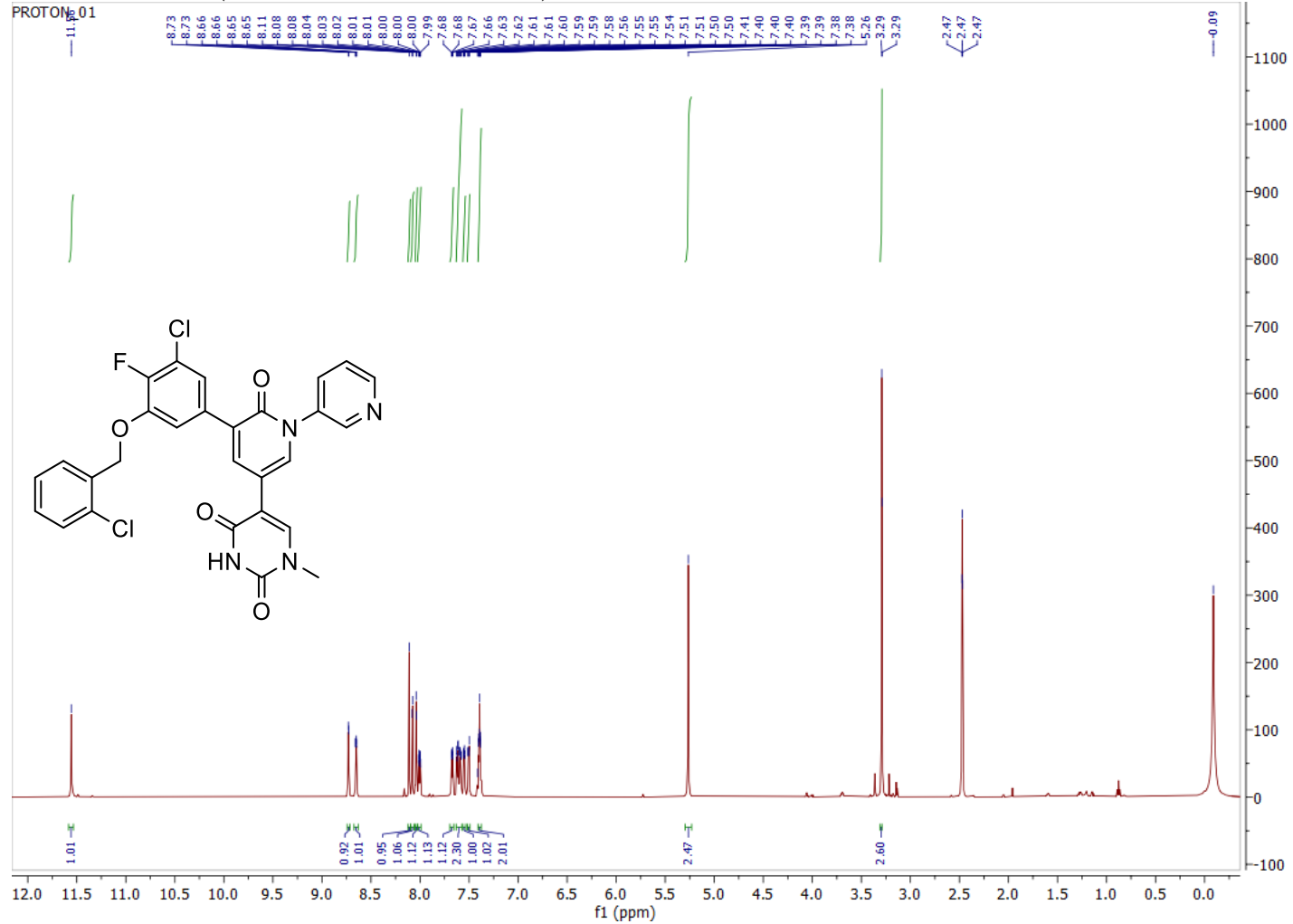

19, ${ }^{13} \mathrm{C}$ NMR (151 MHz, DMSO- $\left.d_{6}\right)$

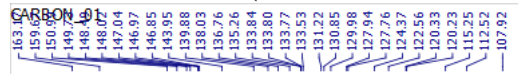<smiles>Cn1cc(-c2cc(-c3cc(Cl)c(F)c(OCc4ccccc4Cl)c3)c(=O)n(-c3cccnc3)c2)c(=O)[nH]c1=O</smiles>
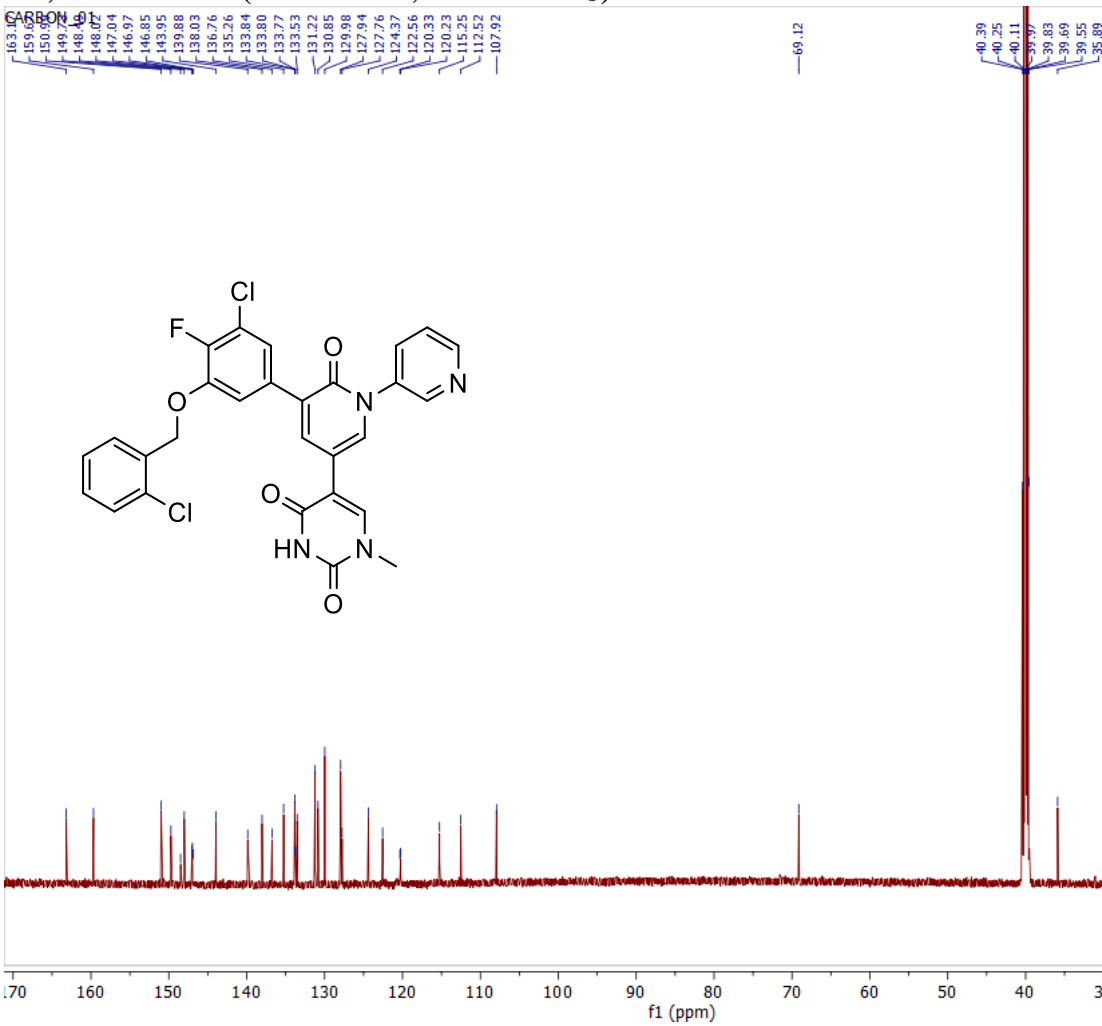
19, ${ }^{19}$ F NMR (376 MHz, DMSO)

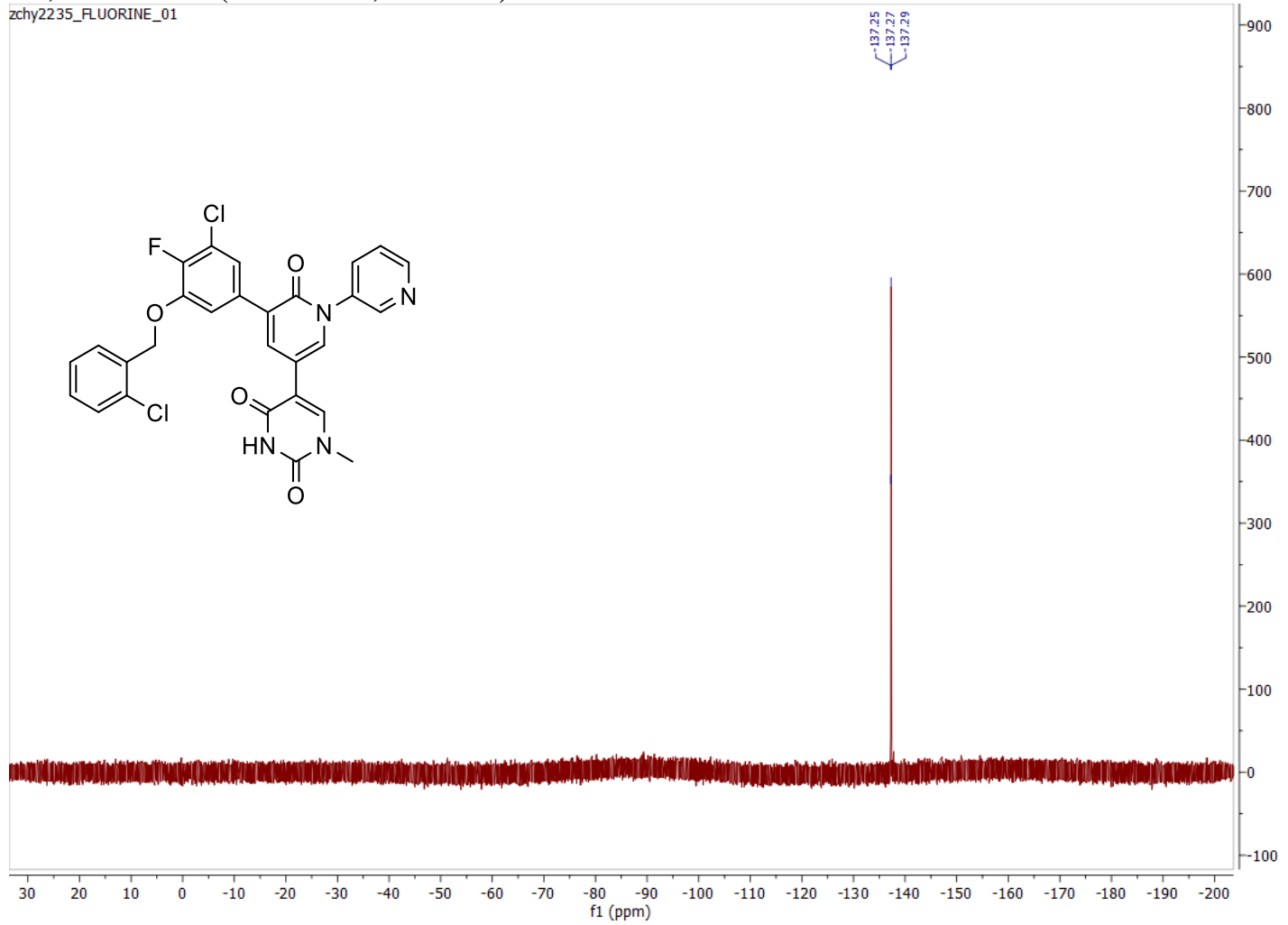

20, ${ }^{1} \mathrm{H}$ NMR (400 MHz, DMSO- $d_{6}$ )

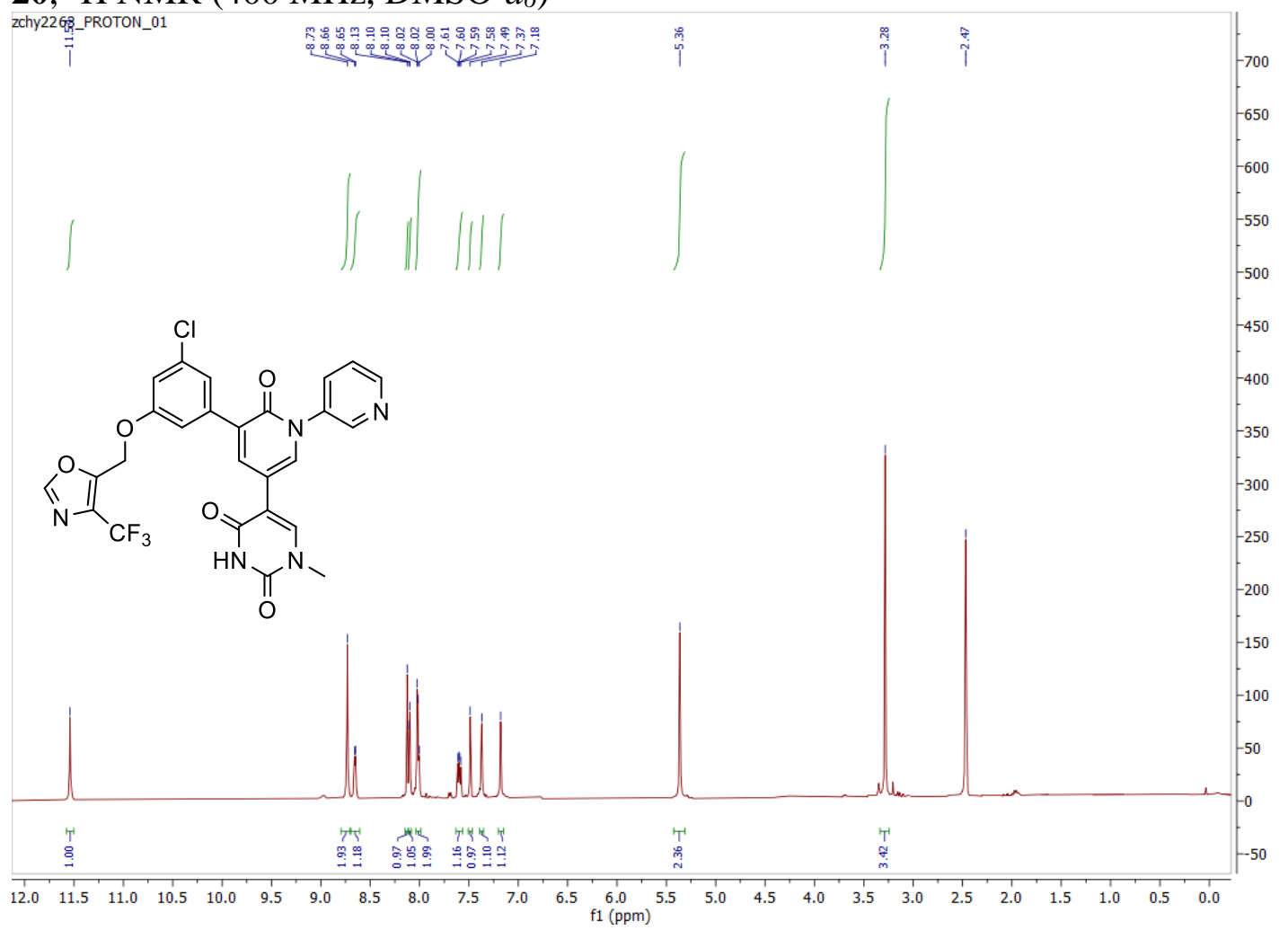


20, ${ }^{13} \mathrm{C}$ NMR $\left(101 \mathrm{MHz}, \mathrm{DMSO}-d_{6}\right)$ zchy2263_CARB ON_01

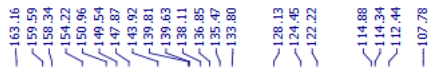<smiles></smiles>
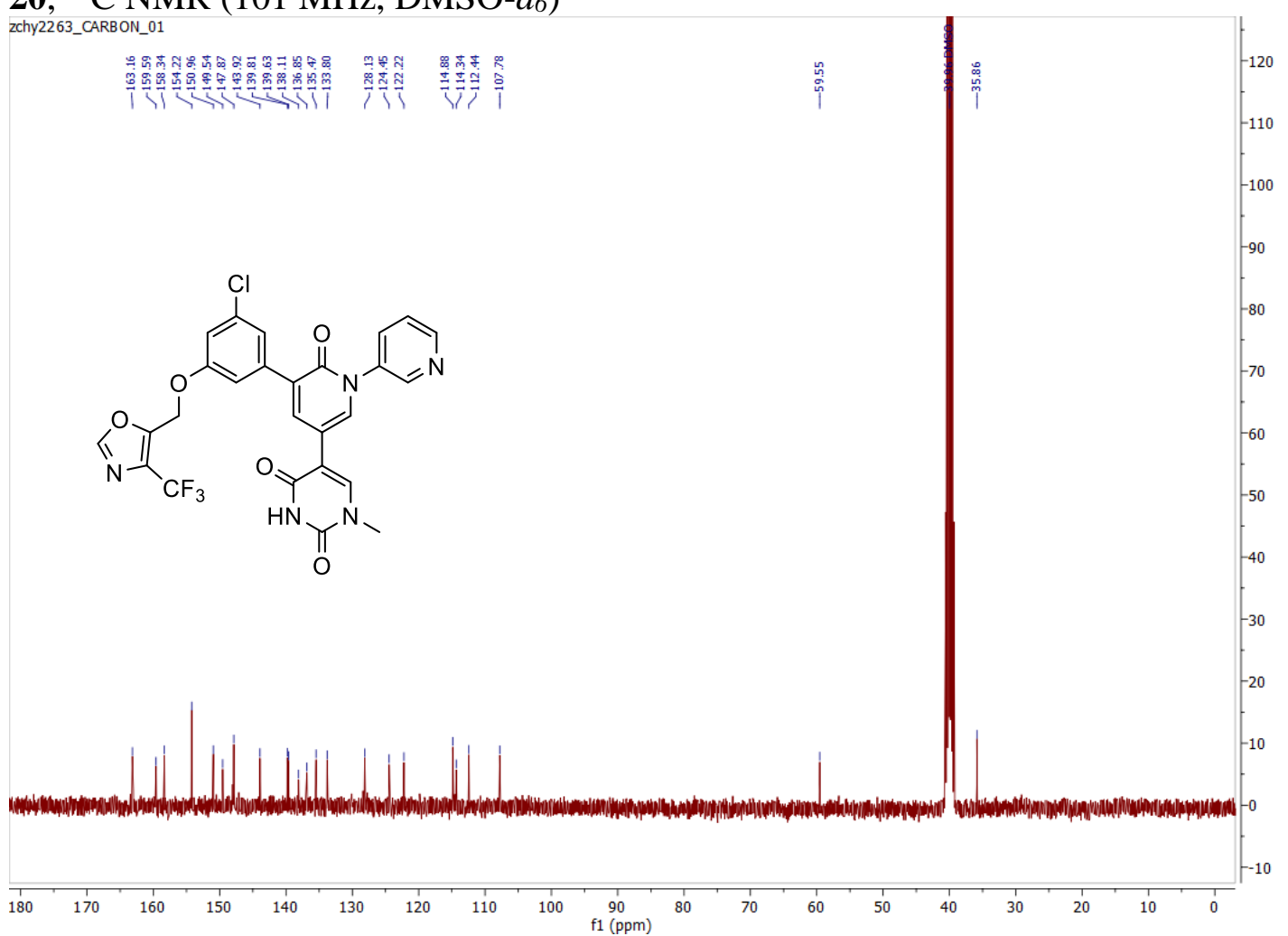

20, ${ }^{19}$ F NMR (376 MHz, DMSO)

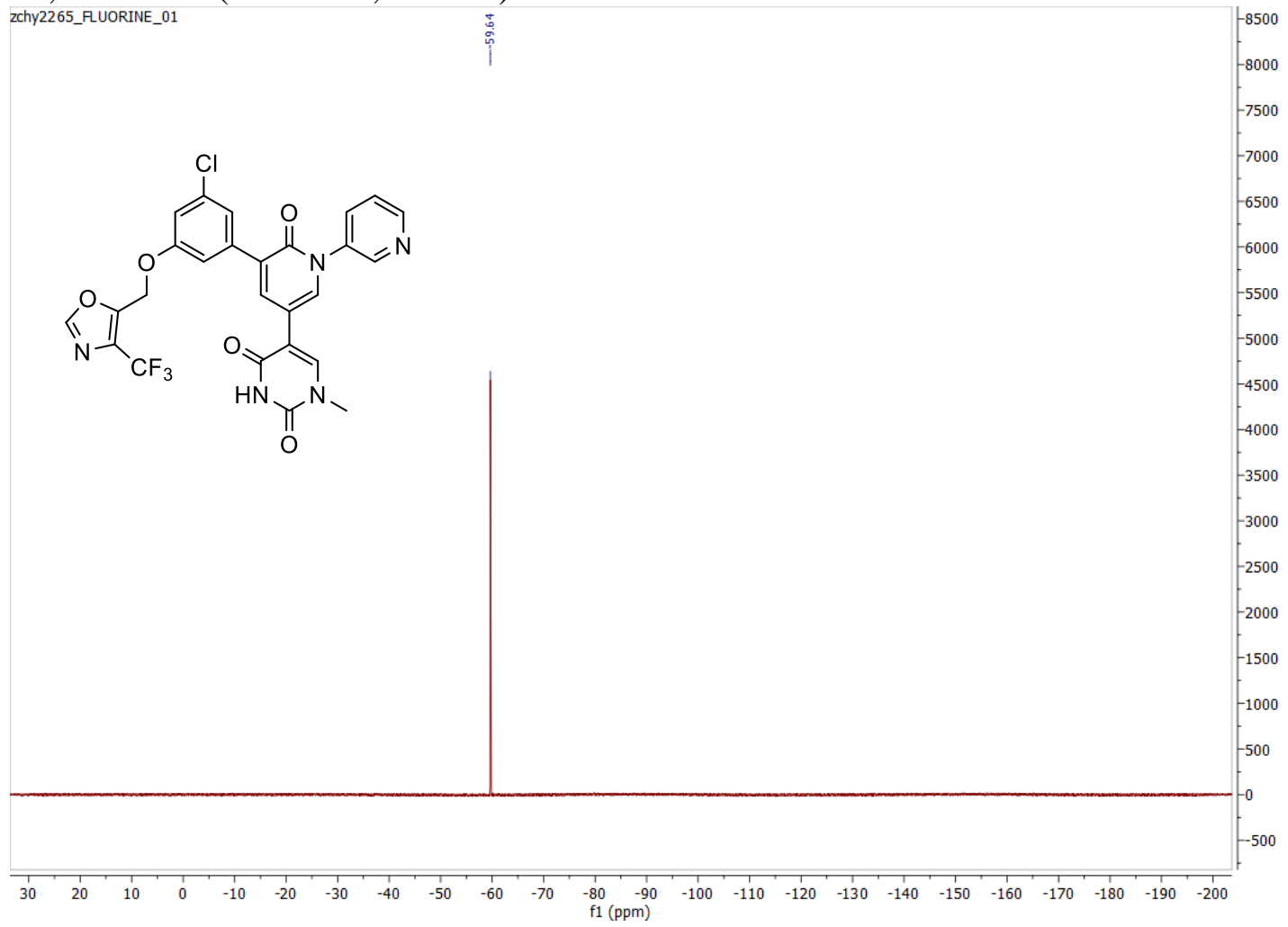


21, ${ }^{1} \mathrm{H}$ NMR $\left(600 \mathrm{MHz}\right.$, DMSO- $\left.d_{6}\right)$

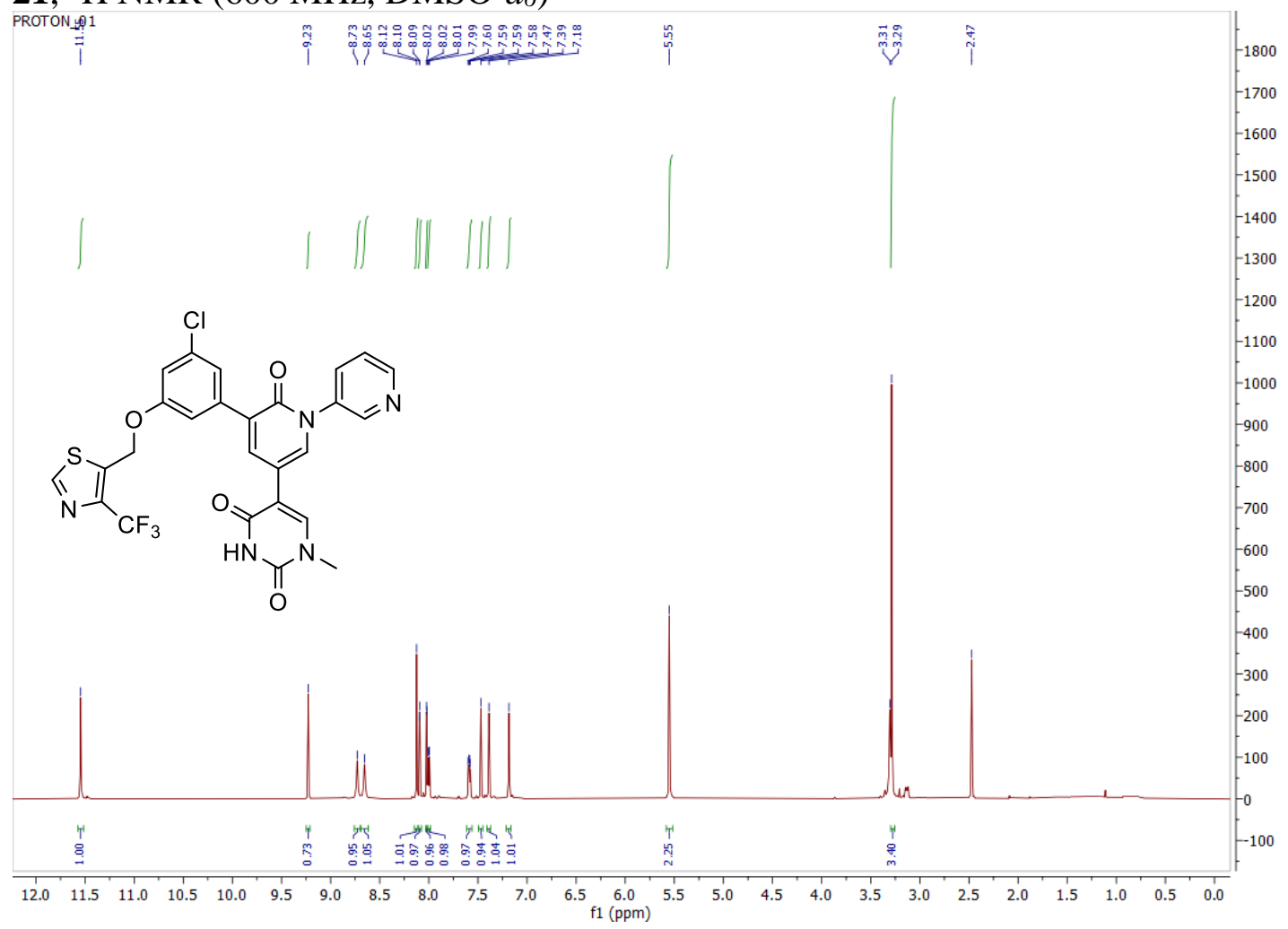

\section{1, ${ }^{13} \mathrm{C}$ NMR (151 MHz, DMSO- $d_{6}$ )}

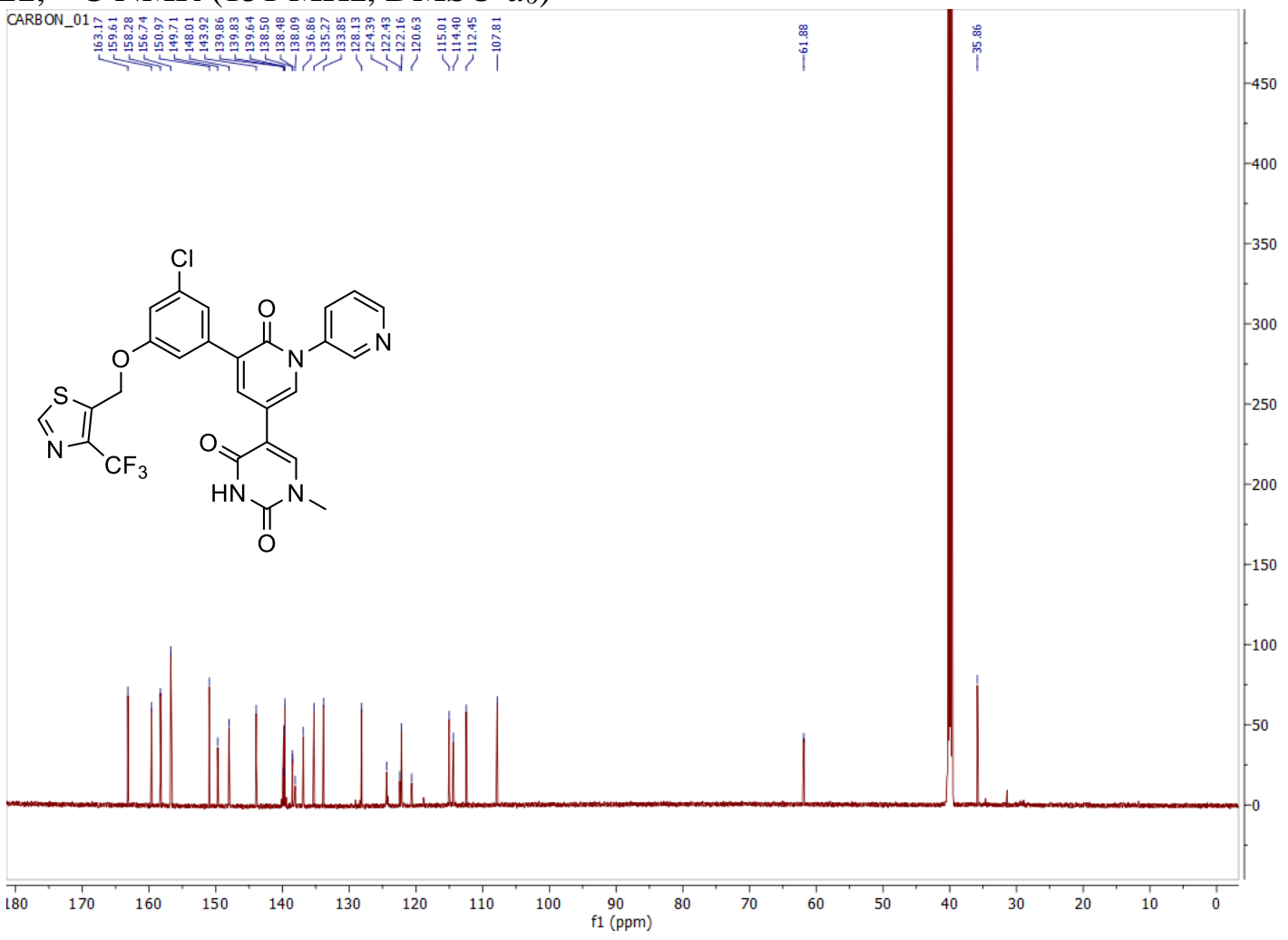


21, ${ }^{19} \mathrm{~F}$ NMR (376 MHz, DMSO)

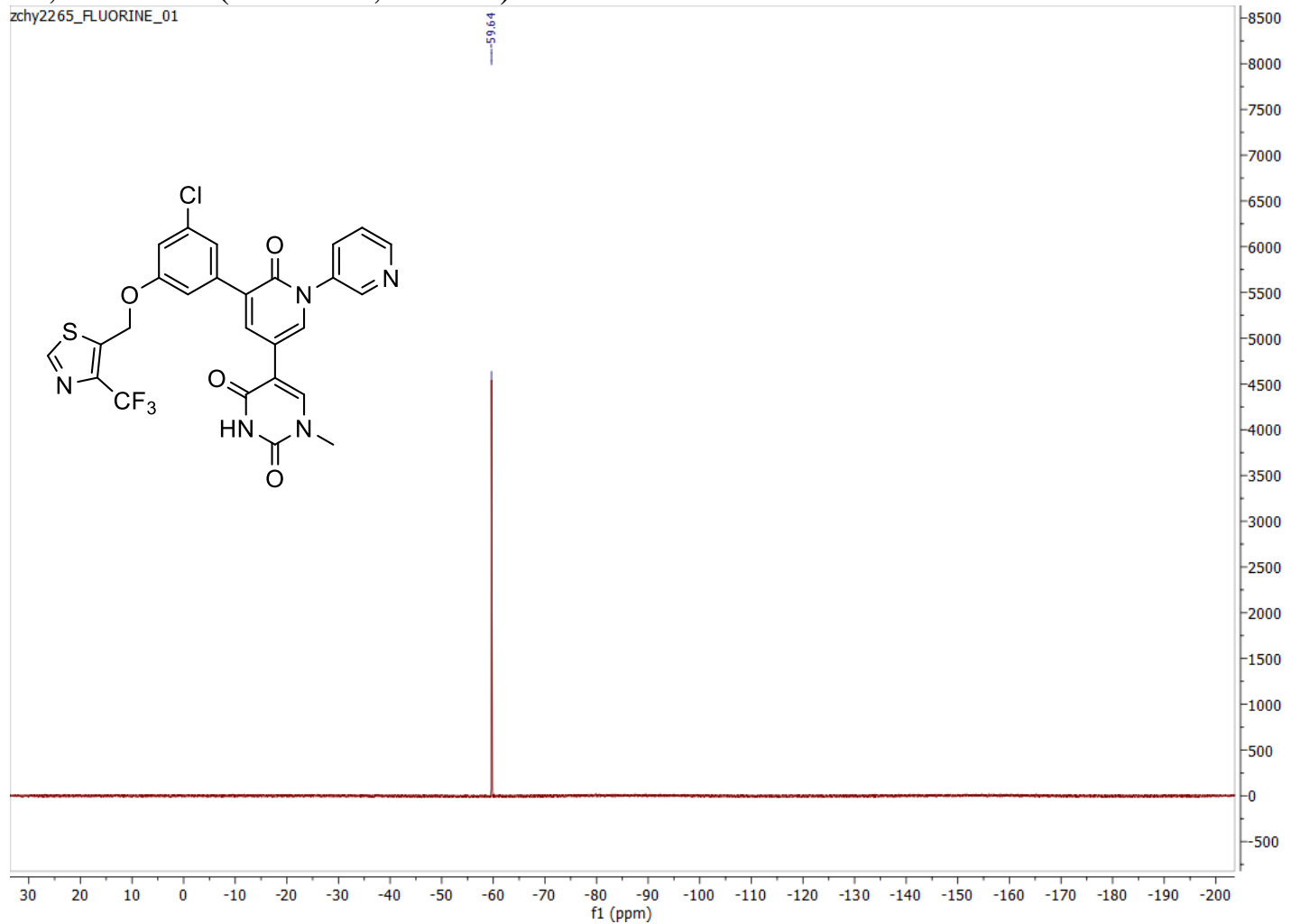




\section{References}

(1) Zhang, C.-H.; Stone, E. A.; Deshmukh, M.; Ippolito, J. A.; Ghahremanpour, M. M.; TiradoRives, J.; Spasov, K. A.; Zhang, S.; Takeo, Y.; Kudalkar, S. N.; Liang, Z.; Isaacs, F.; Lindenbach, B.; Miller, S. J.; Anderson, K. S.; Jorgensen, W. L. Potent Noncovalent Inhibitors of the Main Protease of SARS-CoV-2 from Molecular Sculpting of the Drug Perampanel Guided by Free Energy Perturbation Calculations. ACS Cent. Sci. 2021, 7, 467-475.

(2) Zhang, L.; Lin, D.; Sun, X.; Curth, U.; Drosten, C.; Sauerhering, L.; Becker, S.; Rox, K.; Hilgenfeld, R. Crystal structure of SARS-CoV-2 main protease provides a basis for design of improved $\alpha$-ketoamide inhibitors. Science 2020, 368, 409-412.

(3) Ghahremanpour, M. M.; Tirado-Rives, J.; Deshmukh, M.; Ippolito, J. A.; Zhang, C.-H.; Cabeza de Vaca, I.; Liosi, M.-E.; Anderson, K. S.; Jorgensen, W. L. Identification of 14 Known Drugs as Inhibitors of the Main Protease of SARS-CoV-2. ACS Med. Chem. Lett. 2020, 11, 2526-2533.

(4) Kabsch, W. XDS. Acta Crystallogr. D Biol. Crystallogr. 2010, 66, 125-132.

(5) McCoy, A. J.; Grosse-Kunstleve, R. W.; Adams, P. D.; Winn, M. D.; Storoni, L. C.; Read, R. J. Phaser crystallographic software. J. Appl. Crystallogr. 2007, 40, 658-674.

(6) Emsley, P.; Lohkamp, B.; Scott, W. G.; Cowtan, K. Features and development of Coot. Acta Crystallogr. D Biol. Crystallogr. 2010, 66, 486-501.

(7) Adams, P. D.; Afonine, P. V.; Bunkóczi, G.; Chen, V. B.; Davis, I. W.; Echols, N.; Headd, J. J.; Hung, L. W.; Kapral, G. J.; Grosse-Kunstleve, R. W.; McCoy, A. J.; Moriarty, N. W.; Oeffner, R.; Read, R. J.; Richardson, D. C.; Richardson, J. S.; Terwilliger, T. C.; Zwart, P. H. PHENIX: a comprehensive Python-based system for macromolecular structure solution. Acta Crystallogr. D Biol. Crystallogr. 2010, 66, 213-221.

(8) Morin, A.; Eisenbraun, B.; Key, J.; Sanschagrin, P. C.; Timony, M. A.; Ottaviano, M.; Sliz, P.. Collaboration gets the most out of software. eLife 2013, 2, e01456.

(9) Baka, E.; Comer, J. E. A; Takács-Novák, K. Study of Equilibrium Solubility Measurement by Saturation Shake-Flask Method using Hydrochlorothiaide as Model Compound. J. Pharm. Biomed. Anal. 2008, 46, 335-341.

(10) Cisneros, J. A.; Robertson, M. J.; Mercado, B. Q.; Jorgensen, W. L. Systematic Study of Effects of Structural Modifications on the Aqueous Solubility of Drug-like Molecules ACS Med. Chem. Lett. 2017, 8, 124-127.

(11) Kansy M.; Senner, F.; Gubernator, K. Physicochemical high throughput screening: parallel artificial membrane permeation assay in the description of passive absorption processes. J. Med. Chem. 1998, 41, 1007-1010. 
(12) Berben P, Bauer-Brandl A, Brandl M, Faller B, Flaten GE, Jacobsen AC, Brouwers J, Augustijns P. Drug permeability profiling using cell-free permeation tools: Overview and applications. Eu.r J. Pharm. Sci. 2018, 119, 219-233.

(13) Jorgensen, W. L. Efficient Drug Lead Discovery and Optimization. Acc. Chem. Res. 2009, 42, 724-733.

(14) Jorgensen, W. L.; Tirado-Rives, J. Molecular Modeling of Organic and Biomolecular Systems Using BOSS and MCPRO. J. Comput. Chem. 2005, 26, 1689-1700.

(15) Robertson, M. J.; Tirado-Rives, J.; Jorgensen, W. L. Improved Peptide and Protein Torsional Energetics with the OPLS-AA Force Field. J. Chem. Theory Comput. 2015, 11, 3499-3509.

(16) Jorgensen, W. L.; Tirado-Rives, J. Potential Energy Functions for Atomic-Level Simulations of Water and Organic and Biomolecular Systems. Proc. Natl. Acad. Sci. 2005, 102, 6665-6670.

(17) Dodda, L. S.; Cabeza de Vaca, I.; Tirado-Rives, J.; Jorgensen, W. L. LigParGen Web Server: An Automatic OPLS-AA Parameter Generator for Organic Ligands. Nucleic Acids Res. 2017, 45, 331-336.

(18) Jorgensen, W. L.; Chandrasekhar, J.; Madura, J. D.; Impey, R. W.; Klein, M. L. Comparison of Simple Potential Functions for Simulating Liquid Water. J. Chem. Phys. 1983, 79, 926-935.

(19) Jorgensen, W. L.; Thomas, L. L. Perspective on Free-energy Perturbation Calculations for Chemical Equilibria. J. Chem. Theory Comput. 2008, 4, 869-876. 